\title{
Bionomics and Control of the Two-Lined Spittlebug, Prosapia bicincta, on Florida Pastures and Notes on Prosapia plagiata in Costa Rica, (Homoptera: Cercopidae)
}

By

ERNEST BRAD FAGAN

\begin{abstract}
A DISSERTATION PRESENTED TO THE GRADUATE COUNCIL OF THE UNIVERSITY OF FLORIDA

IN PARTIAL FULFILLMENT OF THE REQUIREMENTS FOR THE DEGREE OF DOCTOR OF PHILOSOPHY
\end{abstract}

UNIVERSITY OF FLORIDA

1969 


\section{ACKNOWLEDGNENTS}

The writer wishes to express his appreciation to the nembers of his committee: Dr. L. C. Kuitert, Chairman; Dr. E. G. Ke1sheimer; Dr. J. E. McCaleb; and Dr. G. B. Killinger. A special debt of gratitude is extended to Dr. L. C. Kuitert for his guidance, encouragement, and invaluable assistance throughout this study. Sincere appreciation is extended to Dr. hr. G. Eden, Chairman, Department of Entomology, for his confidence, counsel, and aid on many occasions. A special expression of gratitude is extended to W. G. Genung, Everglades Experiment Station, and Dr. J. E. Miclaleb, Range Cattle Experiment Station, for advice, interest, and provision of working space at their stations. Thanks are bestored to Dr. Hugh Popenoe, Director of the Center for Tropical Agriculture, for financial assistance.

The writer gratefully acknowledges the assistance of the following: Dr. D. H. Habeck for the 1967 light trap samples and special assistance on several occasions; Dr. $\vec{F}$. W. Mear for help with the literature and taxonomic problems; Dr. S. C. Schank for supplying some grass varieties; Dr. H. A. Denmark for identification of the mites; Dr. L. R. Batre for identification of the fungus; Miss M. M. Sharpe for analys is of grass samples in Florida; Dr. Hernan Fonseca for analysis of grass samples in Costa Rica; and Dr. L. A. Hetrick for the 1966 light trap samples.

Special appreciation goes to Evaristo Morales M. and Ovicio Vargas P. for their assistance and hospitality in Costa Rica. 
Last and most, the writer's deepest gratitude goes to his wife, Jimmye Dean, for her patience and constant encouragement throughout this investigation and assistance in preparing this manuscript. 
TABLE OF CONTENTS

Page

ACKNONLEDGNENTS . . . . . . . . . . . . . . . . . . . . ii

LIST OF TABIES. . . . . . . . . . . . . . . . . . . . . vi

LIST OF FIGURES . . . . . . . . . . . . . . . . . . . . viii

IVTRODUCTION. . . . . . . . . . . . . . . . . . . . . 1

REVIEW OF THE LITERATURE. . . . . . . . . . . . . . . . . . 4

MATERIALS AND METHODS . . . . . . . . . . . . . . . 18

Rearing. . . . . . . . . . . . . . . . 18

Light Trapping... . . . . . . . . . . . . 18

Height of traps................. 20

Traps using different colored lamps . . . . . . . . 20

Periods of flight activity. . . . . . . . . . . 20

Sticky Board Traps . . . . . . . . . . . . . . . 20

Grass Varieties Trial. . . . . . . . . . . . . . . 21

Chemical Control .................... 21

1967 Experiments. . . . . . . . . . . . . 25

1968 Experiments. . . . . . . . . . . . . 26

RESULTS AND DISCUSSION. . . . . . . . . . . . . . . 28

Biology and Ecology. . . . . . . . . . . . . . 28

Eggs. . . . . . . . . . . . ....... 28

Description. . . . . . . . . . . . 28

Hatching.............. . . 28

Location .. . . . . . . . . . . . . 28

Overwintering and the effects of moisture...... . 30

Nymphs. . . . . . . . . . . . . . . . . 31

Description. . . . . . . . . . . . . 32

Duration of nymphal stages ........... . . 32

Host plants. ................ 33

Adults. . . . . . . . . . . . . . . . . . 33

Description. . . . . . . . . . . . 39

Feeding and mating habits. . . . . . . . . 39

Fecundity and longevity. . . . . . . . . . . 40

Predators and Parasites ............. . 40

Life Cycie. . . . . . . . . . . . . . . . 43

Light Trapping. . . . . . . . . . . . . . . . 44

Seascra1 distribution. ............ 44 
Effectiveness of traps at various heights. . . 46 Effectiveness of traps using different

colored lamps............ 46

Periods of flight activity . . . . . . . . 50

Effects of weather conditions on 1 ight trap

catches . . . . . . . . . . 50

Effectiveness of Colored Sticky Board Traps . . . . 55

Description of Spittlebug Injury to Pangolagrass. . . 55

Effects of Damage on Nutritive Value of Grasses . . .. 56

Economic Importance of Prosapia bicincta. . . . . 59

Light Traps .. . . . . . . . . . . . 60

Cultural Control. . . . . . . . . . . . 60

Burning. . . . . . . . . . . 61

Mowing . . . . . . . . . . . . 61

Grazing. .'. . . . . . . . . . 62

Harvesting . . . . . . . . . . 63

Renovation............ 63

Chopping and discing.......... 63

Planting time.............. 63

Grass-legume mixtures. ........... 64

Grass varieties. ............ 64

Chemical Control................ 65

1967 Experiments ........... 65

1968 Experiments ............. 69

Sunnary on chemical control......... 85

ECONOMIC IMPORTANCE, CULTURAL AND CHEMICAL CONTROL OF

Prosapia plagiata ON KIKUYUGRASS IN COSTA RICA . . . . . 91

Synonymy ....................... 91

Description. . . . . . . . . . . . . . . . . 92

Influence of Feeding on Kikuyrgrass. . . . . . . . . . 93

Materials and Methods................ 93

Results . . . . . . . . . . . . . . 95

Discussion. . . . . . . . . . . . . . 95

Economic Importance. . . . . . . . . . . . . . 97

Control. . . . . . . . . . . . . . . . . 98

Cultural Control. . . . . . . . . . . . 98

Chemical Control. . . . . . . . . . . . 98

Materials and methods. .......... . 99

Discussion and conclusions . . . . . . . 99

SUMMARY . . . . . . . . . . . . . . . . 104

LITERATURE CITED. . . . . . . . . . . . . . . 108

ADDITIONAI REFERENCES . . . . . . . . . . . . . . 114

BIOGRAPHICAL SHETCH . . . . . . . . . . . . 116 
LIST OF TABLES

Table

Page

1 Head capsule and mesothoracic wing pad measurements (in $\mathrm{mm}$ ) of the nymphal instars of Prosapia bicincta in Florida. . . . . . . . . . 36

2 Host 1 ist of $P$. bicincta nymphs in Florida. . . . . . . 37

3 Effectiveness of blacklight traps placed with their lamps centered at various heights above the ground for attracting P. bicincta. . . . . . . . . 49

4 Effectiveness of colored fluorescent lamps in attracting $\mathrm{P}$. bicincta to light traps ......... . 51

5 Percentages of $P$. bicincta trapped per hour in nine nights.................. 52

6 Effectiveness of different colored sticky board traps for attracting male and female $\mathrm{P}$. bicincta. . . . . . 57

7 Effects of damage by adult $P$. bicincta on the nutritive value of pangolagrass and bermudagrass. . . . 58

8 Visual rating of damage to grasses by $P$. bicincta in a field trial...................

9 Chemical control of the first generation nymphs. Experiment 1, 1967............... 67

10 Effects of mowing and insecticide treatments on nymphs. Experiment 2, 1967................. 68

11 Control of adults with azinphosmethy1. Experiment 3, 1967....................... 70

12 Control of rymphs with experimental insecticides.

Experiment 4, 1967............... 71

13 Control of adults with experimental insecticides.

Experiment 4, 1967. . . . . . . . . . . . . 72

14 Control of aduits with phorate. Experiment 1, 1968 . . 73 
15 Control of nymphs with phorate. Experiment 1, 1968. . 74

16 Control of $\mathrm{P}$. bicincta with naterials cleared for use on pastūres and vegetables. Experiment 2, 1968. . 76

17 Control of adults with experimental insecticides on St. Augustinegrass. Experiment 3, 1968. . . . . . 79

18 Control of nymphs with experimental insecticides in Belle Glade. Experiment 3, 1968 .......... 80

19 Control of nymphs with experimental insecticides on pangolagrass. Experiment 4, 1968.......... 82

20 Effectiveness of experimenta1 insecticides for protecting grasses from damage by $\mathrm{P}$. bicincta...... 83

21 Control of nymphs with experimental systemic insecticides. Experiment 5, 1958. . . . . . . . 86

22 Effectiveness of experimental systemic insecticides in protecting grasses from damage by $\mathrm{P}$. bicincta. . . . . 87

23 Effects of $\mathrm{P}$. plagiata feeding on nutritive value of

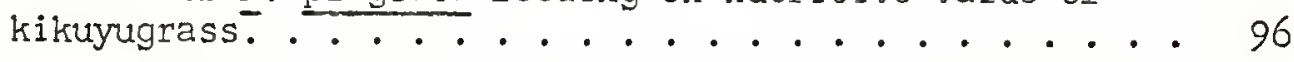

24 Chemical control of P. plagiata nymphs. Costa Rica, 1967 ............................ 101 


\section{LIST OF FIGURES}

Figure

Page

1 Female two-lined spittlebugs caged on grass inserted their eggs into moist filter paper wrapped around the grass. . . . . . . . . . . . . . . .

2 Iight trap, which divided the catch into hourly samples, used to determine periods of two-lined spittlebug activity. . . . . . . . . . . . .

3 Gasoline powered knapsack blower used to apply materials in the chemical control experiments. . . . 23

4 Development of Prosapia bicincta eggs. . . . . . . 29

5 The nymphal instars of $\underline{\text { P bicincta }}$. . . . . . . 34

6 Variations in the color markings of $P$. bicincta adults............................ 41

7 Weekly occurrence of $P$. bicincta in light trap catches for three year̃s at Gainesville, Florida. . . . 45

8 Average weekly occurrence of $\underline{P}$. bicincta in blacklight traps at the Range Cattle Expēriment Station, Ona,

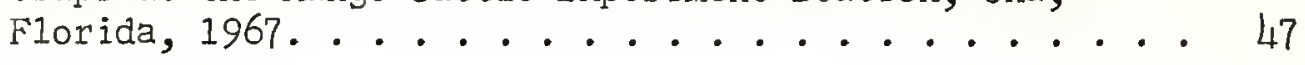

9 Average weekly occurrence of male and female $\underline{P}$. bicincta in light trap catches at Gainesville, Florida, 1967..................... 48

10 Percentages of male and female $\mathrm{P}$. bicincta trapped per hour in five nights. . . . . . . . . . . 53

11 Effect of the minimum temperature on nightly light trap catches of $\mathrm{P}$. bicincta in September...... . 54

1.2 Male and fenzle P. plagiata. . . . . . . . . 94

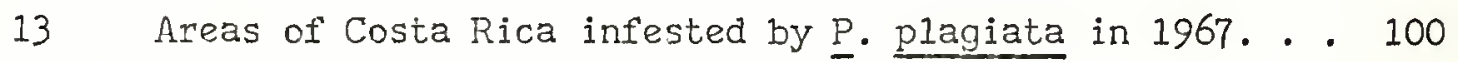




\section{INTRODUCTION}

About thirty years ago Herbert Osborn (48) stated in his ciassical work on "Pasture and Forage Insects" that: "The immense place of grass and other forage crops in our system of agriculture is possibly hardly realized because of the more tangible results and available figures appear in other products."

To a great extent, this statement is still true today. Taken in the broadest sense, the grass family from which come rice, wheat, corn, sugarcane, and many other crops is the most important group of plants in agriculture. But the grass and forage that Professor Osborn was referring to is that on which the livestock industry is based.

In Florida alone the dairy and beef industries are worth $\$ 87,200,000$ and $\$ 69,000,000$ per year, respectively (89). When the figures for the sheep, horse, and swine industries, which are also more or less based on grass, are added, the importance of pastures and forages becoines additionally significant. Therefore any circumstances adversely affecting the production of grass results in economic loss to the grower.

Many insects are associated with pasture grasses and a few are recognized as economic pests. During outbreak years the two-lined spittlebug, Prosepia bicincta (Say), is an economic pest and is capable of top killing entire pastures trrough the injection of phytotoxic salivary substances while feeding. The two-lined spittlebug is a native of Florida but has only been reponted as a pest since 1954. Why has this insect become eco- 
nomically important only in the last 15 years?

The answer undoubtedly lies in the fact that prior to 1935 less tinan $1,000,000$ acres in Florida wert in improved grass pastures. Then in 1943, three new grasses, Pensacola bahiagrass, pangolagrass, and Coastal bermudagrass were released. Since then more and more land has been developed as improved pastures which are characterized by the use of intensive agronomic practices and regular fertilization. By 1960, Florida had over 8,000,000 acres or about $\frac{1}{4}$ of all usable land in pastures with $2,610,536$ acres in improved pastures. Approximately 750,000 additional acres are predicted by $1975(89)$.

Unfortunately, supplanting the native range with lush, nutritious grasses is extremely favorable for pasture-infesting insects. Pasture improvement tends to produce a stable monocultural environment which is optimum for insects associated with grass. Consequently the two-lined spittlebug, which had been innocuously associated with grass for years, suddenly exhibited an unsuspected potential as an economic pest of improved pasture grasses. This problem is certainly not confined to Florida. In recent years, damage to improved pastures had been reported throughout the southeast United States. Concurrently closely related species have been reported damaging improved pastures throughout the Caribbean and Central and South America. Because of the relatively recent existence of the problem little information is available on the biology and control of this insect. This is especially true for conditions in Florida.

In 1966, the Department of Entomology of the University of Florida initiated a researcin project entitled the "Bionomics and Control of the Two-lined Spittlebug, Prosapia bicincta (Say), in Tronical and Sub-tropical America." Tris project was financed through a research grant from the 
Center for Tropical Agriculture. It was originally planned that research would be conducted in sub-tropical areas of Florida and in a tropical country such as Costa Rica. It was hoped that information gained in subtropical Florida would complement that from the tropics and vice-versa. Research was conducted from September, 1966, to June, 1969, in three locations in Florida. In addition, six weeks were spent in 1967 studying a similar pest species of spittlebug, Prosapia plagiata (Distant), which attacks pasture grasses at high elevations in Costa Rica. Accordingly, this dissertation is divided into two sections. Greater emphasis is placed on $\underline{P}$. bicincta, with only a few notes given on the biology and control of $\underline{\text { P. plagiata. }}$ 
REVIEW OF THE LITERATURE

Because the subject deals with broad categories of only one species, Prosapia bicincta, an exhaustive review of the literature was compiled. With possibly a few exceptions, all references on biology and control were incorporated into this review.

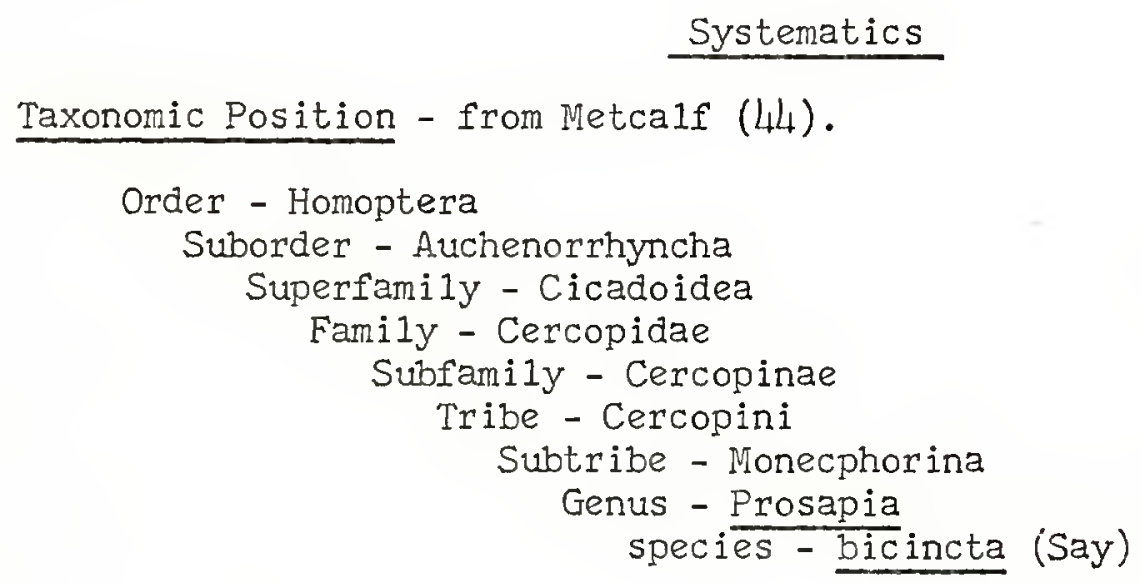

Synonymy

Cercopis bicincta Say, 1830. (51) (Type locality-Indiana)

Monecphora negiecta Wa1ker, 1851. (90)

Monecphora bicincta Signoret, 1853. (52)

Tumaspis is asciatico11 is Stal, 1864. (54)

Tomaspis bicincta Stal, 1864. (54)

Iomispis negiecta Berg, 1879. (4)

Prosapia bicincta Fennah, 1953. (17)

Eescription of the Adult

The adult is $8-10 \mathrm{~mm}$ in length. When viewed from above, the anterior margin of the pronotum is straight and the head is narrower than the pronotum. The dorsal surface is black with the margin and median line of the vertex, eyes, ocelli, and lateral margins of the pronotum red. Generally two lines transvarse the wing covers. These lines and an interhumeral 
line are red to creamy-yellow (22). Many authors have described or pictured the adult or have illustrated morphological structures such as the genitalia or wing venation $(1,12,13,15,17,22,30,45,53,55,16)$. Relationship of the Species

$\underline{p}$. bicincta is the sole representative of the genus north of Mexico. Fennah (17) recognized four species as belonging to the genus. Concurrently, he placed six subspecies under bicincta. These are $\underline{P}$. bicincta bicincta (Say), $\underline{P} \cdot \underline{b} \cdot \underline{i g n i p e c t a ~(F i t c h), ~} \underline{P} \cdot \underline{b} \cdot \underline{\text { angusta }}$ (Walker), $\underline{P} \cdot \underline{b}$. basalis (Walker), $\underline{P} \cdot \underline{b}$. bifascia (Walker), and $\underline{P} \cdot \underline{b}$. fraterna (Uhler). There is some doubt as to the validity of some of these subspecies, especially ignipecta and fraterna.

Races

Fitch (20) described Monecphora ignipecta as like M. bicincta but without any bands or spots dorsally. Most authors have treated it as a variety or color form $(1,15,46,55)$. However, Fennah (17) calls it a geographical subspecies. In general, the dark form is more common in the New England states but certainly is not confined to that area (44). Boring (5) concluded through a cytological study of the chromosomes that the dark form was identical to the banded form.

\section{Range}

Metcalf (44) lists the known geographical distribution of $\underline{P}$. bicincta as the United States: Arkansas, Connecticut, District of Columbia, Florida, Georgia, Indiana, Iowa, Kansas, Louisiana, Massachusetts, Maryland, Maine, Missouri, New Jersey, New York, North Carolina, Ohio, Pennsylvania, Texas, Virginia, West Virginia, Wisconsin; Jamaica, Mexico, Cuba, Central America, Costa Rica, Guatemala, and the West Iniies. The range can be generally described as along the Atlantic slope from Nev York and Massachusetts south, throughout the Gulf States and up the Mississippi valley as far as 
central Iowa (1). Cther states in which $\underline{P}$. bicincta has been recorded are Alabama (70), South Carolina (60), Delaware (67), and Michigan (30).

The two-lined spittlebug is a potential pest of improved pastures throughout Florida. It has been reported as a pest on pastures north to North Carolina (80) and west to Texas (87). The adults have been reported injuring holly trees north to Delaware (66) and west to Kansas (73). Host Plants

The nymphs have been recorded feeding on a wide variety of plants, predominantly grasses. Only plants on which nymphs have been recorded are considered here as the true hosts. Plants on which adults have been recorded feeding are treated separately. Citation of a plant species by several authors probably indicates that it is a favored host. A review of host plants recorded in Florida is presented in the Results.

Host plants on which nymphs have been recorded

Scientific Name

Avena sativa $L$.

Andropogon muricatus

A. scoparius

Cynodon dactylon (L.) Pers.

Digitaria decumbens Stent

Digitaria sp.

Eremochloa ophiuroides (Munro) Hack. Panicum humidianum

P. maximum JacG.

Paspaluni notation Filugge

Pennise un glaucum (L.) R.Br.

P. typhoides (Burm.) Stapf \& Hû̉.

Saccharum officinarum I.

Sorqnum ralapense

S. vilogite Pers.

Stenotaphrun secundatum (Walt.) Kuntze

Zea mays $i$.
Common Name and Reference

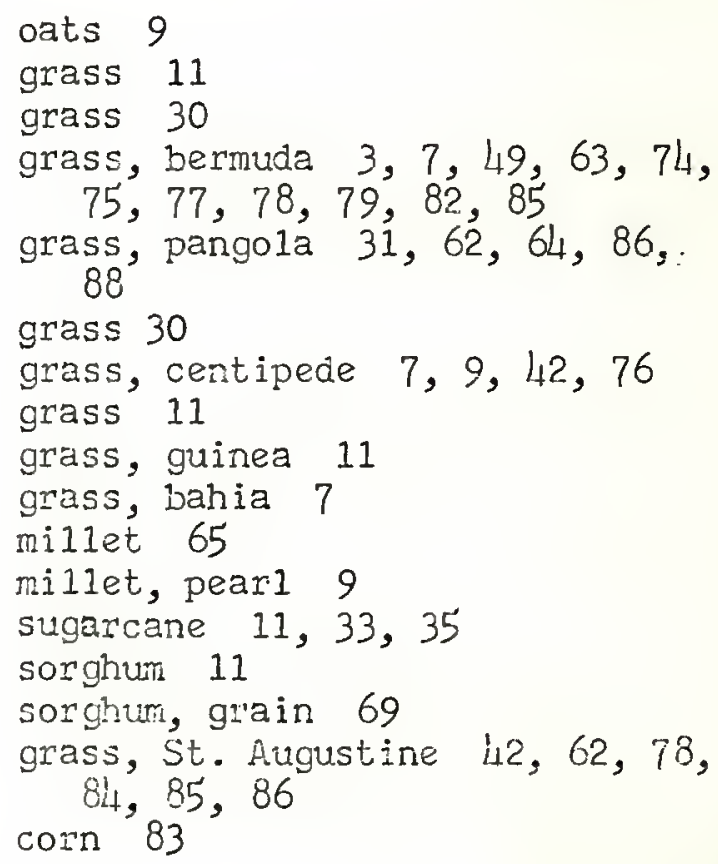


Plants on which feeding adults have been ": orded

Scientific Name

Andropogon sccparius

Cercis canadensis $L$.

Ilex cornuta Burfordi i DeFrance

I. opaca L.

Malpighia glabra L.
Commori Nvat?

grass it?

redbud ine. $20,68,81$

Burford ho:

American $r$ :

Barbados

Pass and Reed (49) 1isted 35 host plants for Sw: Carolina but did not differentiate the plants on which nymph were $r$. bad. Description of the Egg

Beck (3), Byers (7), and Pass and Reed (49) gil scriptions of the egg and development. Although these accounts vary i.1y, each report follows a consistent pattern. Eggs range from $1.0 \%$ $01.09 \mathrm{~mm}$ in length and $0.27 \mathrm{~mm}$ to $0.37 \mathrm{~nm}$ in diameter. When first $1 \mathrm{a}^{\circ}$ elongate ovoid, tapered to a point at the anterior e egg is yellow, and blunity rounded at the posterior end. In 4 to 6 days an "egg burs" $\quad$ rms, suls the chorion, and protrudes until the nymph emerges. $A:$ to to 12 lays, red eye spots appear on either side of the egg near tr. "ion en? and two red areas appear near the posterior end of the eg: : abdom rat region of the embryo. These red areas later coincide wird i reddist spots on each side of the abdomen of the nymph. Under optin: alition nymphs emerge in 12-17 days and in the process of hatch:t a the "gg burster" and the attached cuticle. The eggs are pictured by (7). Description of the Nymphal Stages

Some confusion exists concerning the muber Nympal insters. Cardin (11), Byers (7), and Washbon (91) report rour in. Le Frse anỏ Read (49) report five. Weaver and king (92) found fivt es for the meadow spit.t.ebug and Fewkes (18) noted five for the sught fropinopner. The - Iterature indicates that five instars are the mite cercopics end is 
probably correct for $\underline{P}$. bicincta. Metcalf (43) illustrated the wing venation of the developing nymph and the antenna is illustrated by Moore (46) and Hanna and Moore (30).

\section{Life History}

\section{Egg Stage}

In Cuba, eggs required 12 to 20 days to hatch during the rainy season (11). Beck (3) reported that eggs placed on moist filter paper and held at $80^{\circ} \mathrm{F}$ in the laboratory hatched in 14 to 23 days with an average of 17 days. Eggs held under more varying conditions hatched in 18 to 29 days. Pass and Reed (49) found that in the greenhouse the incubation period averaged 12 days. In an experiment conducted by Byers ( 7 ) at 100\% R.H. and $80^{\circ} \mathrm{F}$, eggs hatched in 17-39 days. Nymphal Stages

No specific figures are available concerning the time required for individual instars. However, Byers (7) indicates that about 7-10 days are needed to complete an instar. Under insectary conditions, nymphs required 43 to 75 days, or an average of 60 days to complete development to the adult stage (3). Pass and Reed (49) reported that in the field, the nymphal period ranged from 34 to 60 days. Nymphs required from 32 to 40 days to complete development in Cuba (11).

Adult Stage

In laboratory cages at $80^{\circ} \mathrm{F}$ and $70 \%$ R.H., males lived an average of 22.7 days and females an average of 23.7 days (7). Beck (3) kept field collected adults alive as long as 30 days in the laboratory. In greenhouse cages, where the temperature ranged from $22^{\circ}$ to $35^{\circ} \mathrm{C}$, field collected adults remained alive for as long as six weeks (50). One male used in experiments by Byers and Taliaferro (8) lived 33 days. 


\section{Life Cycle and Generations}

When soil plugs containing overwintering eggs were brought into the greenhouse, adults emerged in 81-105 days. In a similar experiment the following year, adults emerged in 77-93 days. Light trap collection curves and nymphal sampling curves indicate that it takes about 60 days to complete a generation and there are two generations per year in Georgia (7). Seasonal History

Aduits have been taken early in June and as late as December in 1 ight traps at Tifton, Georgia. Generally there are two periods of abundance, one in June and another in August to early September $(3,7)$. Adults appear from March to November in the Clemson area. Greatest numbers were observed during the last week of July or the first week in August (49). In Cuba, the spitilebug is found in greatest numbers during September, October, and November (11). Adults have been taken in New England from the last week in July until the latter part of September (47).

\section{Habits}

The Adult

Locomotion.--Adults are only moderately active and it is possible to catch them by hand (7). Cardin (11) states that they fly rapidly from $2-5$ meters when disturbed. On two occasions, spittlebugs were observed to fly in excess of 100 feet in a single flight (49).

Feeding.--Cardin (11) reported that the adult feeds in the same way as the nymph, by sucking the juices at the base of the plant. Hume (34) described the adult feeding on holly which caused the leaves to turn yellow and drop. Byers and wel1s (9) denonstrated that both the nymphs and adults probe into the xylem of host grasses.

Effects of environment on activities...-Cardin (1i) states that the insect 
is active at night and can be taken by light trap. Wany authors have reported ${ }_{-}$. bicincta in 1 ight trap collections $(3,7,23,24,49,50)$. In the field, adults are most easily found in the morning when dew is on the grass. Iater in the day they seek shelter deep in the grass (7, 11). Beck (3) states that no attempt has been made to associate activity with weather conditions.

Mating and oviposition.--Caged pairs first mated when the female was 5 to 9 days old. Pairs were observed mating 1 to 4 times during the second week of adult life. Females evidently mate before and after oviposition begins and oviposition begins 1 to 4 days after mating. The average oviposition period was 14 days (7). According to Cardin (11) eggs are laid on the soil, very close to the host grass. Beck (3) found eggs behind leaf sheaths of grasses and inserted between the inner and outer epidermis of the leaf sheath. Other investigators found eggs inserted into the stem occasionally and most frequently deposited in the soil or trash around the base of the plant $(7,49)$.

Number of eggs and fertility.--A single female under laboratory conditions deposited 142 eggs (3). In the greenhouse, 60 females oviposited an average of 39.6 eggs (49). Byers (7) reports 50 caged females laid 0-170 eggs per female with the average being 45.1. Beck (3) collected 529 eggs which were $81.3 \%$ viable.

The Nympha1 Instars

Immediately upon hatching, the nymphs make their way to a suitable feeding site and start feeding $(3,7,11,49)$. The new 1 y hatched nymphs require a high humidity for survival until they begin feeding. Spittle is produced witnin 5 minutes to an hour after feeding begins $(7,49)$. The nymphs do not feed at one site all of their lives (7). Early instar nymphs 
are found on the lower part of the plants near the roots, while the later instars feed higher on the plant (11). The feeding sites of the nymphs ranged from $\frac{1}{2}$ in. below to approximately 2 in. above ground level (49). Molting between instars takes place within the spittlemasses.

The Last Nympha1 Instar

Transformation to the adult takes place within the spittlemass formed at the last feeding site of the mature nymph. Ball (2) and Pass and Reed (49) described the manner in which molting is accomplished; the nymphal skin splits over the top of the head and thorax and the adult crawls out. The teneral adult rests inside of the spittlemass until the wings harden. Overwintering

The two-lined spittlebug overwinters in the egg stage in Georgia (7), South Carolina (49), and Florida (91).

Methods of Distribution

Although data on dispersal are lacking the insect is probably capable of long-range travel by the wind. Glick (29) captured adults at night at 500 feet elevation using an airplane sampling device.

\section{Effect on Host}

In jury Caused

Cardin (11) contended that the nymphal stage was more injurious than the adult. Other investigators also stated that Coastal bermudagrass was injured as a result of feeding of both the nymphs and the adults $(3,49)$. Later experiments revealed that only the feeding of the adult causes injury to the grass through the injection of phytotoxic salivary substances (9). Furthermore, neither the age nor the sex of the adult after the first day is a factor in the ability of the insect to produce phytotoxemia (8). A significant reduction in the quantity of roots and soci reserves is 
caused by sustained spittlebug damage (58). Damage by $\underline{\mathrm{P}}$. bicincta is believed to be important in relation to subsequent weed invasion of improved pastures (28). Infestations of the two-lined spittlebug cause serious nutritive depletions in grass (31). Extensive damage lowers the palatability and may reduce or destroy a stand of pangolagrass (31).

Symptoms develop on Coastal bermudagrass within 1-3 days after adults begin feeding. The first symptoms appear as white stippled areas arranged in broken rows. Later these stippled areas coalesce to form streaks. Continued feeding causes the leaf to turn brown and die. The severity of damage is directly proportional to the length of time the adult feeds (9). Parts Affected

Byers and Wells (9) reported that bermudagrass could be completely top killed and new growth would be initiated from below ground. Taliaferro et al. (58) found that spittlebug damage significantly reduced root production and sod reserves but this reduction was primarily a function of the cessation of photosynthesis and other essential life processes in the top growth. Histological studies indicate that the nymphs and the adults feed in the xylem. The toxin appears to move both up and down the stem in the xylem and excapes through the border parenchyma into the mesophyl1 in the leaves where it causes loss of chlorophyll and, later, death of both parenchyma and mesophyl1 (9).

\section{Contro1}

Natura1 Control

Eromley (6) recorded an asilid, Erax rubibarbis Macquart, preying on Tomaspis bicincta in Massachusetts. Wray and Brimley (94) found specimens of Monecphora bicincta as victins of pitcher plants in North Carolina. These are the only records of parasites or predators of any of the life stages reported in the literature. 
Cultura1 Control

Beck (3) observed that burning Coastal bermudagrass in April gave $100 \%$ control in Georgia. Mowing and raking also reduced the nympha1 population. From these observations, he concluded that the insect may be substantially controlled by good pasture management and efficient use of the grass as forage. Hodges et a1. (31) suggests heavy grazing or making hay or silage of spittlebug infested pangolagrass as a means of controlling or reducing the damage by spittlebugs. Apparently burning injures pangolagrass (31).

Chemica1 Contro1

Genung (25) obtained good control of $\underline{P}$. bicincta with $31 \mathrm{~b}$ AI/acre of toxaphene in 100 gallons of water. McCaleb and Hodges $(40,41)$ got no control with toxaphene, dieldrin, methoxychlor, or parathion at $2 \mathrm{lb}$ AI/acre.

Control of the nymph.--Pass and Reed (49) applied 11 insecticides to Coastal bermudagrass 15 inches high and obtained no significant control of the nymphs. However, they found that Guthion, endosulfan, endrin, and DDT sprays at $0.5,0.5,0.25$, and $1 \mathrm{lb} \mathrm{AI/acre,} \mathrm{respectively,} \mathrm{gave} \mathrm{good}$ control of nymphs in 2 inch high bermudagrass stubble. In another experiment, good nymphal control was obtained in tall grass with granular heptachlor and endosulfan at $0.5 \mathrm{lb}$ AI/acre.

Byers (7) found that granular endosulfan, phorate, and lindane at $1-2,0.5$, and $0.251 \mathrm{~b} \mathrm{AI/acre,} \mathrm{respectively,} \mathrm{significantly} \mathrm{controlled}$ the nymphs. 
Materials used against the nymphs and their effectiveness.

\begin{tabular}{|c|c|c|c|c|}
\hline Treatment & $\begin{array}{c}\text { Lb } \\
\text { AI/acre }\end{array}$ & $\begin{array}{l}\text { Signifi- } \\
\text { cance of } \\
\text { control }\end{array}$ & $\begin{array}{l}\text { Percent } \\
\text { control }\end{array}$ & $\begin{array}{l}\text { Refer- } \\
\text { ence }\end{array}$ \\
\hline Azodrin EC & 0.6 & a & 91 & 91 \\
\hline Carbaryl & 2.0 & $-b$ & 58 & 49 \\
\hline Carbary1 & 1.0 & $t^{C}$ & & $\begin{array}{r}7 \\
01\end{array}$ \\
\hline Carbary1 G & 2.0 & & 13 & \\
\hline Carbophenothion & 1.0 & - & 62 & 49 \\
\hline Carbophenothion & 1.0 & + & & 7 \\
\hline Dasanit $G$ & 1.6 & & 51 & 91 \\
\hline DDT & 1.0 & - & & 49 \\
\hline DDT & 1.0 & + & 71 & 49 \\
\hline Diazinon G & 0.5 & - & & 3 \\
\hline Diazinon G & 0.5 & - & & 49 \\
\hline Diazinon G & 1.4 & & 42 & 91 \\
\hline Diazinon $G$ & 2.2 & & 85 & 91 \\
\hline Dimethoate & 2.0 & + & & 7 \\
\hline Dimethoate EC & 0.5 & & 75 & 91 \\
\hline Di-Syston & 2.0 & + & & 7 \\
\hline Dyfonate G & 1.0 & & 63 & 91 \\
\hline Endosulfan & 0.5 & - & & 3 \\
\hline Endosulfan & 0.5 & - & & 49 \\
\hline Endosulfan & 0.5 & + & 73 & 49 \\
\hline $\begin{array}{l}\text { Endosulfan } \\
\text { Endosulfan }\end{array}$ & $\begin{array}{l}0.5 \\
1.0\end{array}$ & $\begin{array}{l}+ \\
+\end{array}$ & & $\begin{array}{r}49 \\
7,10\end{array}$ \\
\hline Endrin & 0.25 & - & & 49 \\
\hline Endrin & 0.25 & + & 73 & 49 \\
\hline Ethion $G$ & 1.0 & - & & 7 \\
\hline Furadan $G$ & 1.0 & & 48 & 91 \\
\hline Guthion & 0.5 & - & & 49 \\
\hline Guthion & 0.5 & + & 91 & 49 \\
\hline Heptachlor G & 0.5 & + & & 49 \\
\hline Malathion & 1.0 & - & 58 & 49 \\
\hline
\end{tabular}


Materials used against the nymphs and their effectiveness (Continued).

\begin{tabular}{|c|c|c|c|c|}
\hline Treatment & $\begin{array}{c}\text { Ib } \\
\text { AI/acre }\end{array}$ & $\begin{array}{l}\text { Signifi- } \\
\text { cance of } \\
\text { control }\end{array}$ & $\begin{array}{l}\text { Percent } \\
\text { control }\end{array}$ & $\begin{array}{c}\text { Refer- } \\
\text { ence }\end{array}$ \\
\hline Meta-Systox-R G & 0.5 & - & & 49 \\
\hline Methoxychlor & 1.0 & - & 67 & 49 \\
\hline Mevinphos G & 0.25 & - & & 49 \\
\hline Mevinphos G & 0.25 & - & & 49 \\
\hline Naled & 1.0 & - & 58 & 49 \\
\hline $\begin{array}{l}\text { Parathion } \\
\text { Parathion G }\end{array}$ & $\begin{array}{l}0.5 \\
1.0\end{array}$ & - & $\begin{array}{l}60 \\
52\end{array}$ & $\begin{array}{l}49 \\
91\end{array}$ \\
\hline $\begin{array}{l}\text { Phorate G } \\
\text { Phorate G } \\
\text { Phorate G }\end{array}$ & $\begin{array}{l}0.5 \\
2.0 \\
2.0\end{array}$ & - & 100 & $\begin{array}{r}3 \\
7 \\
91\end{array}$ \\
\hline $\begin{array}{l}\text { Stathion G } \\
\text { Stathion G }\end{array}$ & $\begin{array}{l}1.0 \\
1.4\end{array}$ & & $\begin{array}{l}48 \\
56\end{array}$ & $\begin{array}{l}91 \\
91\end{array}$ \\
\hline Zinophos & 0.5 & - & & 3 \\
\hline
\end{tabular}

aBlank space means no information was available.

bMeans that the treatment was not significantly different from the check at the $5 \%$ leve1.

CMeans that the treatment was significantly different from the check at the $5 \%$ level.

Control of the adult.--Pass and Reed (49) found that Guthion, malathion, mevinphos, endosulfan, carbaryl, parathion, naled, and methoxych1or applied as sprays at $0.5,1,0.25,0.5,2,0.5,1$, and $1 \mathrm{~b}$ AI/acre, respectively, controlled adult spittlebugs caged over grass.

Byers (7) found that sprays of endrin, 1indane, and methoxychlor at $0.125,0.25$, and $11 \mathrm{~b} \mathrm{AI/acre,} \mathrm{respectively,} \mathrm{controlled} \mathrm{the} \mathrm{adults.}$

Strayer (57) suggested toxaphene, carbaryl, and Phosdrin at 1.5-2.0, 1.5-20, and $0.51 \mathrm{~b}$ AI/acre for spittlebug control in Florida. 
Materials used against the adults and their effectiveness.

\begin{tabular}{|c|c|c|c|c|}
\hline Treatment & $\begin{array}{c}\text { Ib } \\
\text { AI/acre }\end{array}$ & $\begin{array}{l}\text { Signifi- } \\
\text { cance of } \\
\text { control }\end{array}$ & $\begin{array}{l}\text { Percent } \\
\text { control }\end{array}$ & $\begin{array}{l}\text { Refer- } \\
\text { ence }\end{array}$ \\
\hline Azodrin EC & 0.6 & a & 84 & 91 \\
\hline $\begin{array}{l}\text { Carbaryl spray } \\
\text { Carbaryl G }\end{array}$ & $\begin{array}{l}2.0 \\
3.0\end{array}$ & $+b$ & $\begin{array}{r}100 \\
51\end{array}$ & $\begin{array}{l}49 \\
91\end{array}$ \\
\hline Dasanit $G$ & 1.6 & & 72 & 91 \\
\hline $\begin{array}{l}\text { Dimethoate EC } \\
\text { Dimethoate EC }\end{array}$ & $\begin{array}{l}2.0 \\
0.5\end{array}$ & $-c$ & 84 & $\begin{array}{r}7 \\
91\end{array}$ \\
\hline $\begin{array}{l}\text { Di-Syston } G \\
\text { Di-Syston } G\end{array}$ & $\begin{array}{l}2.0 \\
2.0\end{array}$ & - & 23 & 91 \\
\hline $\begin{array}{l}\text { Diazinon } G \\
\text { Diazinon } G\end{array}$ & $\begin{array}{l}1.5 \\
2.2\end{array}$ & & $\begin{array}{l}51 \\
72\end{array}$ & $\begin{array}{l}91 \\
91\end{array}$ \\
\hline Dyfonate $G$ & 2.0 & & 69 & 91 \\
\hline Endrin spray & 0.125 & + & & 7 \\
\hline $\begin{array}{l}\text { Endosulfan spray } \\
\text { Endosulfan spray } \\
\text { Endosulfan spray } \\
\text { Endosulfan spray } \\
\text { Endosulfan spray }\end{array}$ & $\begin{array}{l}0.5 \\
0.25 \\
0.5 \\
1.0 \\
1.0\end{array}$ & + & $\begin{array}{r}100 \\
85 \\
14 \\
85 \\
0\end{array}$ & $\begin{array}{r}49 \\
7 \\
7 \\
7 \\
7\end{array}$ \\
\hline Fenthion $G$ & 2.0 & . & 46 & 91 \\
\hline Furadan G & 1.0 & & 23 & 91 \\
\hline Guthion spray & 0.5 & + & 100 & 49 \\
\hline $\begin{array}{l}\text { Lindane spray } \\
\text { Lindane } G \\
\text { Lindane } G \\
\text { Lindane } G \\
\text { Lindane } G\end{array}$ & $\begin{array}{l}0.25 \\
0.25 \\
0.5 \\
1.0 \\
2.0\end{array}$ & + & $\begin{array}{l}100 \\
100 \\
100 \\
100\end{array}$ & $\begin{array}{l}7 \\
7 \\
7 \\
7 \\
7\end{array}$ \\
\hline Malathion spray & 1.0 & + & 100 & 49 \\
\hline $\begin{array}{l}\text { Methoxychlor spray } \\
\text { Methoxychlor spray }\end{array}$ & $\begin{array}{l}1.0 \\
1.0\end{array}$ & + & 83 & $\begin{array}{r}49 \\
7\end{array}$ \\
\hline Mevinphos spray & 1.0 & + & 100 & 49 \\
\hline
\end{tabular}


Materials used against the adults and their effectiveness (Continued).

\begin{tabular}{|c|c|c|c|c|}
\hline Treatment & $\begin{array}{l}\text { Lb } \\
\text { AI/acre }\end{array}$ & $\begin{array}{l}\text { Signifi- } \\
\text { cance of } \\
\text { control }\end{array}$ & $\begin{array}{l}\text { Percent } \\
\text { control }\end{array}$ & $\begin{array}{l}\text { Refer- } \\
\text { ence }\end{array}$ \\
\hline Mobam G & 2.0 & & 3 & 91 \\
\hline Mocap G & 2.0 & & 15 & 91 \\
\hline Naled spray & 1.0 & + & 94 & 49 \\
\hline $\begin{array}{l}\text { Parathion spray } \\
\text { Parathion } \mathrm{G}\end{array}$ & $\begin{array}{l}0.5 \\
2.0\end{array}$ & + & $\begin{array}{l}94 \\
10\end{array}$ & $\begin{array}{l}49 \\
91\end{array}$ \\
\hline $\begin{array}{l}\text { Phorate G } \\
\text { Phorate G } \\
\text { Phorate G } \\
\text { Phorate G } \\
\text { Phorate G }\end{array}$ & $\begin{array}{l}0.5 \\
1.0 \\
2.0 \\
2.0 \\
1.0\end{array}$ & + & $\begin{array}{l}99 \\
81\end{array}$ & $\begin{array}{l}91 \\
91\end{array}$ \\
\hline $\begin{array}{l}\text { Stathion G } \\
\text { Stathion G }\end{array}$ & $\begin{array}{l}1.4 \\
1.0\end{array}$ & & $\begin{array}{l}67 \\
31\end{array}$ & $\begin{array}{l}91 \\
91\end{array}$ \\
\hline
\end{tabular}

ablank space means no information was available.

bMeans the treatment was significantly different from the check at the $5 \%$ level.

CMeans the treatment was not significant1y different from the check at the $5 \%$ level. 


\section{MATERIALS AND NETHODS}

\section{$\underline{\text { Rearing }}$}

Eggs were collected for laboratory work following the methods developed by Beck (3) and Byers (7). Females caged on grass in 1 quart ice cream cartons inserted their eggs into moist filter paper (Figure 1). Eggs were removed and placed in $9 \mathrm{~cm}$ petri dishes on filter paper, then kept continually moist under greenhouse conditions until hatching.

Nymphal studies were conducted in the field and greenhouse. Nymphs were reared using the method described by Byers and We11s (9). Attempts to rear the nymphs in the greenhouse indicated that unless the humidity is maintained at a high level the young nymphs will not survive. In determining the nymphal instars, head capsules were measured across the outer margins of the eyes and the mesothoracic wing pads were measured from the posterior edge of the pronotum to the posterior tip of the pads. Virgin female spittlebugs were easily collected in the field in the early morning by removing them from spittlemasses where they had emerged as adults. Acults mated readily and were easily maintained in 1 quart ice cream carton cages or larger screen wire cages.

\section{Light Trapping}

Light traps were omnidirectional in coverage and used 15-w General Electric F15TS Blacklight Bi. fluorescent lamps. They were of the general purpose type described by hollingsworth et ai. (32) and purchased from Ellisco, Inc., Fhiladelphia, Pennsylvania. Except when otherwise stated, 


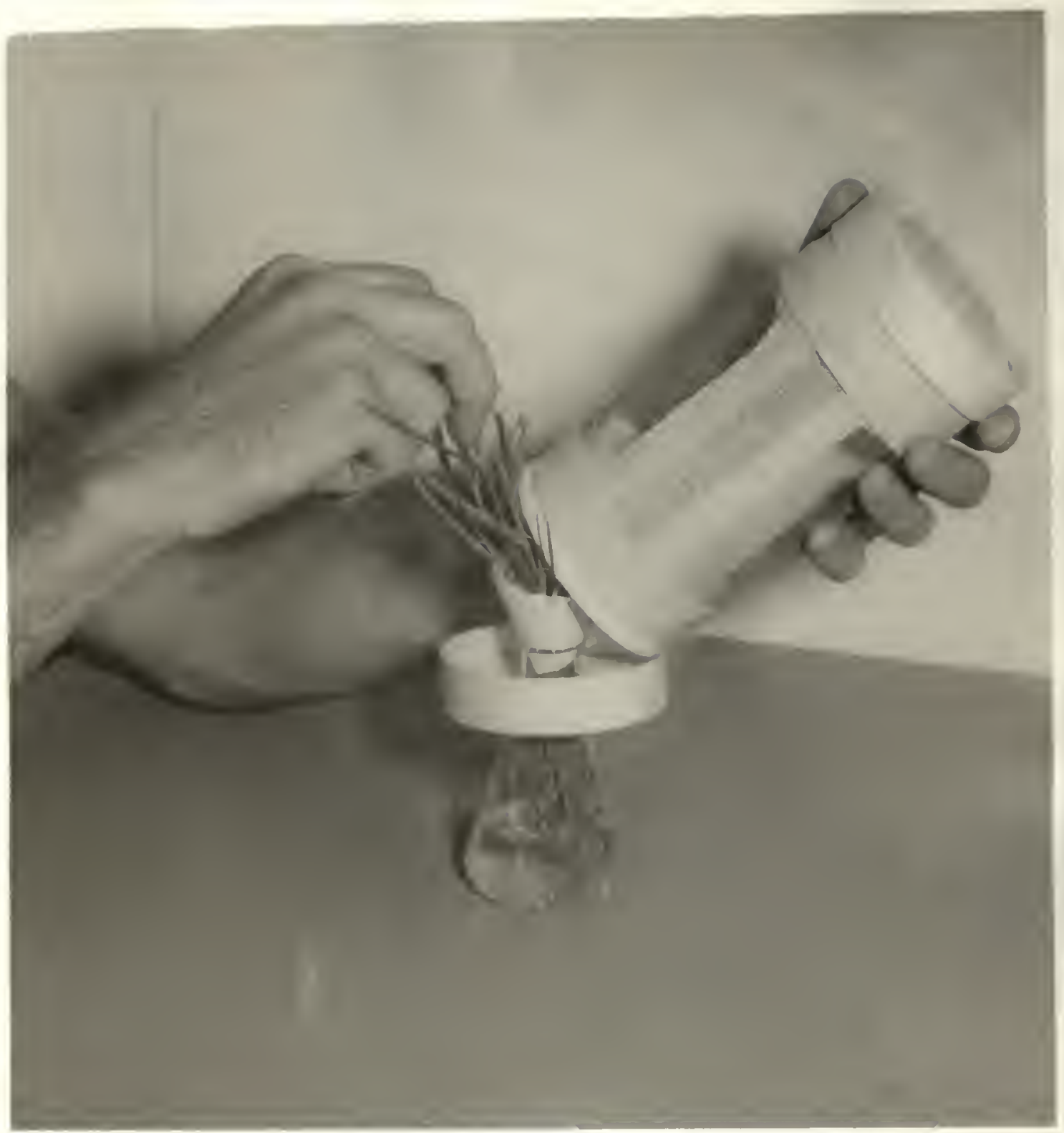

Figure 1.--Female two-lined spittlebugs caged on grass inserted their eggs into moist filter paper wrapped around the grass. 
light traps were placed on stands with the center of the light source 48 in. above the ground. The spittlebugs were trapped and preserved in $70 \%$ isopropy1 alcohol.

Height of Traps

The bidirectional trap consisted of a 15-w, blacklight lamp mounted parallel to the ground in a common bathroom type fluorescent unit (Wiremold Company, Hartford, Connecticut). A 15 in. 1ong, 2 in. deep enamel pan filled with alcohol was placed under the lamp to act as a trap. Placing an omnidirectional trap at heights lower than 36 in. necessitated digging a hole and caused undue awhwardness in handing the collection container which is below ground level. Traps Using Different Colored Lamps

The effectiveness of various colored lamps in attracting spittlebugs was evaluated using 4 standard omnidirectional light traps placed in a straight 1 ine $50 \mathrm{ft}$ apart. Five colors of General Electric Fluorescent Lamps $^{(}$were used in the tests. The colors were rotated so that each had an opportunity at each trap position.

Periods of Flight Activity

To determine the periods of nocturnal adult activity, a light trap which divided the catch into hourly samples was utilized (Figure 2). It was a modification of a design by king et a1. (36). The timer was a 60 Minute Cycle Electric Timer (Supreme Electric Products Co., Rochester, New York). The magnetic solenoid was out of an automatic clothes washer. The turn table was powered by the gravitational pull derived from a pully and weights. The light was centered 48 in. above the ground.

Sticky Board Traps

Wilson and Shade (93) reported on the possibie use of colored sticky 
boards as a survey tool for meadow spittlebug. The Florida siudy was conducted at the Everglades Experiment Station. Boards measuring $12 \mathrm{in.}$ by 12 in. were cut from $\frac{1}{4}$ in. masonite and painted with several coats of paint. Four colors were used: white, green, yellow, and lemon-yellow. These colors were matched to plates from Maerz and Paul (39) and the classification for each shade is given in Table 6. Two boards of the same color were attached to the ends of a stick 1 in. by 1 in. by $2 \mathrm{ft}$ so that the sides of the board at one end faced North and South while those at the other end faced East and West. The boards and crossbar were attached to $2 \mathrm{in.}$ by 2 in. by $8 \mathrm{ft}$ stakes in the field at heights of $3 \mathrm{ft}$ and $6 \mathrm{ft}$. A thin layer of Stickem ${ }^{\circledR}$ (Michel and Pelton Co., Emryville, California) was then applied to the boards to trap the insects. The experiment was designed as a randomized block with the traps $50 \mathrm{ft}$ apart in rows $50 \mathrm{ft}$ apart.

\section{Grass Varieties Trial}

Nineteen grasses were planted on June 7, 1968, in a well established pangolagrass pasture that had received spittlebug damage the previous year (Table 8). Each grass was replicated 4 times in a randomized block design. In each replication, 4 clumps of grass, 6-8 in. in diameter, were planted $1 \mathrm{ft}$ apart in the pangolagrass sod. It was assumed that spittlebugs had an equal opportunity to feed on and damage all of the grasses. Pangolagrass was used as the standard for comparing spittlebug injury. Dr. S. C. Schank provided the Digitaria crosses and the other grasses came from the grass introduction nursery at the Range Cattle Station.

\section{Chemical Control}

Ail experiments vere conducted in randomized complete block designs. Unless stated otherwise, materiais were applied with a Kiekens Whirlwind 


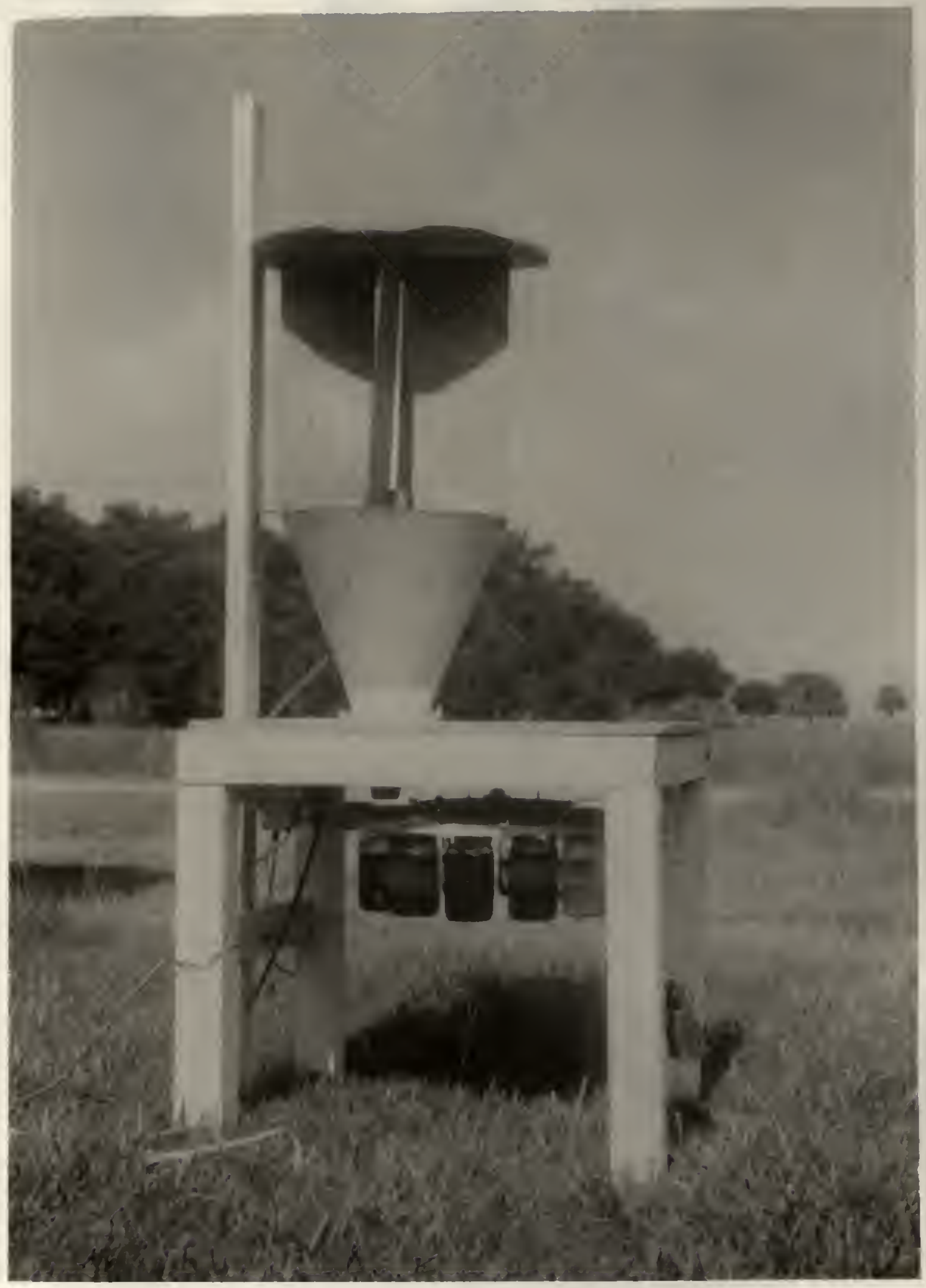

Figure 2.--Light trap, which divided the catch into hourly samples, used to determine periods of two-1ined spittlebug activity. 


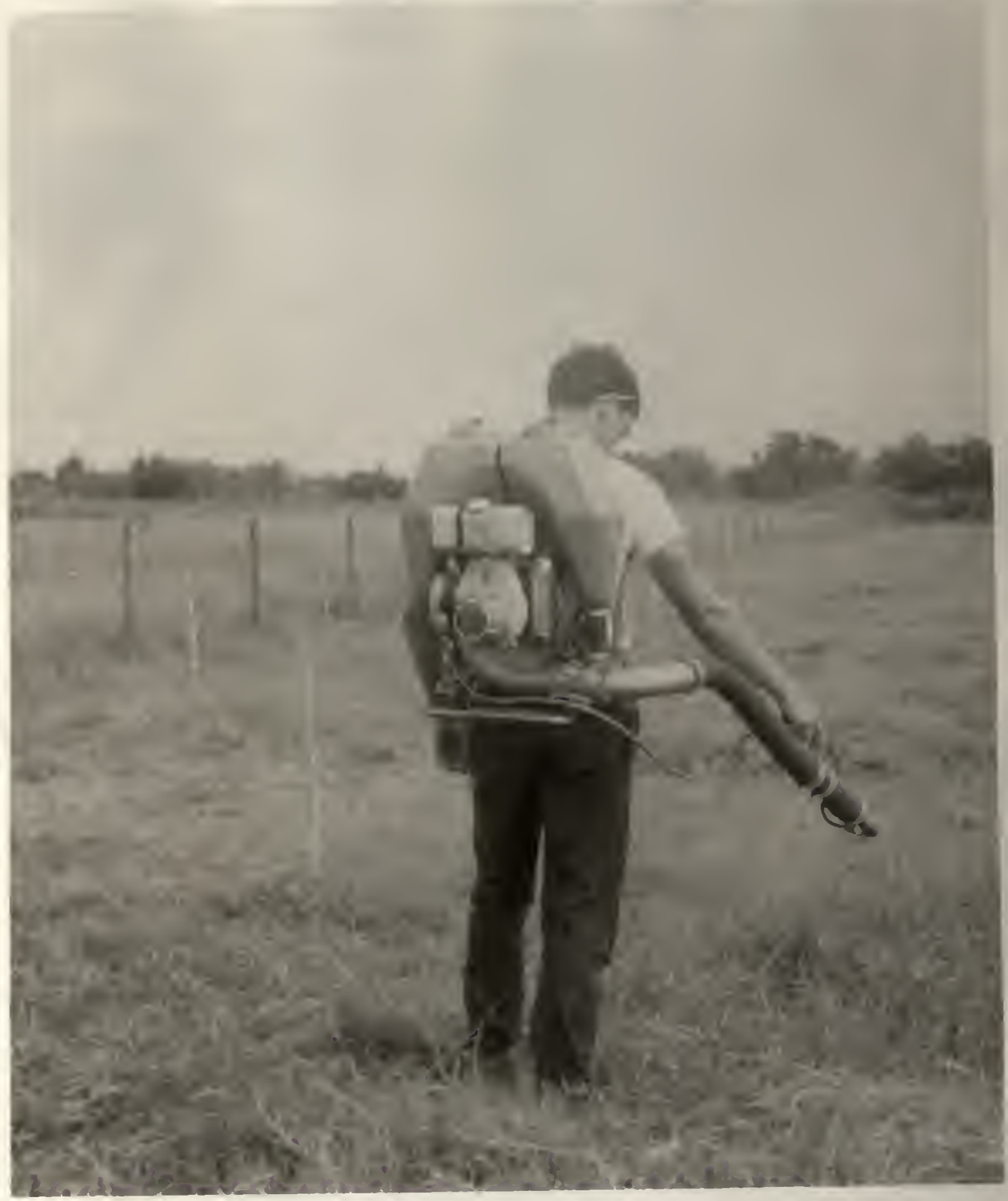

Figure 3.--Gasoline powered knapsack blower used to apply materials in the chemical control experiments. 
Ho1land Mode1 KWH-25 (Vandermolen Export Co., North Caldwe11, New Jersey), a gasoline powered knapsack blower which delivers both wet and dry formulations (Figure 3).

Adults were sampled by making 20 sweeps in each plot. Nymphs were sampled using a $1 \mathrm{ft}^{2}$ metal frame. Al1 the spittlemasses within this perimeter were counted in 5 randomly chosen spots in each plot and expressed as the number of spittlemasses per $f t^{2}$. More than 1 nymph per spittlemass is common, but for convenience, spittlemasses were counted rather than nymphs. Duncan's multiple range test was used to determine significant differences between treatments.

Experiments were conducted at 2 locations in Florida: the Everglades Experiment Station at Be1le Glade on St. Augustinegrass, Stenotaphrum secundatum (Walt.) Kuntze; and the Range Cattle Experiment Station at Ona, on pangolagrass, Digitaria decumbens Stent.

The chemical definitions of insecticides used for which there are no common names are:

Bayer 37289, 0-ethyl 0-2,4,5-trichlorophenyl ethylphosphonothioate Baygon ${ }^{\bigotimes}$ o-isopropoxyphenyl methylcarbamate Dasanit ${ }^{(3)}$, 0,diethyl 0-[p-(nethylsulfiny1)pheny1] phosphorothioate Dursban $^{\circledR}, 0$, 0-diethyl 0-3,5,6-trichloro-2-pyridyl phosphorothioate Dyfonate ${ }^{(B)}$, o-ethy1 S-phenyl ethylphosphonodithioate Supracide ${ }^{\circledast}$, 0-0-dimethyl phosphorodithioate S-ester with 4 -(mercaptomethyl) -2-methoxy- $\Delta^{2}-1,3,4$-thiadiazolin-5-one

Mobam $^{\circledR}$, benzo(b)thien-4-y1 methylcarbamate Mocap ${ }^{\circledR}$, 0-ethy1 S,S-dipropy1 phosphorodithioate UC-30045, methy1 2-isopropy1-4-(methylcarbamoyloxy) carbanilate VCS-506, 0-(2,5-dichloro-4-bromopheny1) 0-methyl phenylthiophosphonoate ER-24li1, formula not available 
1967 Experiments

All of the experiments were conducted in pangolagrass pastures at the Range Cattle Station. In most of the experiments, the treatments and checks were replicated 4 times. The grass was generally $12-15$ in. high at the time of application. Sprays were applied at the rate of 35 gal of water per acre. Specifics for each experiment are as follows:

Experiment 1.--Overwintering eggs apparently do not hatch until moisture is adequate. Newly hatched nymphs tend to warider for a short time in search of feeding sites and should be susceptible to residual insecticides. Chlordane $10 \% \mathrm{G}$, dieldrin $10 \% \mathrm{G}$, and parathion $10 \% \mathrm{G}$, were applied at rates of $31 \mathrm{~b} \mathrm{AI/acre} \mathrm{with} \mathrm{a} \mathrm{tractor-mounted} \mathrm{cyclone} \mathrm{seeder} \mathrm{in}$ plots $18 \mathrm{ft}$ by $250 \mathrm{ft}$. Nymphs were counted 33 days after application and the results are summarized in Table 9.

Experiment 2.--The purpose of this experiment was to determine if mowing or mowing plus insecticides cleared for use on pastures would control spittlebug nymphs. Seven treatments were applied in plots $15 \mathrm{ft}$ by $15 \mathrm{ft}$ (Table 10). The mowed plots were cut 4 in. high with a power lawn mower and the grass removed. Spittlemasses were counted 3 and 7 days after treatment.

Experiment 3.--Four rates of azinphosmethyl EC were applied in plots $25 \mathrm{ft}$ by $25 \mathrm{ft}$ (Table 11). Counts were taken 3, 6, and 16 days after application.

Experiment 4.--The purpose of this experiment was to test the effectiveness of eight experimental insecticides for controlling spittlebugs. The treatments and a check were replicated 3 times in plots $15 \mathrm{ft}$ by $40 \mathrm{ft}$ (Table 12). Adults were sampled 2 and 12 days after application and nymphs at the 3 and 12 day intervals. 


\section{Experiments}

Five experiments were conducted in 1968. Plots measured $25 \mathrm{ft}$ by $50 \mathrm{ft}$ in all but the first experiment. Experiments 1, 2, and 3 were conducted on 10-12 in. high St. Augustinegrass and the last 2 experiments were conducted on 24-36 in. high pangolagrass.

Experiment 1.--This experiment was designed to test the effectiveness of 4 rates of phorate 10\% G against spittlebug nymphs and adults. Treatments and the check were replicated 3 times in plots $25 \mathrm{ft}$ by $25 \mathrm{ft}$ (Table 14). The adult population was sampled 1 and 7 days after application. Nymphs were sampled at intervals of $2,7,14,20,27$, and 57 days following treatment. Precipitation totaled 1.52 in. within $48 \mathrm{hr}$ after application.

Experiment 2.--The $2^{\text {nd }}$ experiment was designed to evaluate the effectiveness of certain insecticides currently used on pastures and vegetables. Seven treatments and a check were replicated 4 times (Table 16). In previous experiments, spray treatments apparently did not reach the nymphs and gave little control. A spreader, Triton $\mathrm{X}-100$, was added at the rate of $3 \mathrm{oz} / 100 \mathrm{gal}$ of water to 2 treatments in an attempt to increase their effectiveness. The 2 treatments containing Triton X-100 were applied in 100 gal of water/acre and all others at 30 gal/acre. No precipitation was recorded for 3 days after the applications. The population was sampled $1,4,8$, and 12 days after application. .

Experiment 3.--In this experiment the effectiveness of a number of experimental materials was determined for controlling two-lined spittlebugs on St. Augustinegrass. Eight treatments and a check were replicated 4 times (Table 17). There was 1.09 in. of precipitation during the first 24 hr after application. The adult population was sampled 3 and 11 days 
after application. Nymphs were sampled at intervals of $3,11,20$, and 34 days after treatment.

Experiments 4 and 5.--These experiments were conducted on ungrazed pangolagrass pastures. The grass was thickly matted near the ground and provided an optimum environment for spittlebugs. The first rain fell 5 days after application ( $1.97 \mathrm{in.})$. The heavy top growth of the grass prohibited sampling of adults by sweep net. Control of the adults was estimated indirectly through visual observations of damage to the grass. Visual rating of the different treatments were made on October 11, 36 days after application (Tables 20 and 22). This was after the spittlebug population had declined but before any frost damage occurred. Nymphs were sampled 6 and 13 days after application.

Seven insecticides and a check were replicated 3 times in the 4 th experiment (Table 19).

In the $5^{\text {th }}$ experiment, 7 insecticides and a check were replicated 4 times (Tab1e 21). 
RESULTS AND DISCUSSION

\section{Biology and Ecology}

\section{$\underline{\text { Eggs }}$}

Description.--Newly deposited eggs are bright yellow and more pointed at the anterior than the posterior end. Fifty eggs averaged $1.02 \mathrm{~mm}$ in 1 ength (range $0.96 \mathrm{~mm}$ to $1.06 \mathrm{~mm}$ ) and $0.35 \mathrm{~mm}$ in width (range $0.32 \mathrm{~mm}$ to $0.37 \mathrm{~mm}$ ). There is no evidence of a micropyle in the chorion of the egg. A faint longitudinal "hatching line" is visible on new eggs from the anterior tip to about the middle of the egg. This area gradually darkens for 5 to 6 days, then a black "hatching 1id" splits the chorion and protrudes until the egg hatches (Figure 4). Eggs 12 to 15 days oid have a red spot on each side of the "hatching 1id" and also on each side of the posterior end. These red areas later coincide with the red eyes and the 2 red areas on the abdomen of the nymph.

Hatching.--Eggs held at $22.2^{\circ}-24.4^{\circ} \mathrm{C}$ on moist filter paper hatched in 16-21 days (mean of 19 days). At hatching the black 1 id breaks away and the nymph emerges head first and ventral side uppermost. Most eggs hatched at night which is probably an adaptation to reduce the hazard of desiccation for the newly emerged nymph. Location.--Caged females show a strong tendency to insert their eggs rather than dropping them at random. Most eggs were inserted into moist filter paper and rarely into the stems or leafsheaths of the grass. In the field, eggs are produced singly but many eggs may be found in one location. They 
Figure 4.--Development of Prosapia bicincta eggs. From left to $r$ ight the eggs are $1,6,12$, and 19 days old (hatched).

(Figure 32 times actual size). 
are deposited in the moist litter and debris at the base of grasses.

Because of the low searching range of the 1 st instar nymph and its susceptibility to desiccation, the female chooses an oviposition site which will provide an optimum high humidity and protection. During months of high rainfall (June-August) and rapid grass growth, eggs are deposited throughout the field. Then, as dry weather approaches in the fall females seek the moist environment provided by bunch grasses (vaseygrass, smutgrass, bristlegrass)and low areas. It is in these locations that most of the overwintering eggs are deposited. Not only do the bunch grasses provide protection by the nature of their growth but they are also among the most unpalatable of the pasture grasses and the least likely to be grazed short during the winter.

Overwintering and the effects of moisture.--During the dry season (October to Apri1) soil moisture in Florida is very low and the spittlebug population overwinters in the egg stage. Eggs were collected from caged females from June to October. When held on moist filter paper under greenhouse conditions, eggs collected from June to August hatched in 16-21 days. One hundred thirty-five eggs collected from September 29 to October 8, 1968, failed to hatch under these same conditions and after 30 days and were considered in diapause. This suggests that eggs oviposited by fall females enter diapause regardless of environmental conditions in the field. What physiological mechanisms induce the fall females to produce diapausing eggs was not ascertained.

These eggs were then held on ary filter paper at $22^{\circ}-24^{\circ} \mathrm{C}$ for 135 days. Upon remoistening, 75\% of the eggs natched in 16-19 days. Therefore, diapause was terminated only by lang exposure to dry conditions. This has been reported for the sugarcane froghopper, Aeneolamia varia 
saccharina Distant (19). The exact number of days under dry conditions needed to break diapause was not determined.

In the field, eggs first hatch in the spring in low areas where moisture is evident. At Ona, during May, 1968, 2-3 weeks before hatching occurred in the field, nymphs were abundant in a strip of St. Augustinegrass kept moist by a septic tank drain. Temperature is undoubtedly important, but diapausing eggs evidently will not hatch unless moisture is adequate. This condition quite possibly results in a synchronous hatching of eggs at the onset of the wet season.

Exposing nondiapausing 1-2 day old eggs to dry conditions delayed hatching. For example, when eggs were dried 8 days, then moistened, they hatched in 24-29 days. When eggs in which the "hatching lid" had split the chorion (6-7 days old) were dried, all of the eggs died. Apparently after the chorion is split the eggs are no longer able to resist dry conditions.

Nymphs

One of the most precarious periods in the life of the two-lined spittlebug is from the time the "hatching lid" splits the chorion of the egg until the newly emerged nymph begins to feed. Eggs and nymphs are very susceptible to desiccation during this period. After the nymph begins to feed, it creates its own micro-climate and is therefore protected from desiccation. Upon hatching, the $1^{\text {st }}$ instar nymph seeks a suitable feeding site. It probes in several spots before the mouth parts are finally inserted and a spittlemass is produced. The manner in which the spittlemass is produced is described in detail by Weaver and King (92). This same articie reviews the theories proposed to explain the source of the material which gives the spittlemass its remarkable stability. Nymphs 
are not confined to one site but move about, expecially following molting. Their movements should render them susceptible to residual insecticides.

In the field, the first nymphs in the spring and the last in the fall are found on dense growing clump grasses. The thick foliage provides protection from drying winds and high temperatures which results in a higher survival rate of newly emerged nymphs. Later instars $\left(3^{\text {rd }}-5^{\text {th }}\right.$ ) seem to be able to withstand lower humidities than the earlier ones.

One to 6 nymphs, sometimes in different instars, have been observed in a single spittlemass. The $3^{\text {rd }}$ instar produces an easily visible spittlemass and is commonly the first one observed in the field. Stems and runners of grass at ground level are favored feeding sites of the nymphs. During wet periods, nymphs crawl up stems to avoid drowning. There, they produce a spittlemass and remain until surface water recedes. Description.--Molting between instars takes place within the spittlemass. Five instars were recognized in this study based on the number of molts observed during rearing and measurements taken of the head capsules and mesothoracic wing pads of both reared and field collected nymphs. Body length was found to be a poor indicator of instars. Measurements from 150 nymphs are summarized in Table 1. First instar nymphs did not have measurable wing pads. Neither Byers (7) or Washbon (91) distinguished between the true $1^{\text {st }}$ and $2^{\text {nd }}$ instars. Their descriptions of the $" 2^{\text {nd }}$, "3rd", and "4h" instars correspond to the true $3^{\text {rd }}, 4^{\text {th }}$ and $5^{\text {th }}$, instars. The 5 instars are shown in Figure 5. Duration of nymphal stages.--Two-1ined spittlebug nymphs were difficult to rear. First instar nymphs were especially susceptible to desiccation so proper humidity was very critical for rearing. Later instars ( $3^{\text {rd }}-5^{\text {th }}$ ) brought in from the field were easier to maintain. Nymphs reared in the 
greenhouse during July averaged $8,8,10,12$, and 12 days for the $1^{\text {st }}, 2^{\text {nd }}$, $3^{\text {rd }}, 4^{\text {th }}$, and $5^{\text {th }}$ instars, respectively. The nymphal stage averaged 50 days.

Host plants.--Adults can probably survive on almost any plant that provides succulent foliage. So only those plants on which the nymph develop are considered the true hosts. Because of the low searching range of the $1^{\text {st }}$ instar nymphs, females probably oviposit on or near plants that will make suitable hosts.

Nymphs have been recorded on 40 plants in Florida (Table 2). These were predominantly grasses on which the adults also commonly feed. Two woody hosts are reported in the literature. Due to the predominance of grasses and grass-like plants, there is some question as to the validity of gebera and Barbados cherry as nymphal hosts. This list was compiled from the literature as well as from personal observations. Citation of a plant species by several authors indicates that it probably is a favored host. Adults

The $5^{\text {th }}$ instar nymph changes in appearance about 24 hours before the final molt as the reddish bands of the adult become visible through the nymphal exoskeleton. Transformation to the adult takes place within the spittlemass formed at the last feeding site of the $5^{\text {th }}$ instar nymph. The nymph often crawls several inches up a stem and feeds long enough to form a spittlemass. Ball (2) first described the manner in which molting is accomplished; i.e., the nymphal skin splits over the top of the head and thorax and the adult crawls out. Most adults emerge in the early morning, rest within the spittlemass until the wings harden, and depart before noon. 


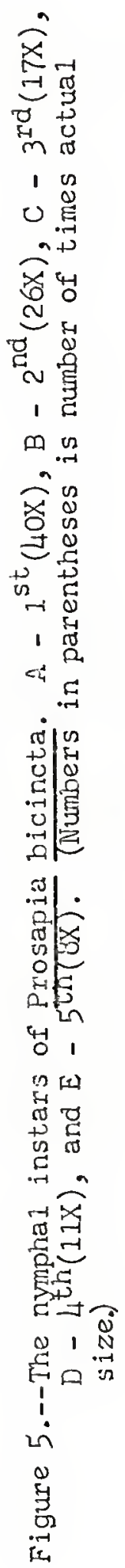




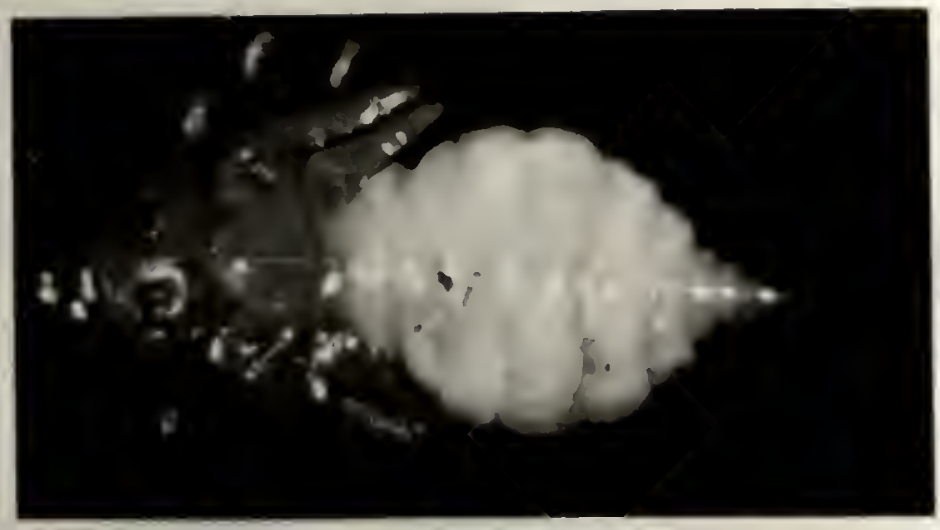

III
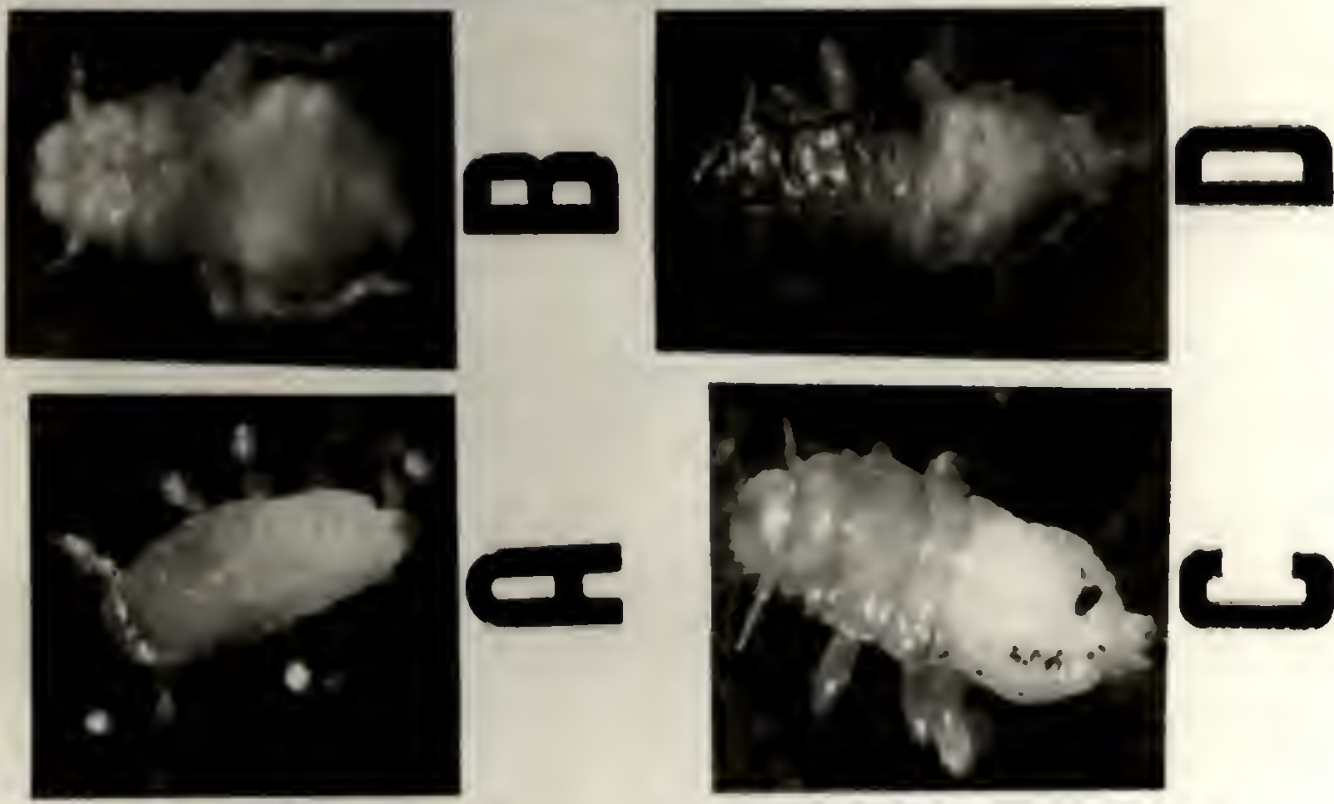

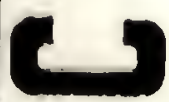


Table 1.--Head capsule and mesothoracic wing pad measurements (in $\mathrm{mm}$ ) of the nymphal instars of Prosapia bicincta in Florida.

\begin{tabular}{ccccc}
\hline Mean & $\begin{array}{c}\text { Mean } \\
\text { head } \\
\text { width }\end{array}$ & Range & $\begin{array}{c}\text { wing pad } \\
\text { length }\end{array}$ & Range \\
\hline I & 0.34 & $0.32-0.37$ & & $0.12-0.15$ \\
II & 0.61 & $0.57-0.69$ & 0.14 & $0.29-0.35$ \\
III & 0.98 & $0.94-1.02$ & 0.31 & $0.79-0.84$ \\
IV & 1.51 & $1.42-1.63$ & 0.82 & $2.40-2.55$ \\
Imago & 2.16 & $2.01-2.25$ & 2.50 & \\
\hline
\end{tabular}


Table 2.--Host list of Prosapia bicincta nymphs in Florida.

Andropogon capillipes Nash

A. nodosus (Willem.) Nash

A. virginicus $L$.

Brachiaria humidicola (Rendle) Schw.

Chloris petraea Swartz

Cynodon dactylon (L.) Pers.

Cyperus distinctus Steud.

C. globulosus Aubl.

Digitaria decumbens Stent

D. gazens is Rendle

D. pentzii Stent

D. sanguinalis (L.) Scop.

D. setivalva Stent

D. Swazilandensis Stent

D. valida Stent

Eleusine indica (I.) Gaertin.

Eragrostis curvula (Schrad.) Nees

Eremochloa ophiuroides (Munro) Hack.

Eriochloa polystachya H.B.K.

Gerbera jamesoni Hook

Hemarthria altissima Stapf \& Hubb.

Malpighia glabra L. bluestem, chalky*

bluestem 27

bluestem, broomsedge*

grass*

chloris, stiffleaf*

grass, bermuda*, 42,91

sedge*

sedge*

grass, pangola*, 62,91

grass*

grass\%, 27

grass, hairy crab*

grass 27

grass 27

grass $*, 27$

grass, goose*

grass 27

grass, centipede 42

grass, carib 91

gerbera 61

grass*

cherry, Barbados 59 
Table 2 (Continued)

Scientific name

Common name and reference

Panicum antidotale Rentz.

grass 27

P. coloratum L.

grass 27

Panicum hemitomon Schult.

maidencane*

P. maximum Jacq.

grass, guinea*, 91

P. purpurascens Raddi

grass, para*, 91

P. repens L.

grass, torpedo*

P. virgatum $L$.

grass, switch*

Paspalum notatum Flugge

grass, bahia*

P. plicatuium Michx.

grass*

P. urvillei Steud.

grass, vasey $*, 87$

Pennisetum ciliare (t.) Link

grass 27

Rhynchelytrum roseum (ITees) Stapf \& Hubb.

grass, natal*

Saccharum officinarum $L$.

sugarcane*

Setaria geniculata (Lam.) Beauv.

bristlegrass*

Sorghum vulgare Pers.

sorghum

Sporobolus

poiretii (Roem. \& Schult.) Hitchc.

grass, smut*

Stenotaphrum

secundatum (Walt.) Kuntze

grass

St. Augustine*, 62

Zea mays $\mathrm{L}$.

corn 91

*Persona1 observation 
Description.--The teneral adults are white except for the red banas on the wings and pronotum. They attain the mature coloration within hours.

Doering (15) differentiated P. (=Tomaspis) bicincta from other related forms according to the following family, generic, and specific characters. The antennae are inserted on the genae between the eyes. There are only 2 stout spines and crown of spines around the apex of the hind tibia. The anterior margin of the pronotum is straight and the head is narrower than the pronotum. The apex of the tegmina is distinctly reticulated. Dorsally the adult is dark brown to black with a narrow orange or red transverse band across the humeral angles of the pronotum and 2 slightly wider bands across the tegmina. Fennah (17) illustrated the genitalia of the male. A dorsal view of the adult is pictured in Figure 6.

Fennah (17) calls the dark form a geographical subspecies occurring in the New England area. In 2 years of 1 ight trapping throughout Florida it was not uncomon to collect adults with one line missing or devoid of lines (Figure 6). This suggests that the dark form is nothing more than a color phase and not a geographical subspecies. Feeding and mating habits.--Adults are more active at night and on cloudy days. During sunny days their habitat is similar to that of the nymphs; i.e., under the canopy of grass next to the soil surface. Adults readily mate in cages. In the field, mating usually was observed in the grass near the ground. Mating was observed at all times during the day and throughout the growing season. Some females of mating pairs captured in the field contained developed eggs, others did not. This indicates that females mate both before and after oviposition begins. Caged females were observed nating more than once.

Caged virgin fenales, 2-6 days old, produced a perfume-1ike odor that 
was very detectable, especially during mornings. On one occasion 2 field collected males were placed with 2 five day old virgin females. Mating took place immediately. However, the exact nature and function of the odor was not ascertained.

Fecundity and longevity.--Eggs were collected from caged females from June to October. Caged females began ovipositing when 7 days old and the average oviposition period was 14 days. Females laid from $0-142$ eggs with the average being 50.3. Of 349 eggs collected from caged females in July, $94 \%$ were viable. Caged females in the greenhouse lived an average of 21 days. Predators and Parasites

No parasites or predators of the eggs or nymphs were found in this study or have been recorded in the literature for $\underline{P}$. bicincta.

W. G. Genung (umpublished data) found remains of the two-lined spittlebug in the stomachs of 8 southern meadow larks, Sturnelia magna argulata (Bangs), at Belle Glade. Presumably many other birds capture spittlebugs. However, Washbon (91) was unable to find their remains in 8 cattle egrets, Bubulcus ibis ibis (L.), killed in September at Belle Glade. Genung also has observed the adults in the webs of the garden spider, Argiope aurantia Lucas, and the golden silk spider, Nephila clavipes (L.). Finally he recorded the reduviid, Zelus bilobus (Say), as a predator.

Many spittlebugs were collected in light traps throughout the season with mites attached to them. Individual adults had up to 6 mites attached mainly to the legs and wing covers. Most of the mites were Leptus sp. (Tromoidiformes: Erythraeidae). One specimen of Clavidromus transvaalensis (Nesbitt) (Mesostigmata: Phytoseiidae) was collected. The mites were idenfied by H. A. Denmark of the Florida State Department of Agriculture, 


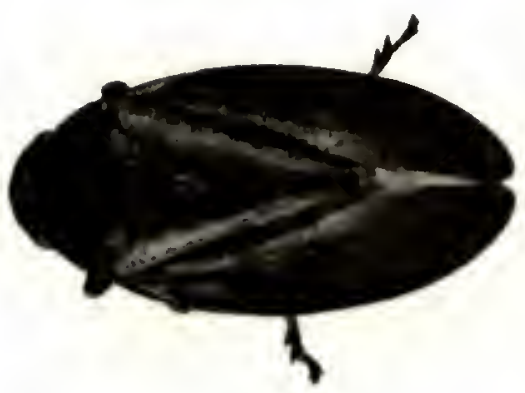

达步

可皆

है

$\rightarrow 0$

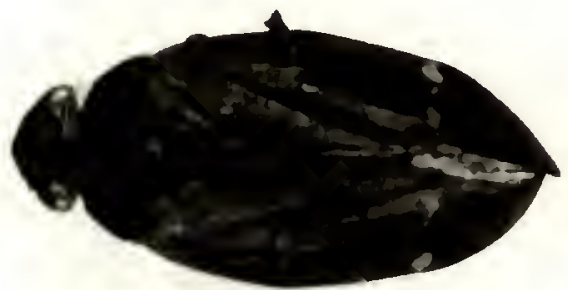

+ :

용ㅇㅇ

i 岌

$+1$

ㄱ.

ठำ

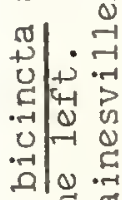
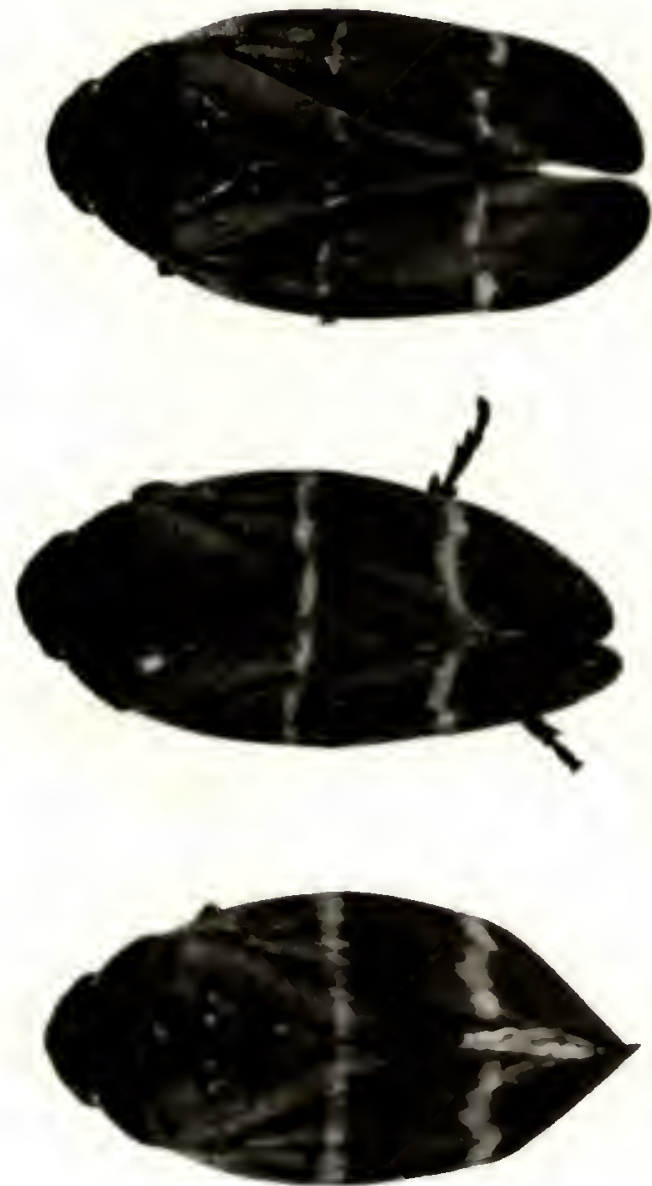

我要

敋结

: 5

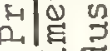

넝 足

-

का थै

⿷匚

牙告

要的

苋웅

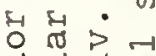

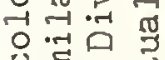

U

क जै

†ण 4

兵害出

骂. +

L

$\rightarrow-10$

政击

$\because$ क

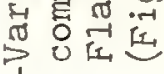

○

है 
Division of Plant Industry, Gainesville.

W. G. Genung (personal communication) has observed a parasitic fungus attacking adult spittlebugs and greatly reducing the population at Belle Glade. Several specimens of adult spittlebugs killed by the fungus were collected at Belle Glade on October 2, 1967. Dr. L. R. Batra of the USDA. Crops Production Research Branch, ARS, Beltsville, Maryland, identified the fungus as Entomophthora grylli Fresenius. The infected insects climb as high as they can on grass stems and weeds and attach with their heads pointing upward. After death, which occurs while they are in these elevated positions, they "mummify" and their bodies remain hanging for several days.

The first parasitized adult was found on June 26 in 1968 at Belle Glade. Later the fungus appeared at the Range Cattle Experiment Station with adults being killed in apparently epidemic numbers. Hundreds of parasitized adults were seen in the field on September 19 attached to many grasses and weeas (vaseygrass, bahiagrass, smutgrass, bermudagrass, pangolagrass, sedges, and dog fennal). Collections made by sweep net, which picked up both dead and live adults, indicated that approximately $45 \%$ of the population was controlled at that time by the fungus.

A review of the literature indicated that investigators had been unable to culture $\mathrm{E}$. gryl1i, so artificial innoculation of healthy spittlebugs was not attempted. However, cultures of 2 species of the genus, Entomophthora coronata and $\underline{E}$. apiculata, were secured from the USDA Insects Affecting Man and Animals Laboratory, Gainesville. These fungi were maintained on Sabouraud Dextrose Agar.

The usual route of Entomophthora infection is by the penetration of the integument, especially the thinner intersegmental areas of the body 
wa11 and the appendages (56). On 2 dates, 10 adult spittlebugs were inoculated with each fungus by allowing them to walk on the cultural plate and then caged on St. Augustinegrass. Only 1 kill was recorded. This was by $\underline{E}$. apiculata and occurred 4 days after inoculation.

Outbreaks of the fungus occur most comonly in August and September in Florida. Warm humid or wet weather seems to be necessary to enable the infection to develop. Steinhaus (56) recognized the destructiveness of E. gry11i in natural outbreaks, but states that it is too dependent upon optimum conditions of temperature and moisture to be a practical means of artificial control.

Life Cycle

The duration of the life cycle undoubtediy is influenced by environmental factors, especially temperature. Eggs probably develop slowly in the spring due to cool nights. However, at $22.2^{\circ}-24.4^{\circ} \mathrm{C}$ about 19 days are needed for the eggs to hatch. Under greenhouse conditions the nymphal period lasts about 50 days. Females begin ovipositing when 7 days old, giving a total of 76 days for the life cycle from egg to egg.

Depending upon temperature and precipitation most of the overwintering eggs hatch from late March to late April. The $1^{\text {st }}$ generation adults are then abuncant in June. The adult population peaks again in early August to early September and this generation deposits overwintering eggs.

The adult population of the last generation is greatly reduced by late September probably due to the fungus disease and the decrease in succulent grasses causcd by the approaching dry season. Although the two-lined spittiebug overwinters in the egg stage, an occasional adult has been taken as late as November $25^{\prime}$ in Gainesville. W. G. Genung (personal communication) has collected an occasional adult by light trap at Belle 
Glade during January and February. The last adults observed in the fall are usually females.

Although there seems to be a somewhat synchronous hatching of over-. wintering eggs in the spring, there is something in the physiology of the eggs and nymphs that inhibits the developrient of members of a given generation. As a result, the life cycles of individuals are not equal and $2^{\text {nd }}$ generation nymphs are soon confused with nymphs from overwintering eggs. This behavior probably aids in maintaining the population by minimizing the probability of a catastrophic event destroying the entire population.

\section{Light Trapping}

The fact that the two-lined spittlebug is attracted to 1 ight has been known for many years. Cardin (11) suggested using light traps to control the adults in 1917. Beck (3) and Byers (7) used 1ight trap catches as indicators of population trends. Both reported that there were 2 peaks of abundance during the year at Tifton, Georgia, one occurring in June and the other in late August to early September. Light traps were used in this study to determine the population abundance and flight activities of $\underline{P}$. bicincta in Florida.

Seasonal distribution.--The seasonal occurrences of adults in light traps at Gainesville for the years 1966-68 are shown in Figure 7. There were 2 pears in the population each year, one in June and another in late August to early September. Although the 2 peaks probably represent 2 generations pen year, about 85 days occurred between the peaks in 1966, 60 days in 1967, and about 82 days in 1968. In 1966 the $1^{\text {st }}$ adult was captured by light trap on Apri1 18 and the last on Octojer 22; in 1967 the $1^{\text {st }}$ was collected May 6 and the last on Octoler 23; and in 1968 the $1^{\text {st }}$ was col- 

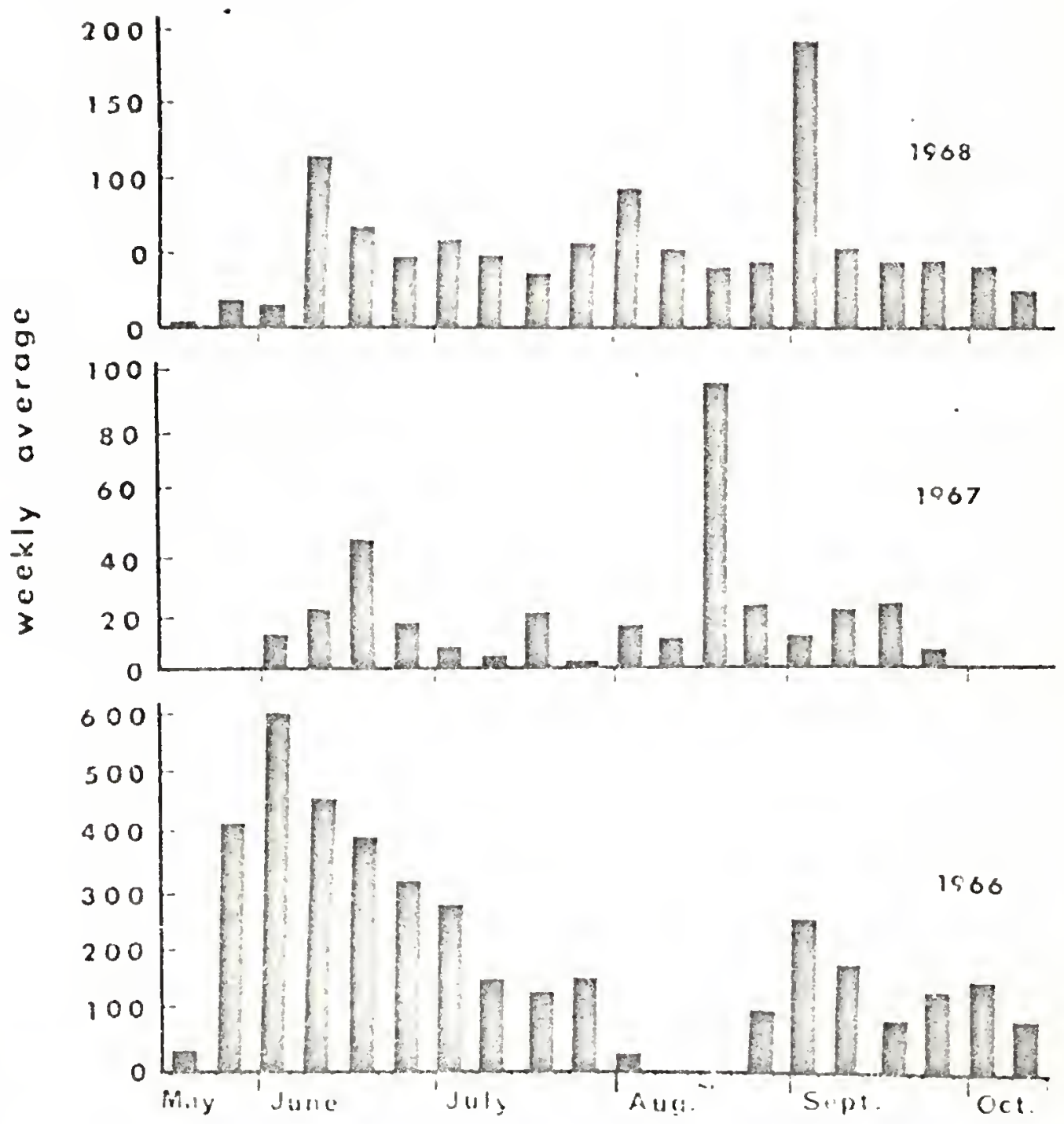

Figure 7.--Week1y occurrence of Prosapia bicincta in light trap catches for three years at fainesvilie, Florida. 
lected May 12 and the last on December 2.

Figure 8 graphically shows the average weekly occurrence of Prosapia bicincta in blacklight traps at the Range Cattle Station in 1967. Data were incomplete with 2 weeks missing in July and none taken after the $3^{\text {rd }}$ week in June. An unusually dry spring apparently delayed adult emergence. Consequently, the normal June peak was not observed.

Male spittlebugs make up a much higher percentage in light trap catches than females. In those data represented in Figure 7, $99 \%$ were males in 1966, 77\% were males in 1967, and 77\% were males in 1968. Figure 9 typifies the seasonal abundance broken down into sex. The number of females captured remains quite low throughout the season but peaks in the female population appear to be identical with that of the males. Field observations show the females to be much more secretive and less active than the males which probably accounts for the low numbers in light traps. Effectiveness of traps at various heights.--Table 3 summarizes data on the effectiveness of light traps equipped with Blacklight BL lamps at different heights for collecting Prosapia bicincta. Omnidirectional traps appear to be more efficient than the bidirectional type. Traps placed with the lamp centered 24 in. above the ground caught more spittlebugs than those at $48 \mathrm{in.}$ and $48 \mathrm{in.} \mathrm{high} \mathrm{traps} \mathrm{did} \mathrm{better} \mathrm{than} \mathrm{those} 120 \mathrm{in.} \mathrm{high.} \mathrm{Re-}$ gardless of the type of trap used, the lower traps appear to capture a slightly higher percentage of females than do the higher traps. Effectiveness of 1 ight traps using different colored lamps.--Studies were conducted at Belle Glade to determine the effectiveness of different colored lamps in attracting spittlebugs to light traps. These data are summarized in Table 4. The Blacklight BL lamps attracted the most spittlebrigs followed by Blacklight BLB lamps. 


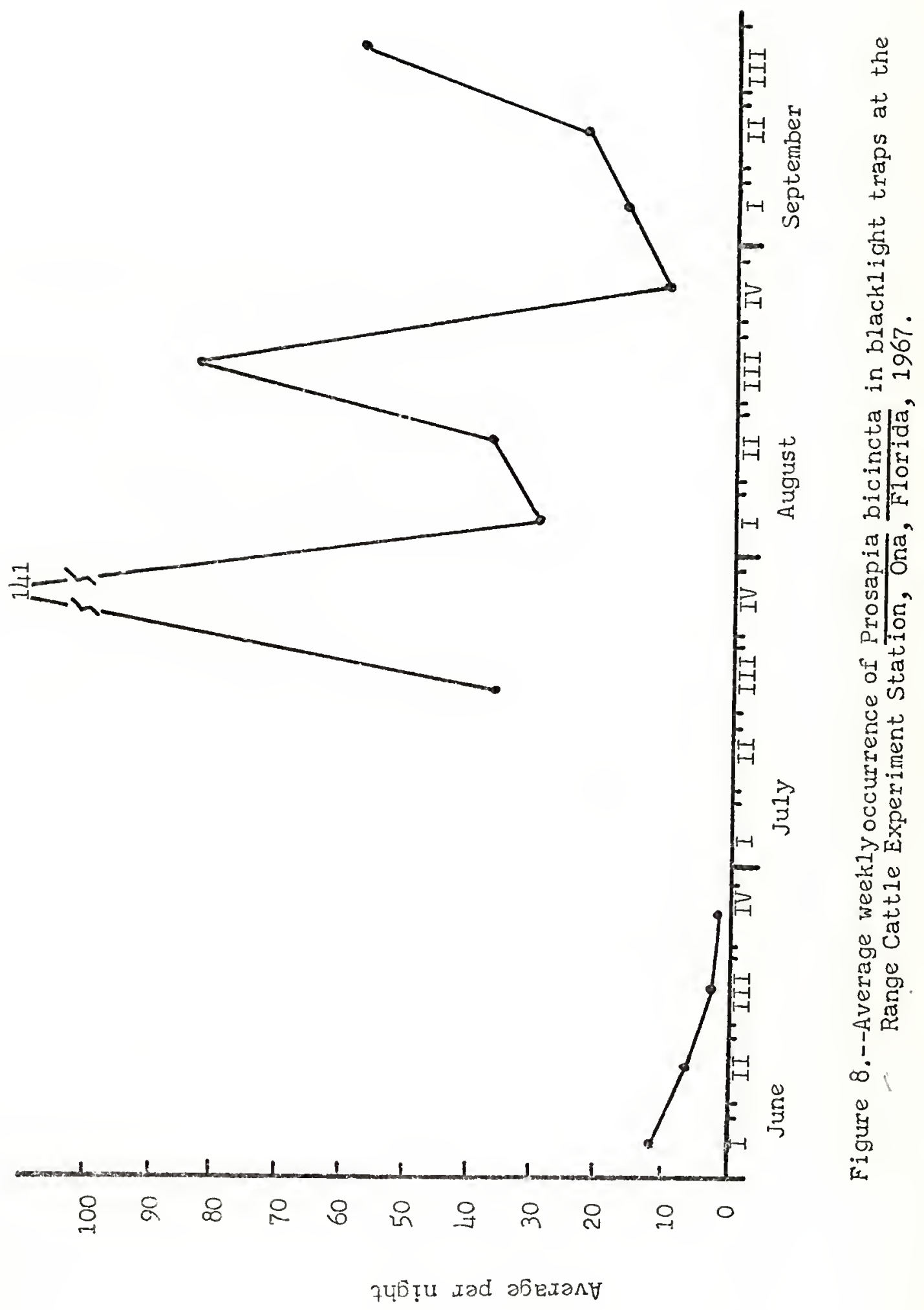




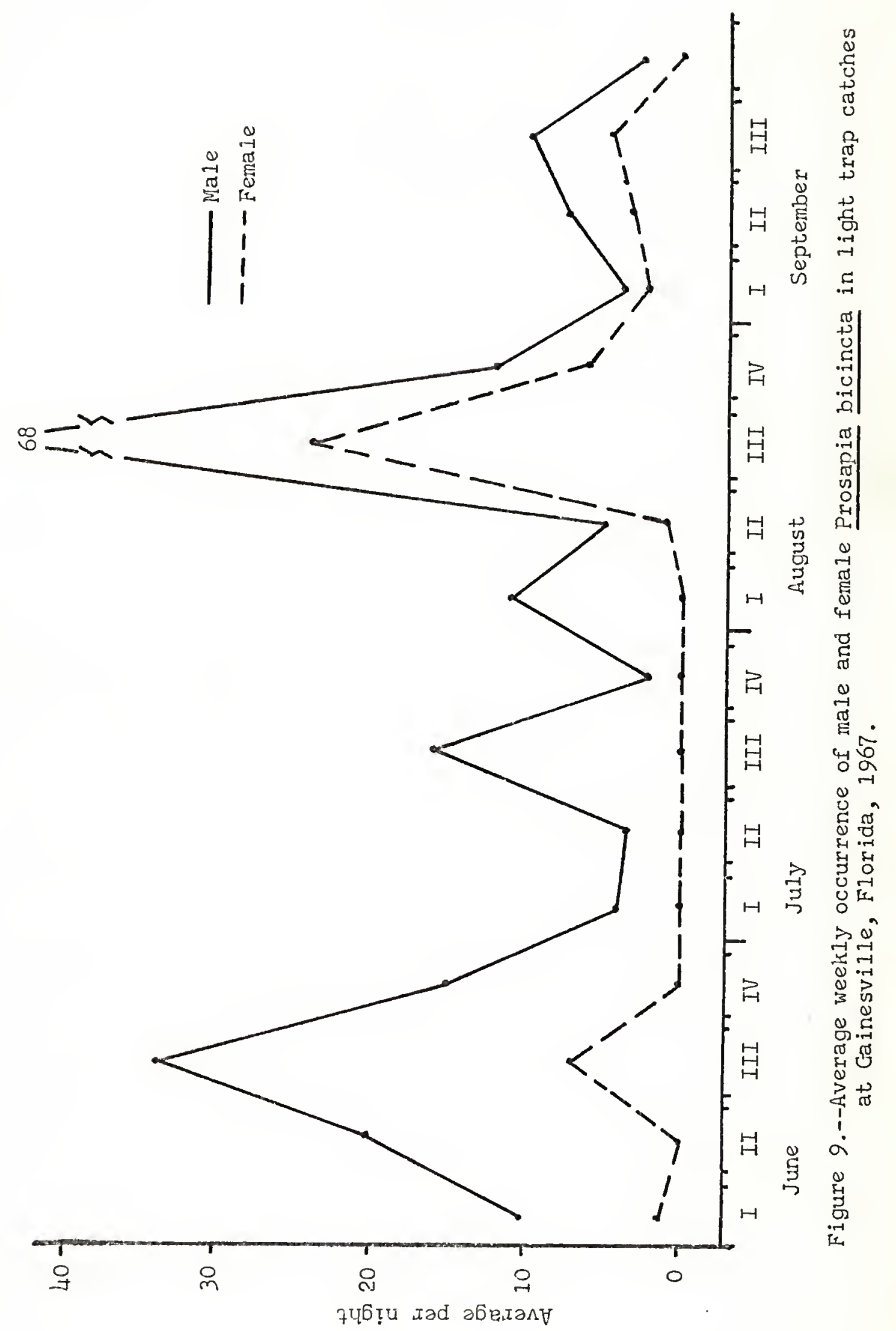


Table 3.--Effectiveness of blacklight traps placed with their lamps centered at various heights above the ground for attracting Prosapia bicincta.

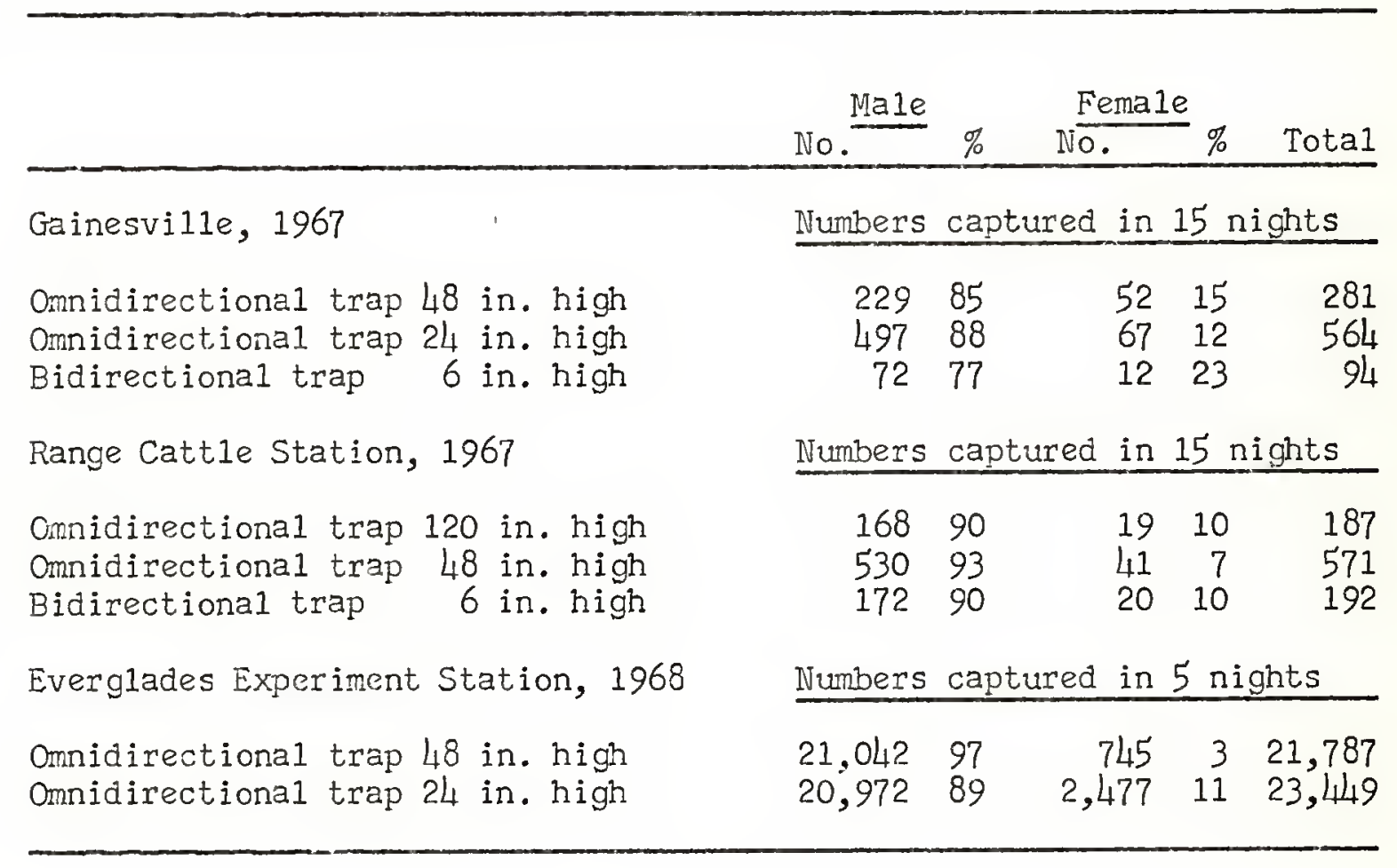


Table 4.--Effectiveness of colored General Electric F15T8 fluorescent lamps in attracting Prosapia bicincta to light traps. Everolades Experiment Station, Belle Glade, Florida, 1968.

\begin{tabular}{|c|c|c|c|c|c|c|}
\hline \multirow[b]{2}{*}{$\begin{array}{l}\text { Lamps } \\
\text { compared }\end{array}$} & \multirow[b]{2}{*}{$6 / 11$} & \multicolumn{4}{|c|}{ Date and adults captured per night } & \multirow[b]{2}{*}{ Tota1 } \\
\hline & & $6 / 12$ & $6 / 13$ & $6 / 17$ & & \\
\hline Blacklight BI & 1080 & 3140 & 455 & 2423 & $=$ & 7098 \\
\hline Cool White & 247 & 319 & 132 & 247 & $=$ & 972 \\
\hline Gold & 33 & 43 & 7 & 36 & $=$ & 119 \\
\hline \multirow[t]{2}{*}{ Red } & 2 & 6 & 2 & 0 & $=$ & 10 \\
\hline & $6 / 18$ & $6 / 19$ & $6 / 20$ & $6 / 26$ & & \\
\hline Blacklight BL & 4893 & 4700 & 8568 & 1089 & $=$ & 24042 \\
\hline Black1ight BLB & 2178 & 2584 & 6479 & 532 & $=$ & 15543 \\
\hline Cool White & 1967 & 1577 & 2960 & 210 & $=$ & 7493 \\
\hline
\end{tabular}




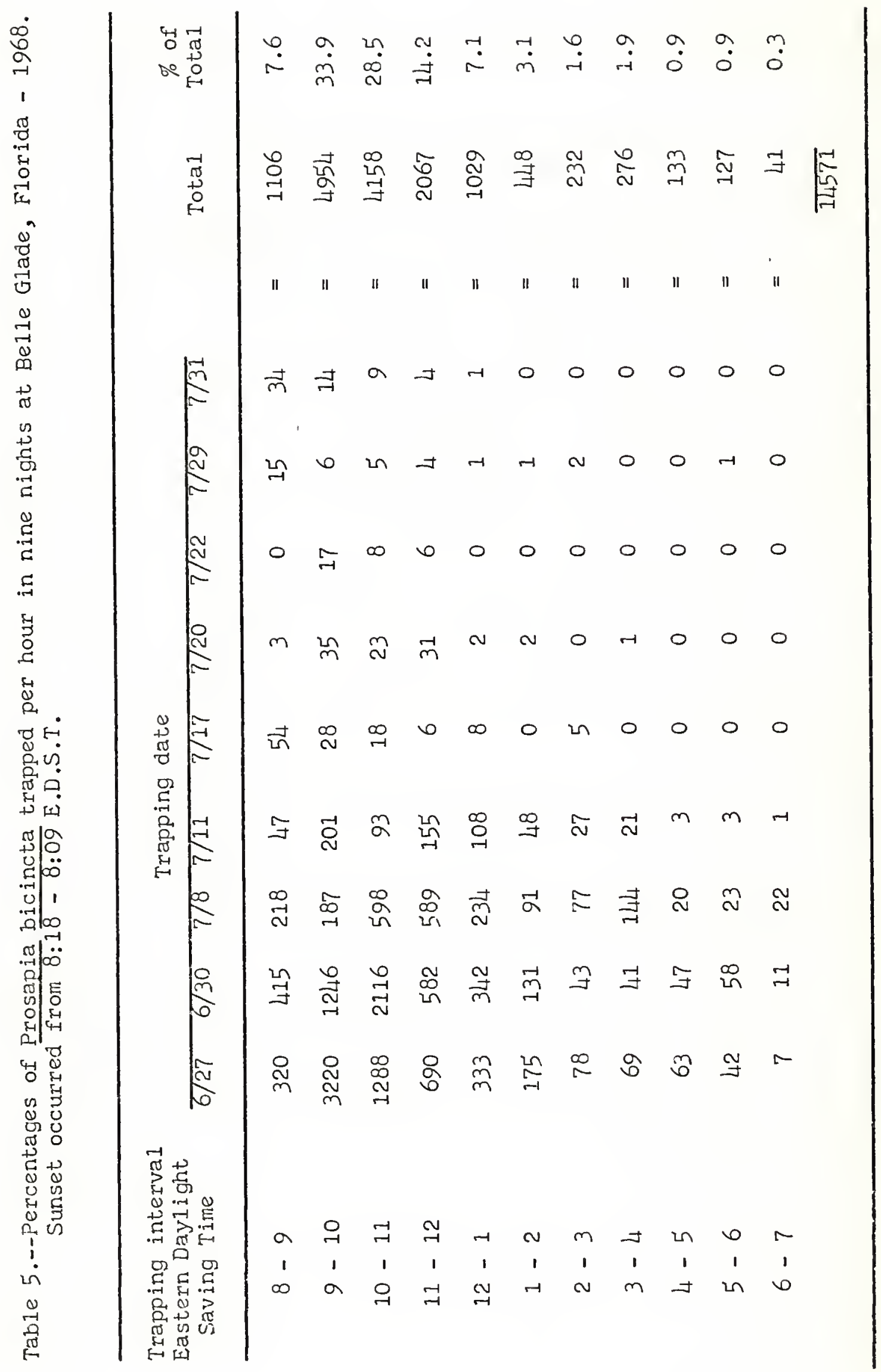




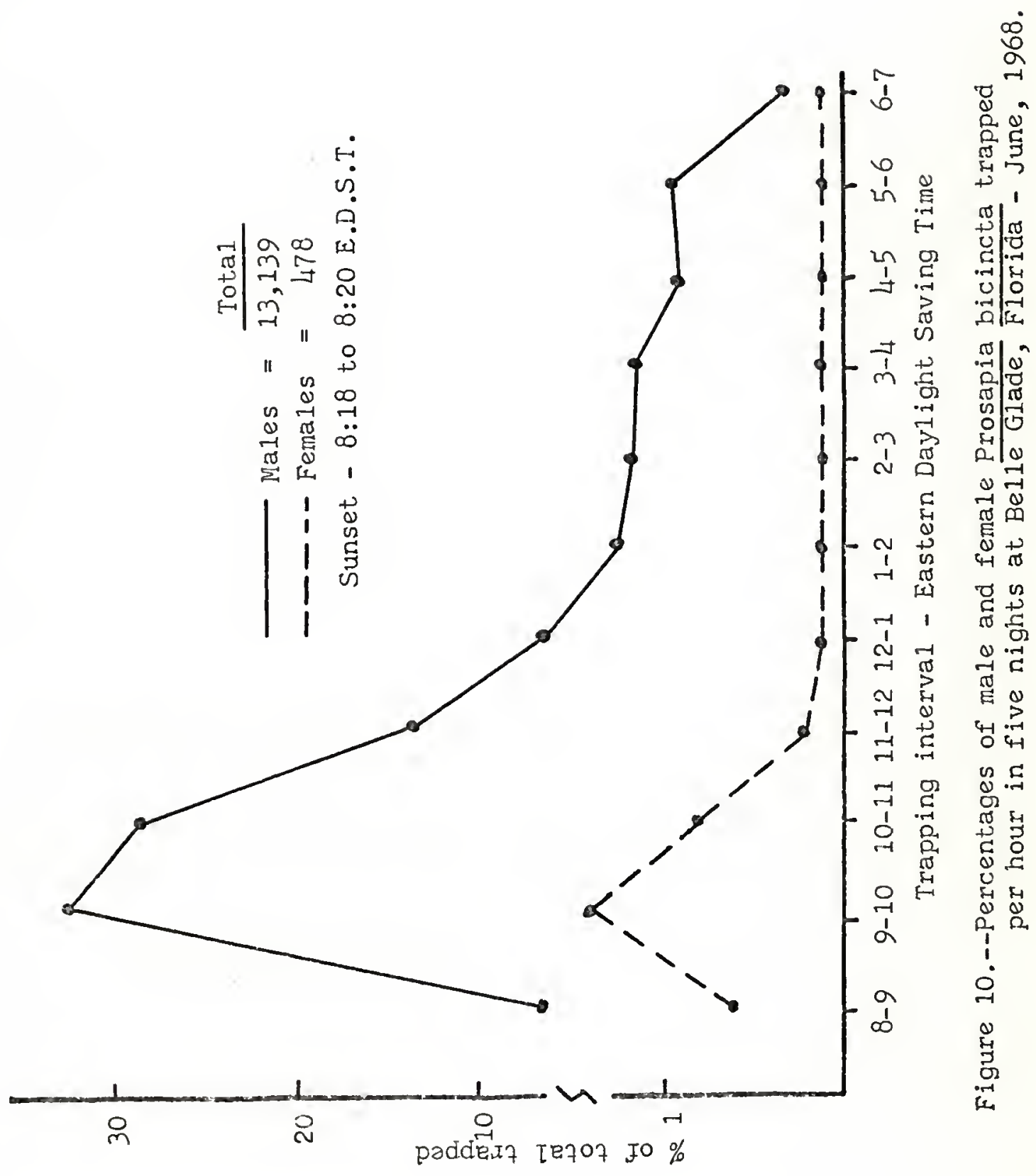


$-54-$
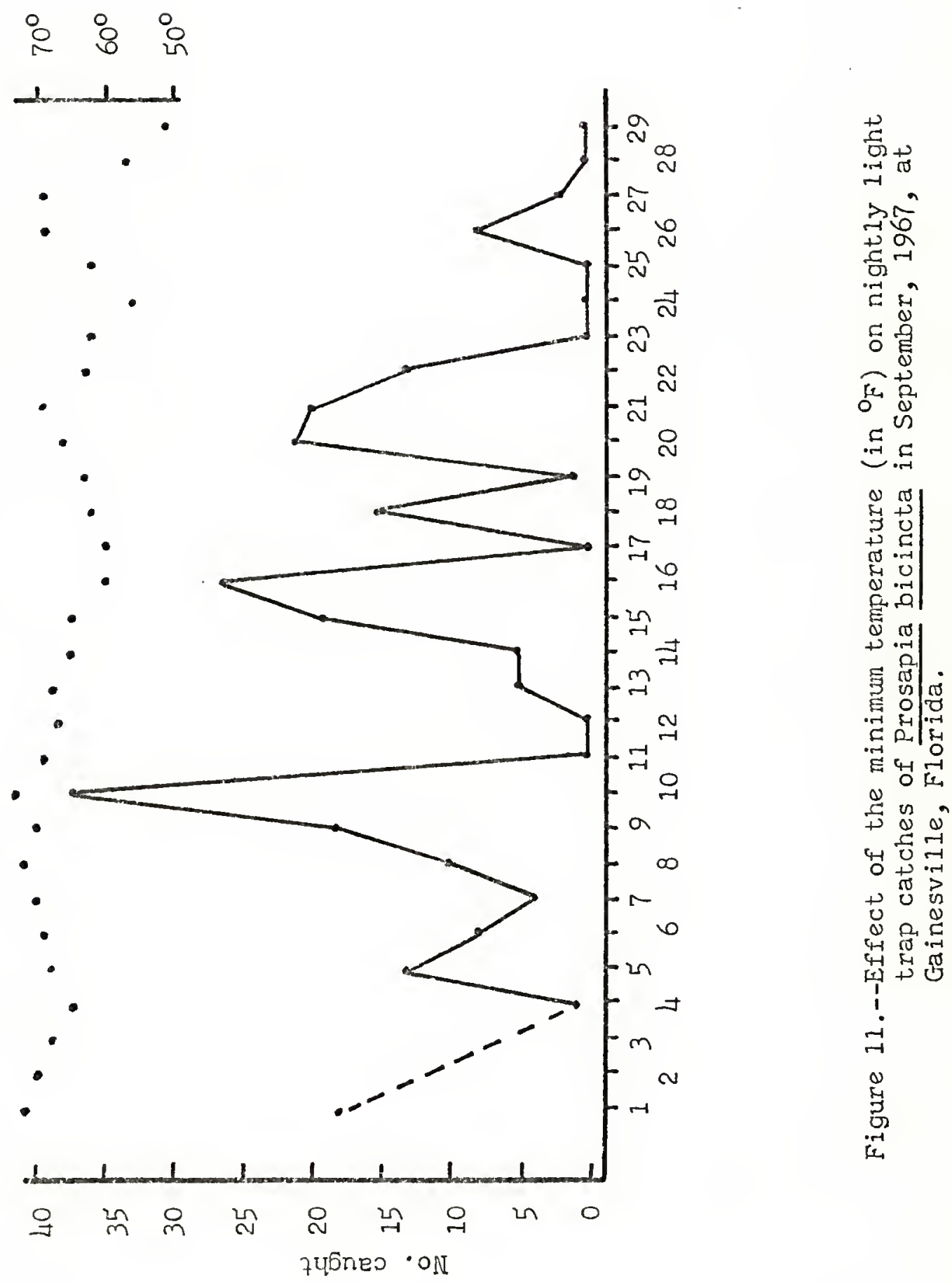
strong flier.

Although the activity of the spittlebug has not been specifically correlated with light intensity, it is not a crepuscular species and has only one peak of activity per night. Also spittlebug catches in light traps do not show any variations due to the effect of moonlight. Effectiveness of Colored Sticky Board Traps

Sticky board traps were rather ineffective for trapping two-lined spittlebugs (Table 6). Only 223 spittlebugs were captured in 26 days at a time when the adult population was at a peak.

As might be expected from the light trap studies, most of the spittlebugs were trapped at night and nearly all were males. Because the adults are most active at night, the color of the board probably had little if any effect. The yellow boards trapped slightly more spittlebugs than the other colors. No significant differences were detected between the directions that the sticky boards faced. A majority of the spittlebugs were trapped at the 6 foot level which seems contrary to the finding that lower light traps caught more spittlebugs. In general, the spittlebugs were probably caught on the sticky boards only haphazardly during flight. Description of Spittlebug Injury to Pangolagrass

Byers and wells (9) proved that only the adults caused injury through the injection of phytotoxic salivary substances. They described the progression of symptoms on Coastal bermudagrass. Age and sex were not important in the ability of the adult to produce injury (8).

$\underline{\text { P. bicincta }}$ is primarily a pest of pangolagrass in Central Florida. Field observations in that area indicated it is the adult that danages pangolagrass. Large populations of nymphs go unnoticed until the adults emerge and cause injury. 
To determine the progression of symptoms of spittlebug damage, individual adults were confined about 6 in. above the soil on stems of potted pangolagrass in the seed-head stage. This was replicated 12 times. Maerz and Paul (39) color charts were used to determine the colors in the description.

Adults caused injury symptoms within 24 hours. Symptoms first appeared on the blades immediately above the feeding site, then progressed to the next highest blade. Injury to a single blade began at the terminal end. The tip turned yellow (9-K4) and this discoloration proceeded basally. Yellowing was followed by the blade turning brown (19-J1) and curling. Where the stem forked above the feeding site, only 1 fork showed symptoms. The blades died in 1-3 days and the stem in 3-4 days. Effects of Damage on Nutritive Value of Grasses

Washbon (91) found that St. Augustinegrass damaged by the two-1ined spittlebug was about $20 \%$ lower in protein than undamaged grass. In August, 1968, grass was collected from areas of spittlebug damaged and undamaged areas of the Range Cattle Station. Two samples from each area were weighed in the field and oven dried for 48 hours. The wet weight was determined and the samples were ground up in a wiley mill. A standard proximal analysis was performed on the samples by M. M. Sharpe, Division of Chemistry, State of Florida Department of Agriculture, Tallahassee. Table 7 summarizes the results of that analysis.

Spittlebug damaged grasses contained less moisture on a wet basis than uninjured grasses. This is reflected in the field by the brown dried appearance of damaged grass. Spittlebug damaged grasses contained considerably less protein than undamaged grasses. Damaged pangolagrass contained about $45 \%$ less protein than the undamaged samples and about $17 \%$ 
$-57-$

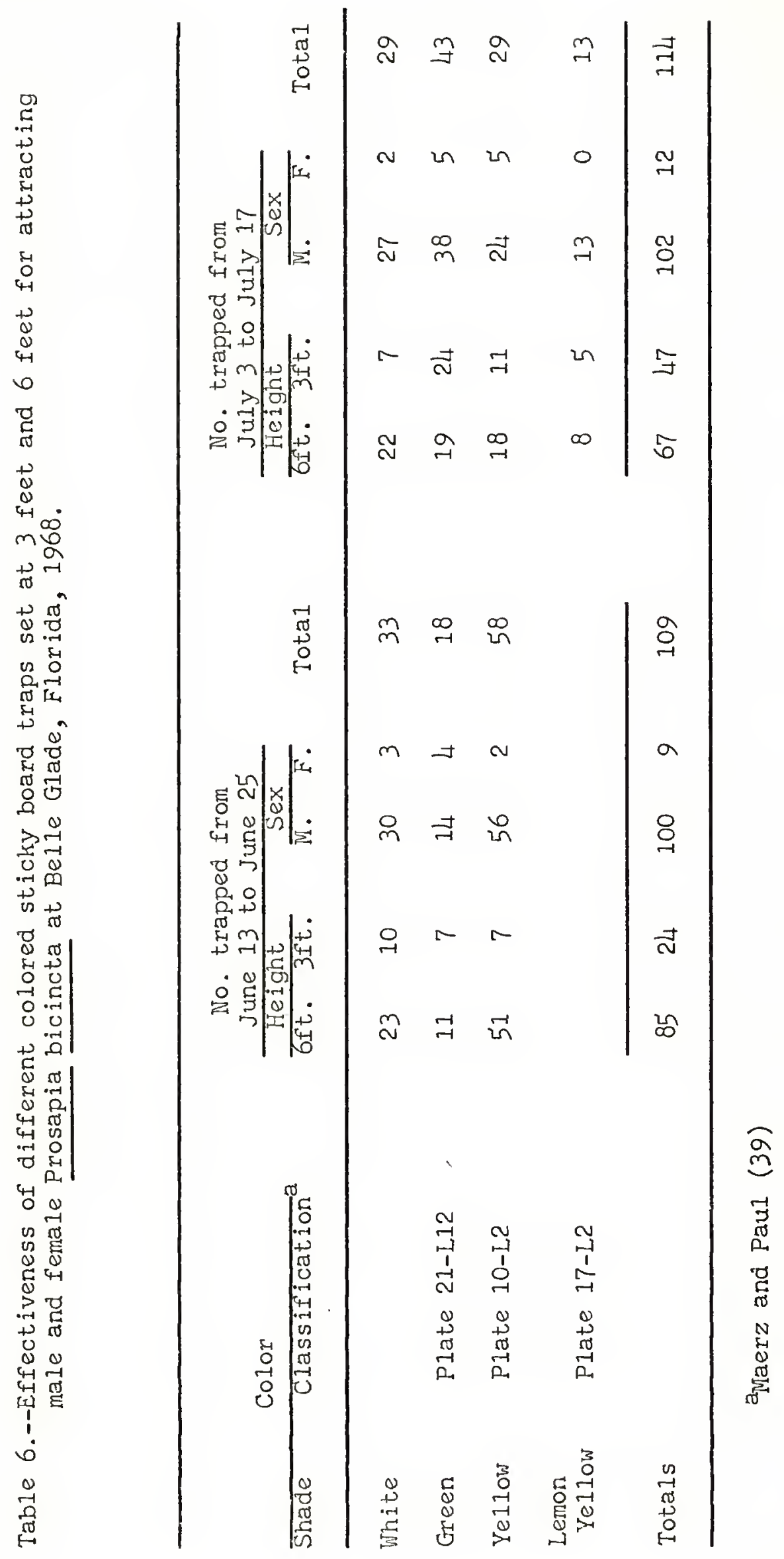


Table 7.--Effects of damage by adult Prosapia bicincta on the nutritive value of pangolagrass and bermudagrass.

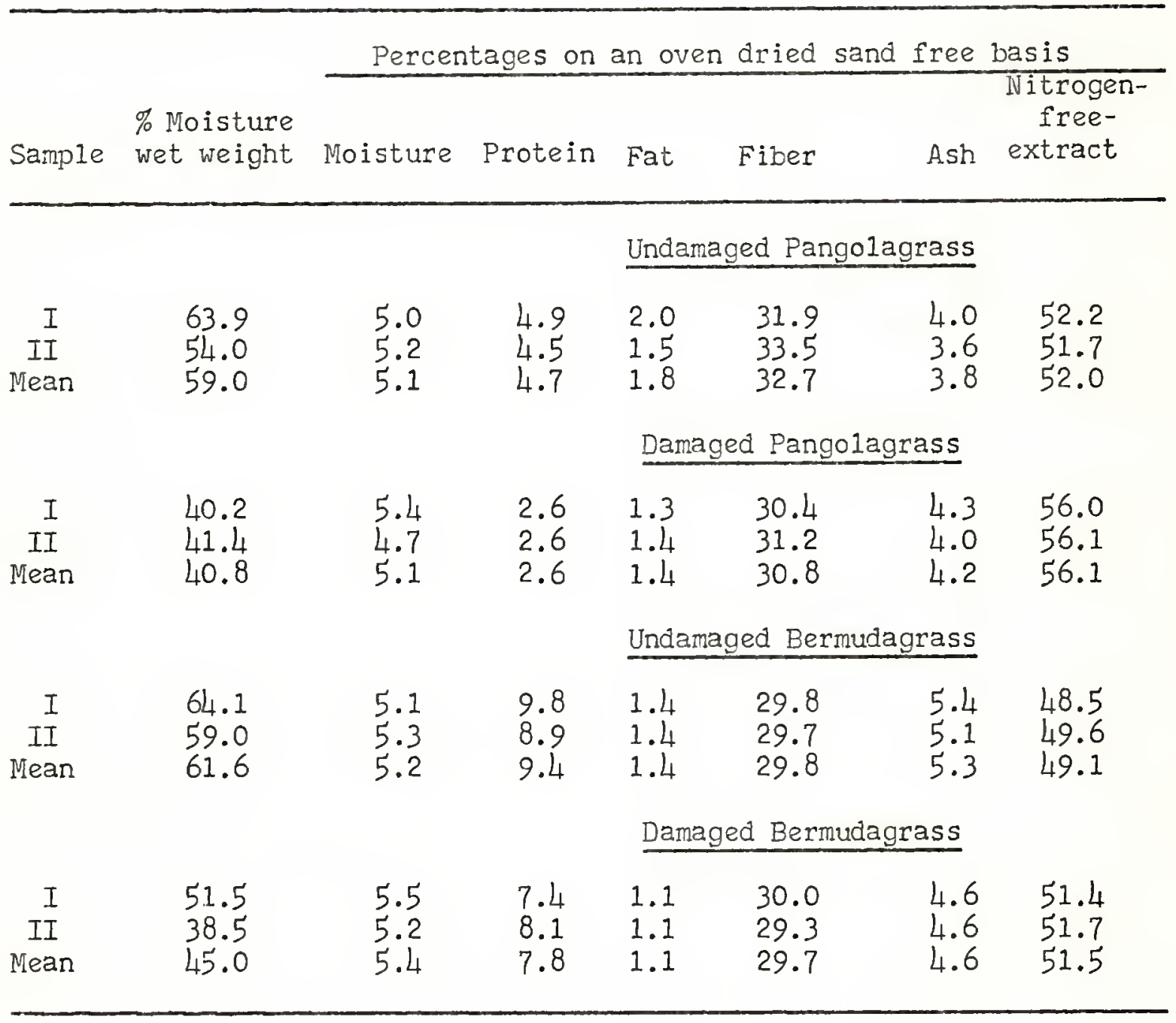


less protein in the damaged bermudagrass.

Economic Importance of P. bicincta

Washbon (91) showed that infestations of spittlebugs caused serious nutritive depletions in St. Augustinegrass. Similar results were obtained for pangolagrass and bermudagrass in this study. Although yield data are not available specifically for $\underline{P}$. bicincta, observations on other sucking pests indicated they can reduce the gross yield of pasture grasses often in excess of $50 \%$ (26). So the result of spittlebug injury is less grass with less nutrients.

Heavy spittlebug infestations and the resulting damage lowers the palatability of grass (31), reduces root production and sod reserves (58), is related to weed invasion into improved pastures (28), and may be important in the incidence of gray leaf spot disease on pasture grasses (91). Spittlebug damaged pangolagrass may be more susceptible to winter killing than healthy grass.

Reports of spittlebug damage in Florida have occurred from 2 basic problems. First, damage to pangolagrass occurs generally to tall heavy stands during wet years. This thickly matted grass provides the optimum habitat for spittlebugs. When pangolagrass is held in this condition for later harvesting or for winter pasture, spittlebugs build up to the point where damage occurs. Ta11 grass pastures are especially susceptible to injury in August and September.

Secondly, newly planted St. Augustinegrass is easily damaged and killed by adult spittlebugs. This usually occurs when the new grass is planted in August and September. We11 established mature St. Augustinegrass seems to be very tolerant to spittlebug feeding because it takes a very high adult population to produce injury. 


\section{Control}

\section{Light Traps}

Cardin (11) first suggested using light traps to control $\underline{P}$. bicincta in 1917. In Florida up to 10,000 spittlebugs per night were captured by a single light trap set in a heavily infested area. Even so, many adults have been observed resting on grass around a light trap in the early morning indicating some inefficiency in trapping. Sweeping of those spittlebugs showed they were predominantly males.

When light traps 50 feet apart were run in a highly infested pasture, each trap caught about the same number of spittlebugs that it would have caught if run separately. No data were collected on the number of traps per unit of land that would be necessary to reduce the spittlebug population.

Since mostly males are attracted, lights might be important in the future should a chemosterilization program ever be developed against the two-1ined spittlebug.

\section{Cultura1 Control}

Cultural control generally involves the use of management, harvesting, and machinery as preventive measures which are usually employed in advance of the time that damage may occur. Often they are the only control measures that can be employed profitably with crops of great acreage and low unit value, such as pastures.

For cultural control to succeed, it is necessary to understand the Iife history and habits of the insect in question. Practices are then directed against some particularly weak point in the life cycle or adaptation of the insect pest to its environment.

Beck (3) observed that burning Coastal bermudagrass in April gave 
$100 \%$ control of $\underline{\mathrm{P}}$. bicincta in Georgia. Furthermore, mowing and raking also reduced the nymphal population. From these observations, Beck concluded that the insect may be substantially controlled by good pasture management and efficient use of the grass as forage. Hodges, et al. (31) suggested heavy grazing or removal of spittlebug infested pangolagrass for hay or silage as a means of controlling or reducing spittlebug damage. During many attempts to raise spittlebugs under artificial conditions, the eggs were easily desiccated and the nymphs killed by low moisture or humidity conditions. Undoubtedly, under field conditions many eggs fail to hatch and nymphs fail to survive unless they are protected from desiccation. Any cultural practice which would lessen or prohibit the protection provided by the heavy thick canopy of grass should reduce the spittlebug population

Burning.--Beck (3) found that spring burning destroyed the overwintering eggs of $\underline{P}$. bicincta in Coastal bermudagrass at Tifton, Georgia. However, pangolagrass apparently is injured by burning (31). Bermudagrass returns from rhizomes after burning but pangolagrass is stoloniferous and cannot withstand burning to the degree required for removal of all debris and above ground vegetation.

Strayer (57) recommends burning Coastal bermudagrass pastures in late February or early March for spittlebug control in Florida. If the pasture contains clover, it can be burned late in the fall. Mowing.--In an experiment where pangolagrass was cut with a rotary mower to a height of 4 in., nymphs were significantly reduced (Table 10). However, the percent control was very low. Mowing may give some control of early instars which are more susceptible to desiccation. It is employed primarily to harvest the forage to prevent further loss of nutritive value. 
Pastures which have not had the sod disturbed for a number of years have a great deal of litter and debris at the soil surface which provides added protection for spittlebug nymphs. Under these conditions it seems unlikely that mowing the grass to height practical under normal agronomic practices (4-6 in.) would greatly reduce the nymphal population.

Adult spittlebugs tend to move out of short grass. Mowing' at the times when adult populations are highest should inhibit spittlebug injury. Grazing.--Heavy grazing to rapidly remove spittlebug infested grass is recommended whenever animal numbers and size of area permit. Rapid removal of herbage is essential as it opens the stand and allows access to birds and promotes drying of the grass crowns. Close grazing to prevent heavy growth of grass in midsumer is one method of controlling spittlebugs (31).

In August, 1968, infested pastures at the Range Cattle Station averaged about 6 nymphs per square foot under grazing compared to 17 per square foot in non-grazed areas.

In central Florida, pangolagrass probably can be grazed extremely close during the months spittlebug damage is most common (August and September) and still produce pasture for winter. A pasture grazed until September 1 should return to the head stage by middle October ( 45 days); if grazed until October 1, it should be in the head stage in 60 days, thus providing some winter pasture if fertilized and deferred.

Dense bunch grasses (vaseygrass and smutgrass) may increase spittlebug problems even in grazed improved pastures. The high level of palatability of pangolagrass often results in cattle grazing it in preference to other vegetation, thus allowing the bunch grasses to retain the dense habitat favorable to spittlebug eggs, nymphs, and adults. 
Harvesting.--Harvesting spittlebug damaged grass for hay or silage prevents further quality decline and usually brings spittlebug activity to a halt (31). Removing the grass is especially efficient in controlling the early instar nymphs. Scme later instars are undoubtedly also killed but many are able to resist desiccation and develop to adults. The adults migrate to taller grass, then return when the lush new growth again affords food and protection.

Harvesting in late summer should prohibit damage and still provide winter pasture as outlined under the section on grazing. If the grass is harvested in August, it may be profitable to not fertilize it for about a month. The slow growing short grass is then not attractive during the period when adult spittlebug populations are highest and overwintering eggs would not be deposited in the field. Pastures fertilized after the spittlebug population declines should develop for winter use. Renovation.--Renovated pangolagrass pastures usually are not subject to spittlebug damage for at least 2 years. The soil surface in these pastures is void of litter and debris conducive to spittlebug development. Some time is necessary before conditions typical of an undisturbed sod return and spittlebugs develop high populations again in the field. Chopping and discing.--Chopping or discing spittlebug infested pastures destroys the eggs, disturbs the sod, and opens the stand for drying. On August 15, 1968, a pangolagrass pasture at the Range Cattle Station which had been chopped on July 1 averaged less than 1 nymph per square foot compared to 17 per square foot in non-chopped areas. Planting time...-Spittlebugs have caused serious damage to St. Augustinegrass planted in August and September. Planting in the spring (April to June), should allow St. Augustinegrass to become well established before the 
Periods of flight activity.--A light trap which divided the nightly catch into hourly samples was used to determine periods of flight activity. Table 5 sumnarizes the results from 9 nights at Belle Glade. Sone spittlebugs were trapped during every hour of the night but about $7.1 \%$ of the total were captured by $11 \mathrm{p} . \mathrm{m}$. and $85 \%$ were taken by 12 midnight.

Figure 10 graphically depicts the flight activity of $\underline{P}$. bicincta according to sex. The activity of the females was similar to the male and there was only 1 peak of activity per night for both sexes. Effects of weather conditions on 1ight trap catches.--As would be expected weather conditions can greatly influence light trap collections of spittlebugs. The minimum night time temperature is one important source of variation. Figure 11 shows how minimum temperatures effect the nighttime activity of $\underline{\mathrm{P}}$. bicincta as determined by light trap collections. In general, catches are greatly reduced when the minimum temperature is below $65^{\circ} \mathrm{F}$ and spittlebugs are rarely caught below $60^{\circ} \mathrm{F}$. To have much effect on the nightime activity, low temperature must occur within the 4 hour period after sunset. Temperature probably influences spittlebug activity only in May, September, and October.

Precipitation has little effect on catches except when it occurs before midnight. Rain during these hours can greatly reduce light trap catches. For example, 3,140 spittlebugs were captured on June 12, 1968, at Belle Glade; rain began the next day at dark and continued into the night resulting in the capture of only 455 spittlebugs; the following night the catch was back up to 2,423.

No quantitative data were collected on the effect of winat velocity or direction on light trap catches. However, strong winds should reduce flight activity because the two-1ined spittlebug is not a particularly 
adult spittlebug population peaks. Well established St. Augustinegrass seems able to withstand high spittlebug infestations in June and July without injury.

Pangolagrass is normally planted to take advantage of the rainy months and new plantings have not been effected by spittlebugs. Grass-1egume mixtures.--Two-1ined spittlebugs have not been reported on or the adults causing injury to legumes. Mixed pastures may lessen spittlebug damage. Grass varieties.--Two factors appear to influence the probability of spittlebug injury to grasses; the attractiveness of grasses to spittlebugs, and the tolerance of grasses to spittlebug injury. All of the grasses in the trial except the Digitaria crosses have previously been recorded as hosts. Thus they are assumed to be attractive and would make good hosts should the grass be extensively planted in the future.

However, some of the grasses seem to be more tolerant than others (Tab1e 8). Digitaria decumbens designated USDA P. I. \#111110 is widely planted as pangolagrass in Florida and is used as a standard for comparison in this study. Two species of Brachiaria and 2 introductions of Hemarthria altissima showed little or no damage. Two Digitaria crosses were also less damaged than pangolagrass.

From many field observations the major improved pasture grasses in Florida can be ranked from the most susceptible to spittlebug injury to the least as follows: bermudagrass, pangolagrass, St. Augustinegrass, and bahiagrass.

The tolerance some grasses show to spittlebug feeding may be influenced by environmental factors. Pangolagrass is injured in late summer but not by the $1^{\text {st }}$ generation adults in June. It is in a rapid vigorous 
state of growth at that time. But by late sumer, grasses on mineral soils undergo a severe water stress. Under water stress, pangolagrass appears to be more susceptible to injury by the $2^{\text {nd }}$ generation of spittlebugs. In contrast, St. Augustinegrass in the Belle Glade area undergoes water stress later and of a less severe nature because of the water holding capacity of the organic soils. This may contribute to St. Augustinegrass' tolerance to spittlebug injury.

Chemical Control

A perusal of the literature shows that only a few insecticides have any promise of controlling $\underline{P}$. bicincta adults and nymphs in tall grass. Nearly all of this information comes from experiments conducted in South Carolina and Georgia on Coastal bermudagrass. Little chemical control information is available for Florida.

Because of the small plots and the mobility of the adults, usable control data were difficult to obtain. Only data taken within 3 days after application were considered valid for the adults. Nymphs were not sampled until at least 48 hours after application to allow time for the spittlemasses to disintegrate if control was effected. Treatments against the nymphs were considered ineffective if $85 \%$ control was not obtained. 1967 Experiments.--Experiment 1.--Granular applications of chlordane, dieldrin, and parathion at $31 \mathrm{~b} \mathrm{AI/acre} \mathrm{were} \mathrm{effective} \mathrm{in} \mathrm{controlling} \mathrm{the}$ $1^{\text {st }}$ generation nymphs (Table 9). A residual insecticide applied at the right time in the spring should control the new nymphs as they search for a suitable feeding site. A thorough knowledge of the climatic factors that initiate the hatching of the eggs is needed so that applications can be timed properly.

Experiment 2.--In Table 10 plots which were mowed and treated with 
Table 8.--Visual rating of damage to grasses by Prosapia bicincta in a field trial. Ona, Florida. October 11, 1968.

\begin{tabular}{|c|c|c|}
\hline Species & $\begin{array}{l}\text { USDA } \\
\text { P.I. No. }\end{array}$ & $\begin{array}{c}\text { Mean Visual } \\
\text { Rating* }\end{array}$ \\
\hline 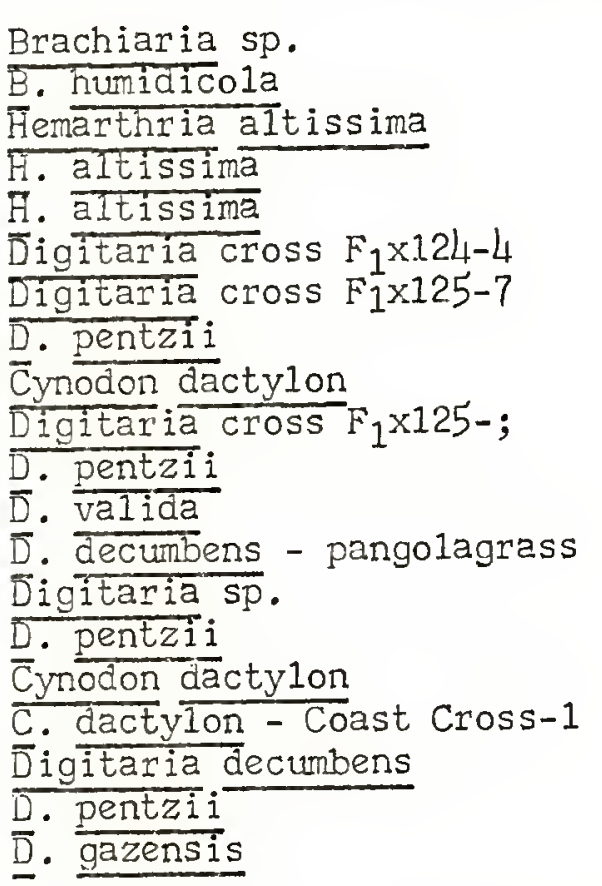 & $\begin{array}{l}299498 \\
257678 \\
299993 \\
299994 \\
299995 \\
\\
299828 \\
224152 \\
299753 \\
299810 \\
111110 \\
300935 \\
279651 \\
225957 \\
299601 \\
299602 \\
299637\end{array}$ & $\begin{array}{l}1.00 \mathrm{a} * * \\
1.00 \mathrm{a} \\
1.13 \mathrm{a} \\
1.25 \mathrm{a} \\
4.00 \mathrm{~b} \\
4.00 \mathrm{~b} \\
4.25 \mathrm{bc} \\
4.75 \mathrm{bcd} \\
5.50 \mathrm{cde} \\
5.50 \mathrm{cde} \\
6.00 \mathrm{def} \\
6.00 \mathrm{def} \\
6.00 \mathrm{def} \\
6.00 \mathrm{def} \\
6.50 \mathrm{efg} \\
6.50 \mathrm{efg} \\
7.00 \mathrm{efgh} \\
7.16 \mathrm{fgh} \\
7.67 \mathrm{gh} \\
8.25 \mathrm{~h}\end{array}$ \\
\hline
\end{tabular}

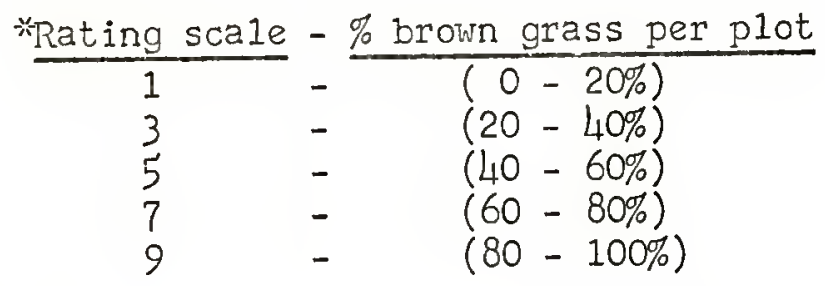

* Wreans followed by the same letter are not significantly different at the $5 \%$ level, (Duncan's multiple range test). 
Table 9.-- Chemical control of the first generation nymphs of Prosapia bicincta in pangolagrass at the Range Cattle Station, Ona, Florida, 1967. Experiment 1.

\begin{tabular}{lcc}
$\begin{array}{c}\text { Treatment } \\
\text { May 16, 1967 }\end{array}$ & $\begin{array}{c}\text { Lb } \\
\text { AI/acre }\end{array}$ & $\begin{array}{c}\text { June 18 } \\
\text { Nomphs } / \mathrm{ft} .^{2}\end{array}$ \\
\hline Chlordane 10\% G & 3.0 & 0.00 \\
Dieldrin 10\% G & 3.0 & 0.00 \\
Parathion 10\% G & 3.0 & 0.00 \\
Check & 0.0 & 2.00 \\
\hline
\end{tabular}




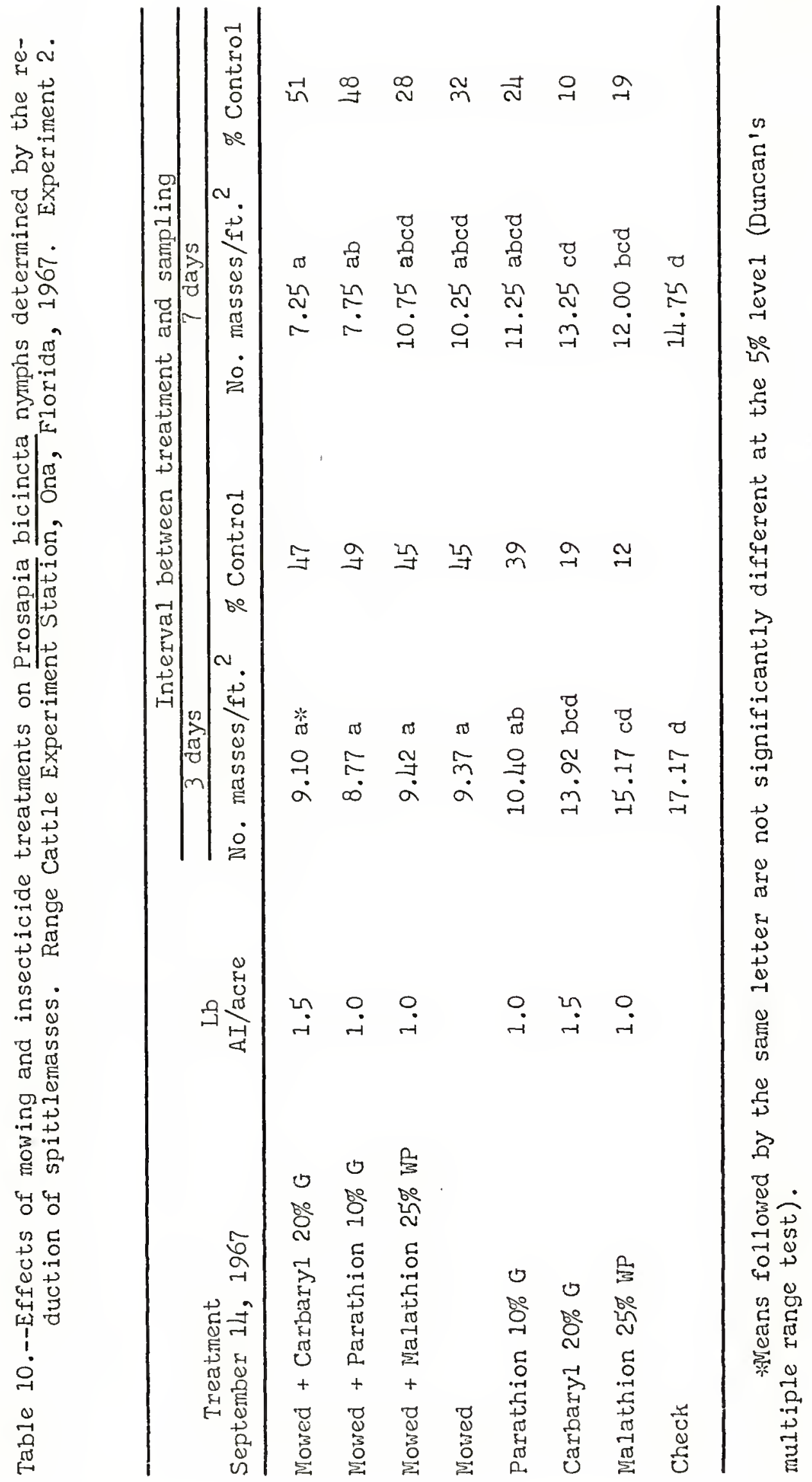


carbaryl and parathion contained significantly fewer nymph than check plots. Even so, the percent of control was very low. This suggests that the materials used in this experiment, which are among those cleared for use on pastures, will not control the nymphs even in short grass.

Experiment 3.--Examination of Table 11 shows that applications of azinphosmethyl, even at $0.5 \mathrm{lb}$ AI/acre, initially controlled the adults. After 6 days, the 1, 1.5, and $21 \mathrm{~b}$ AI/acre rates showed significant control. Data recorded 16 days after application are probably not reliable. Nymphs were not controlled at any of the rates used in this experiment.

Experiment 4.--A11 of the materials except Dyfonate provided significant control of the adults at the 2 day interval (Table 12). Aldicarb, Dursban G, Supracide, and Dursban EC gave 89\%, 89\%, 89\%, and $86 \%$ control of the adults respectively. Data collected at the 12 day interval were not considered sound.

Aldicarb, carbofuran, and Bayer 37289 at 2 1b AI/acre were the best materials used in the test against the nymphs (Table 13). The former 2 are systemic carbamates. Dursban at 0.2 ib AI/acre and Mobam at 2 1b AI/acre also gave adequate control (above $85 \%$ ). 1968 Experiments.--Experiment 1.--The systemic insecticide, phorate, at 1 and $21 \mathrm{~b}$ AI/acre initially gave $92 \%$ and $96 \%$ control of the adults respectively (Table 14). Table 15 shows that these same rates gave excellent control of the nymphs through 27 days after application.

No phytotoxicity was noted at any of the rates. At the higher rates, phorate noticeably stimulated the growth of the grass beyond that which could be attributed to insect control. In 2 weeks grass in these plots was greener and taller than grass in the check plots.

Experiment 2.--None of the materials gave significant control of the nymphs (Table 16). Materials in spray formulations apparently do not reach 


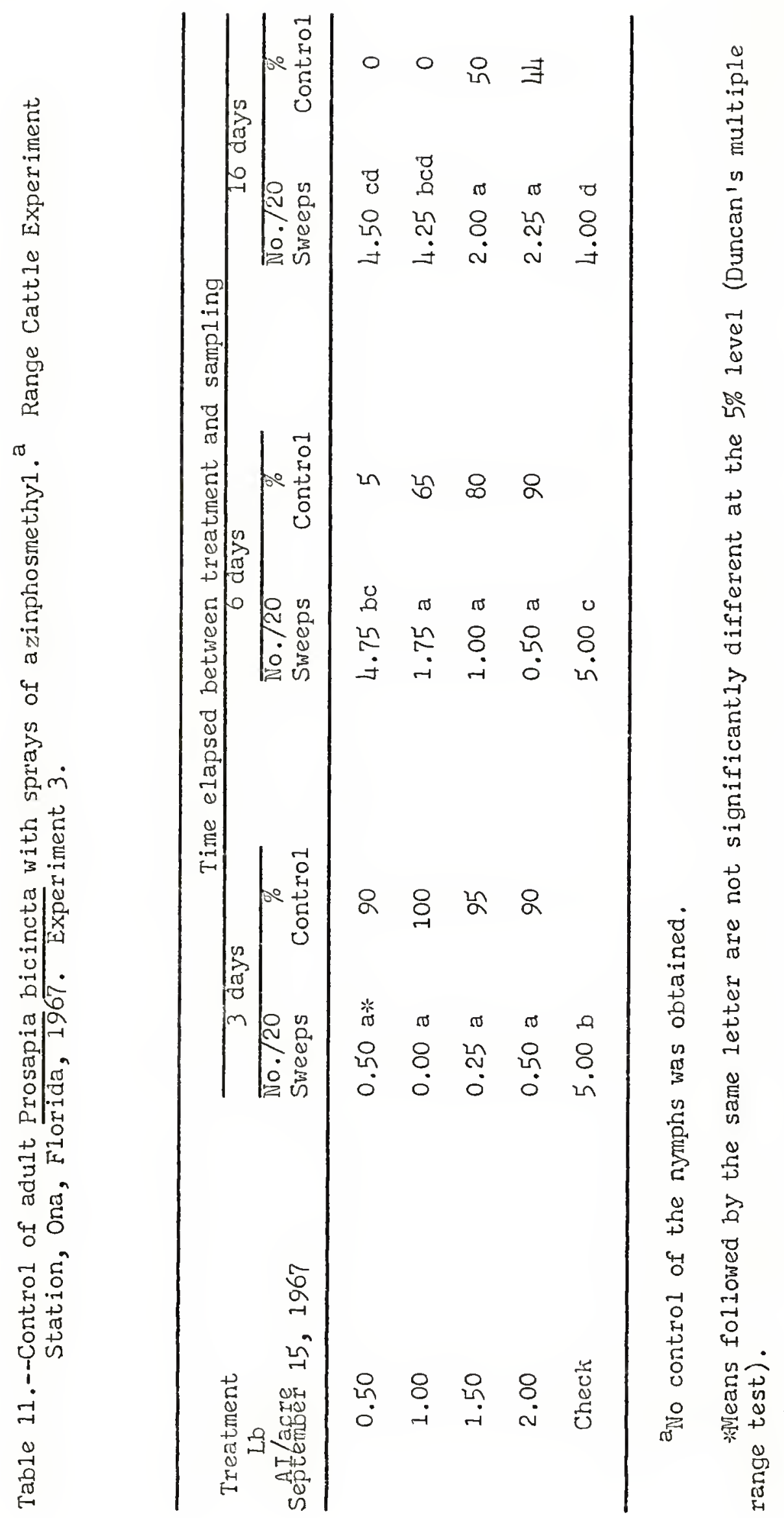




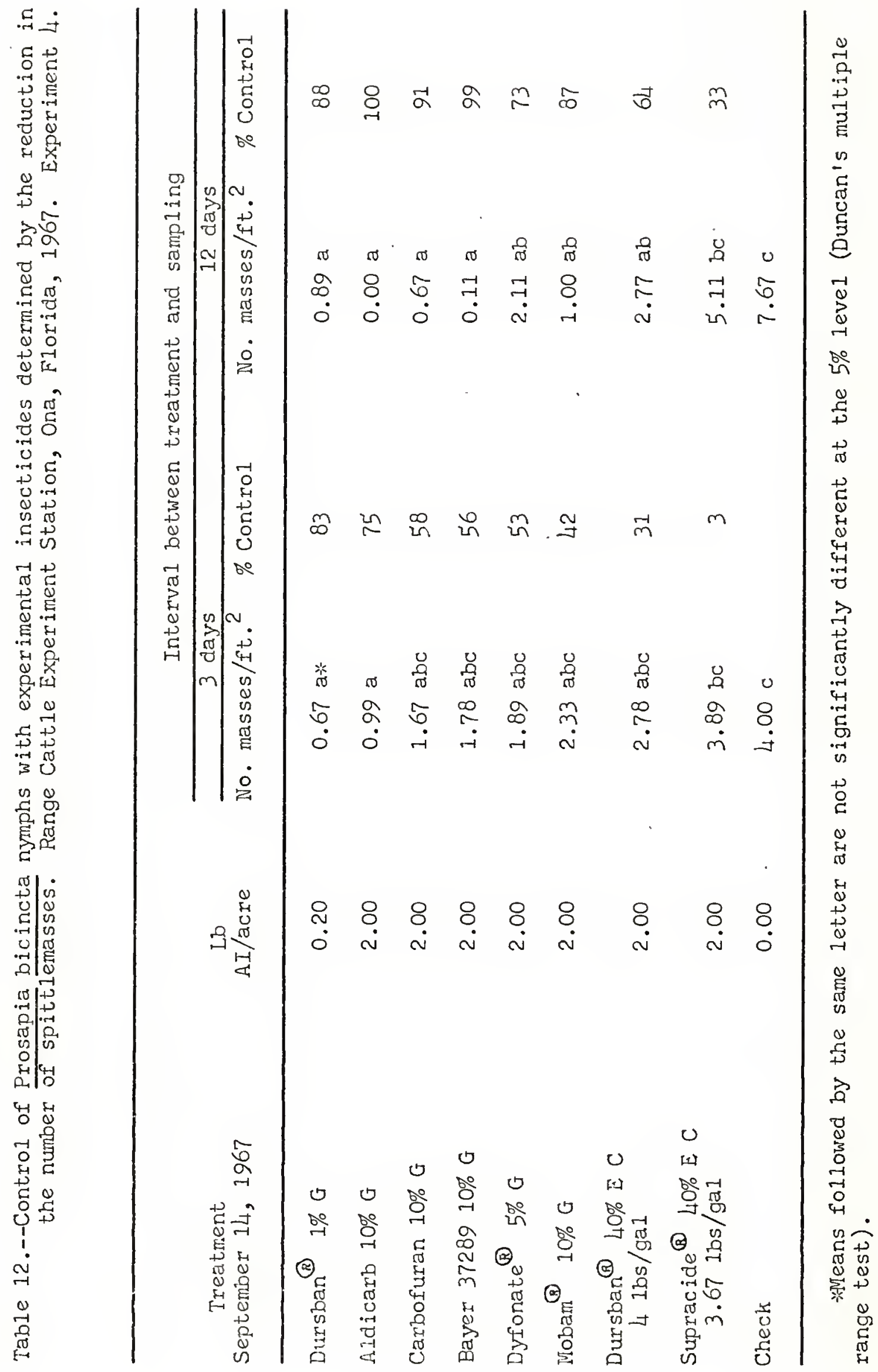




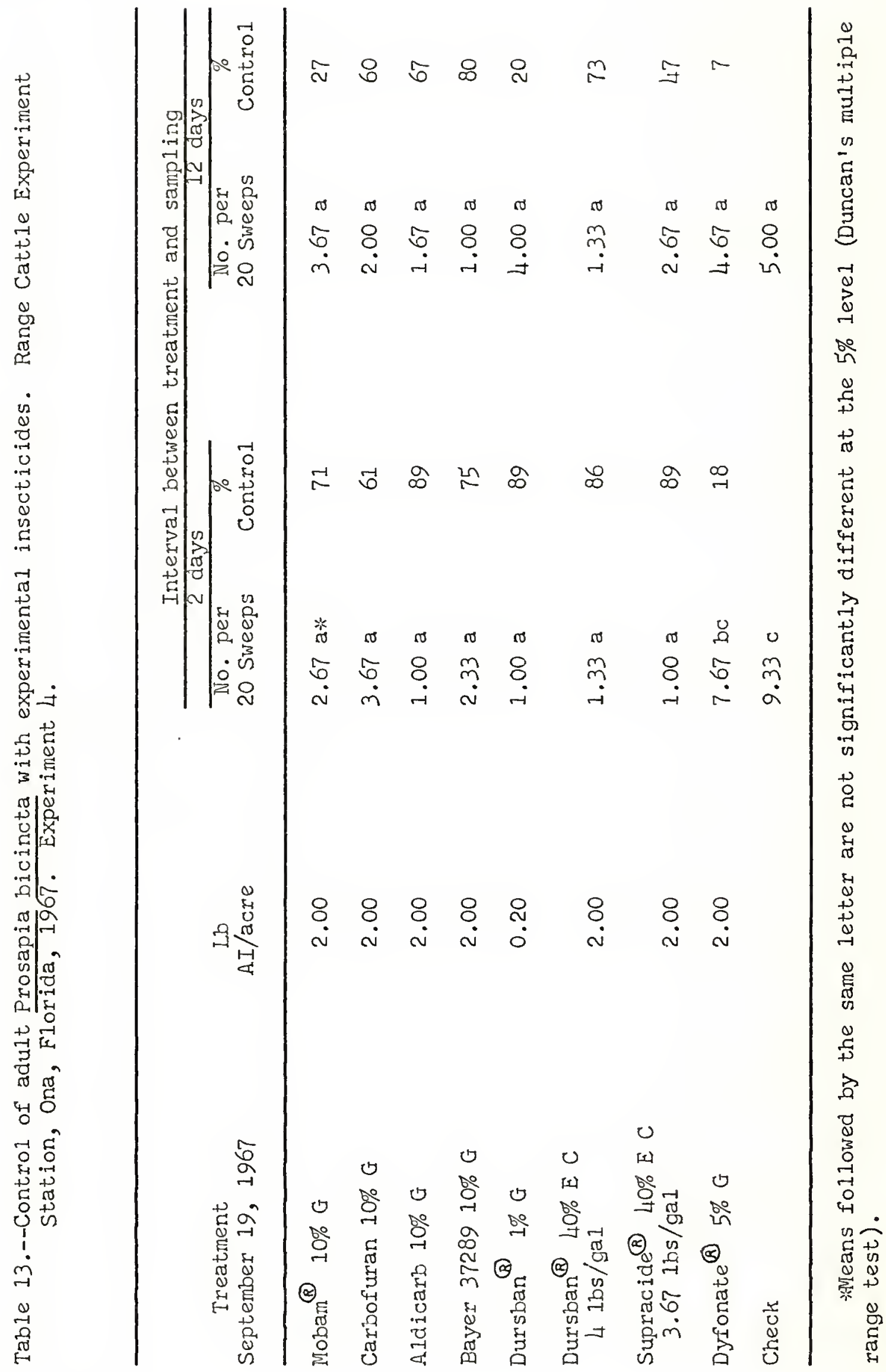




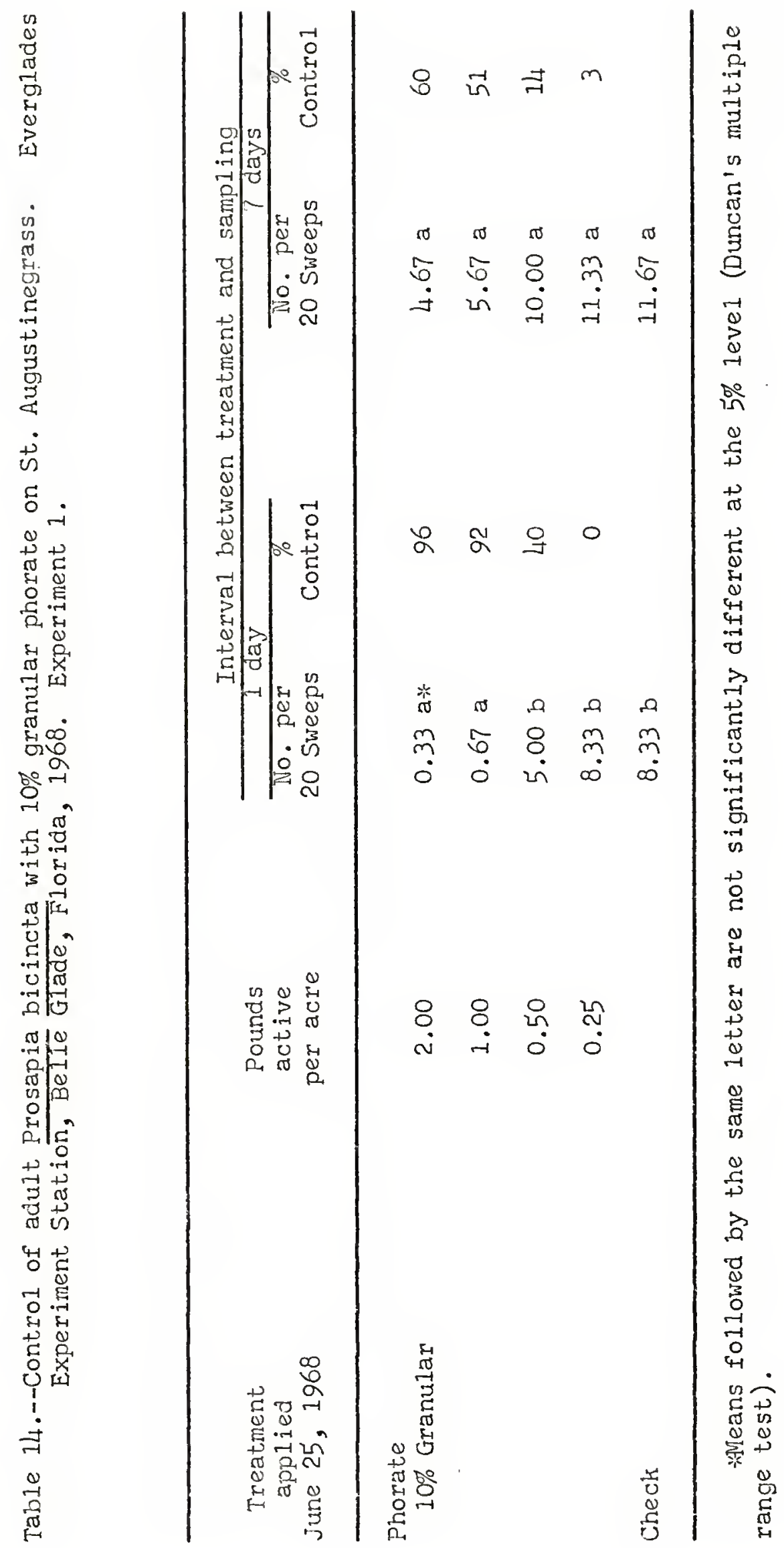




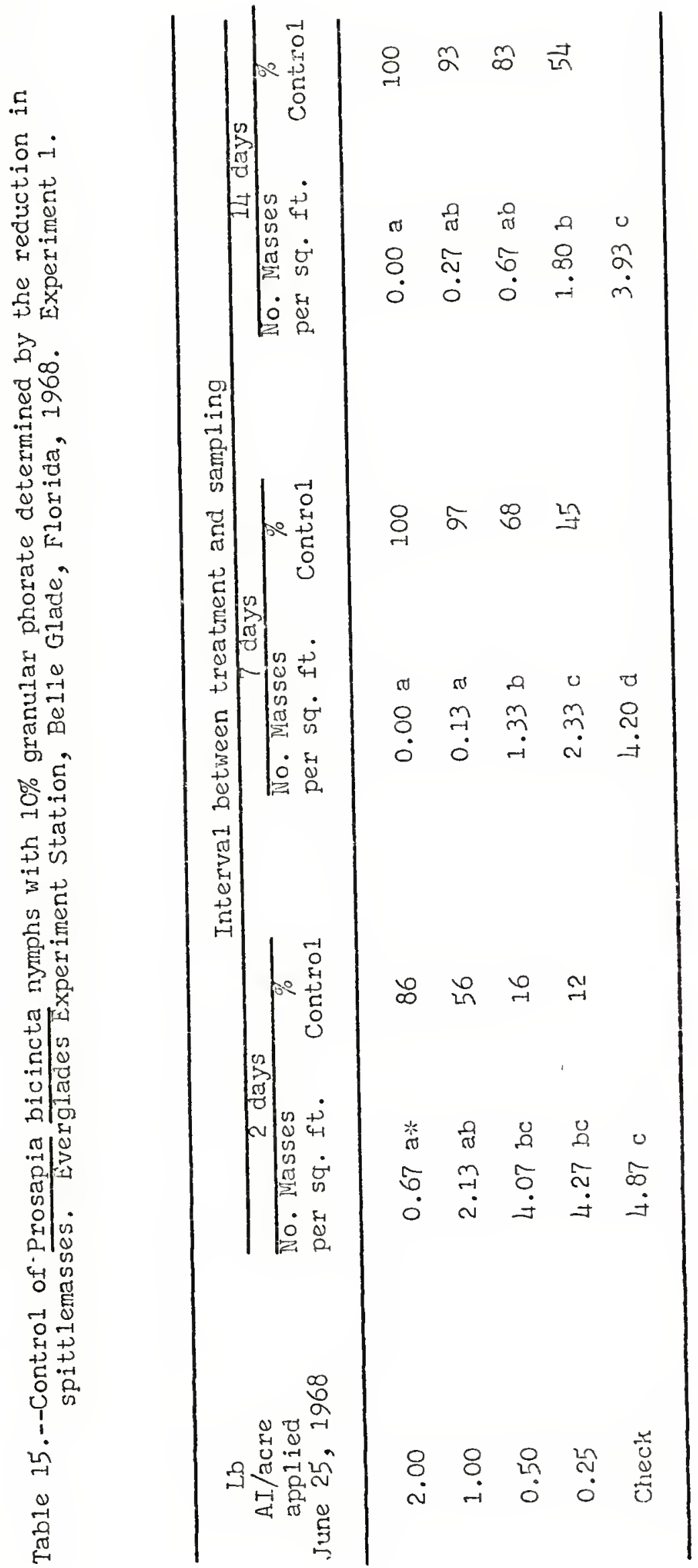



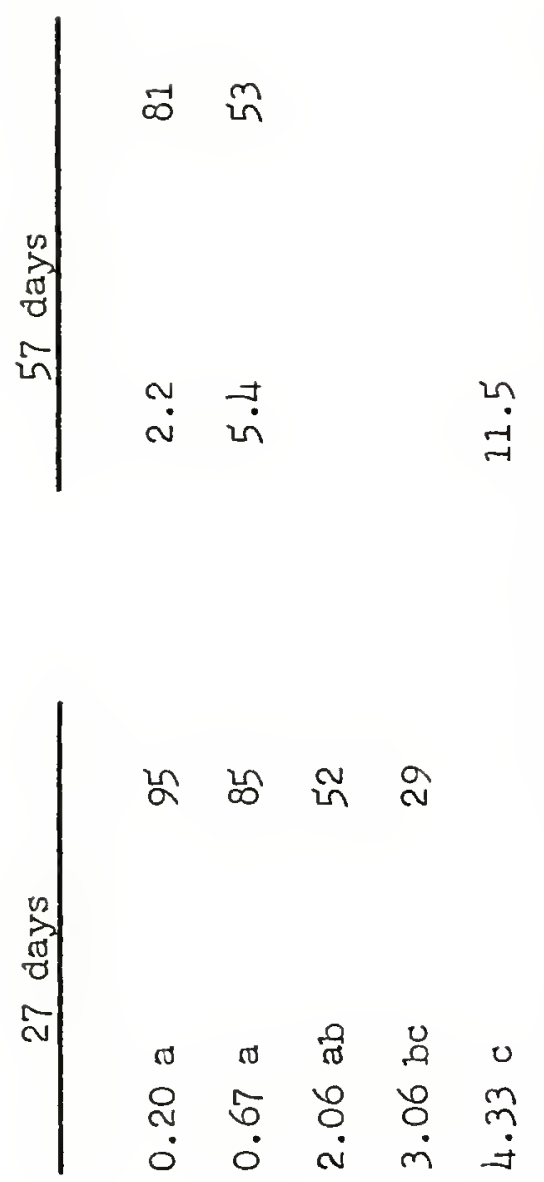

นึ่

$\stackrel{乛}{\ddagger}$

$+$

苟

空

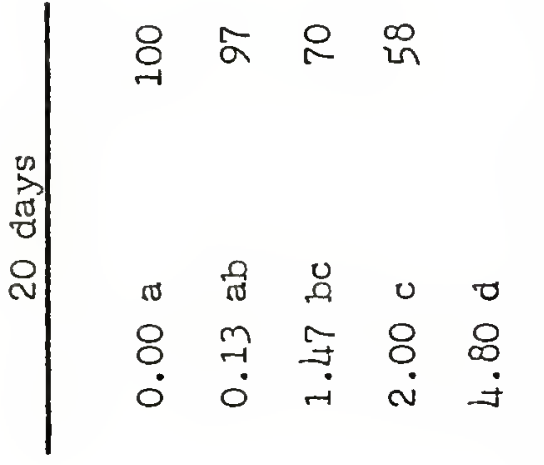

음

I

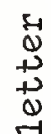

薦

站

吕

0
0
0
0
-1
-1
0
0
$4-1$

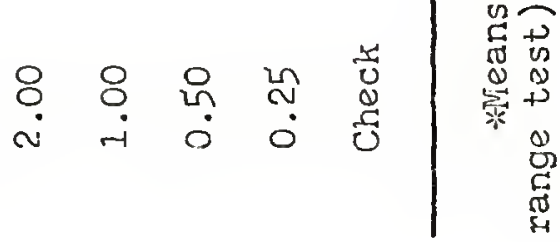




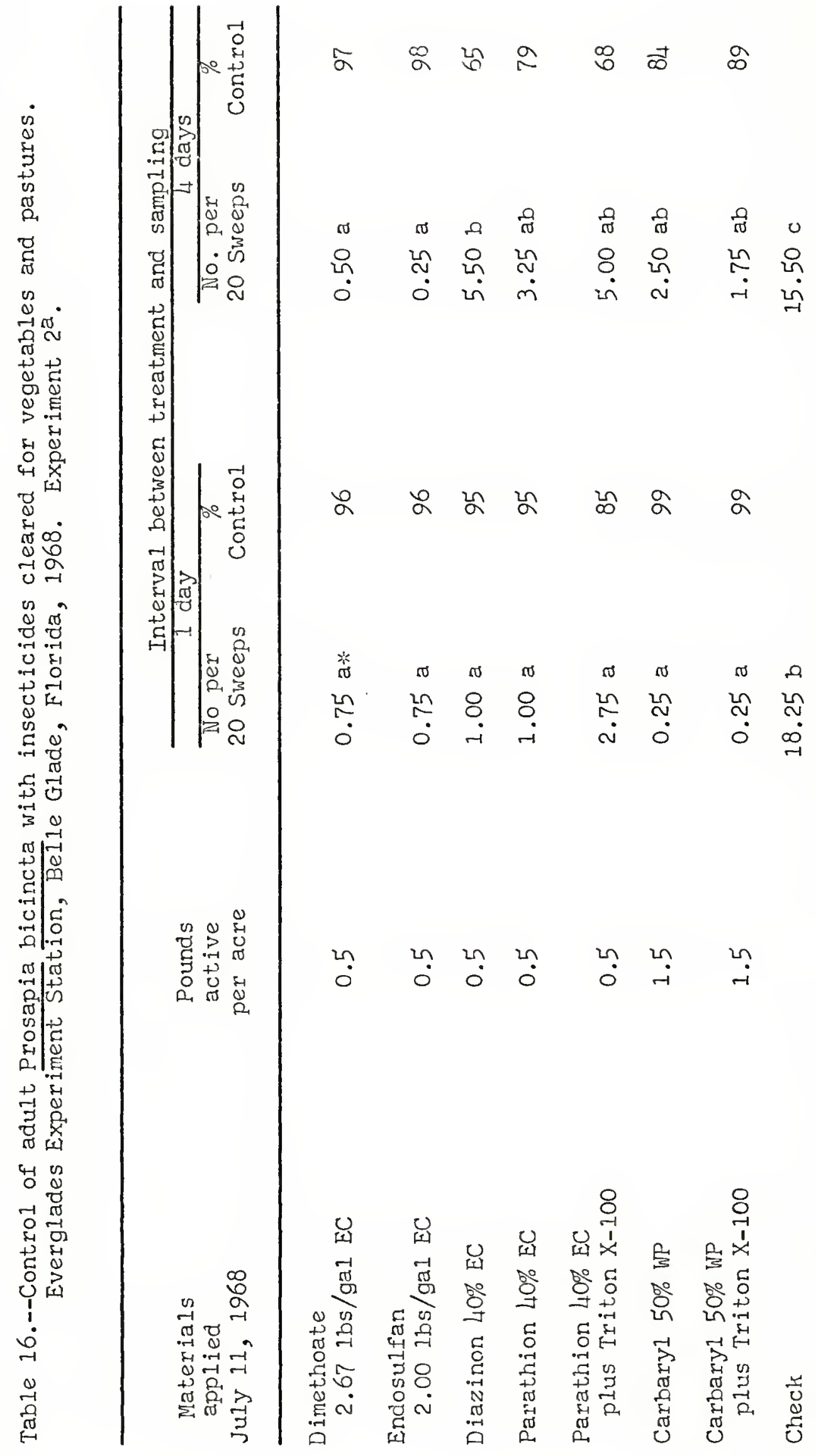




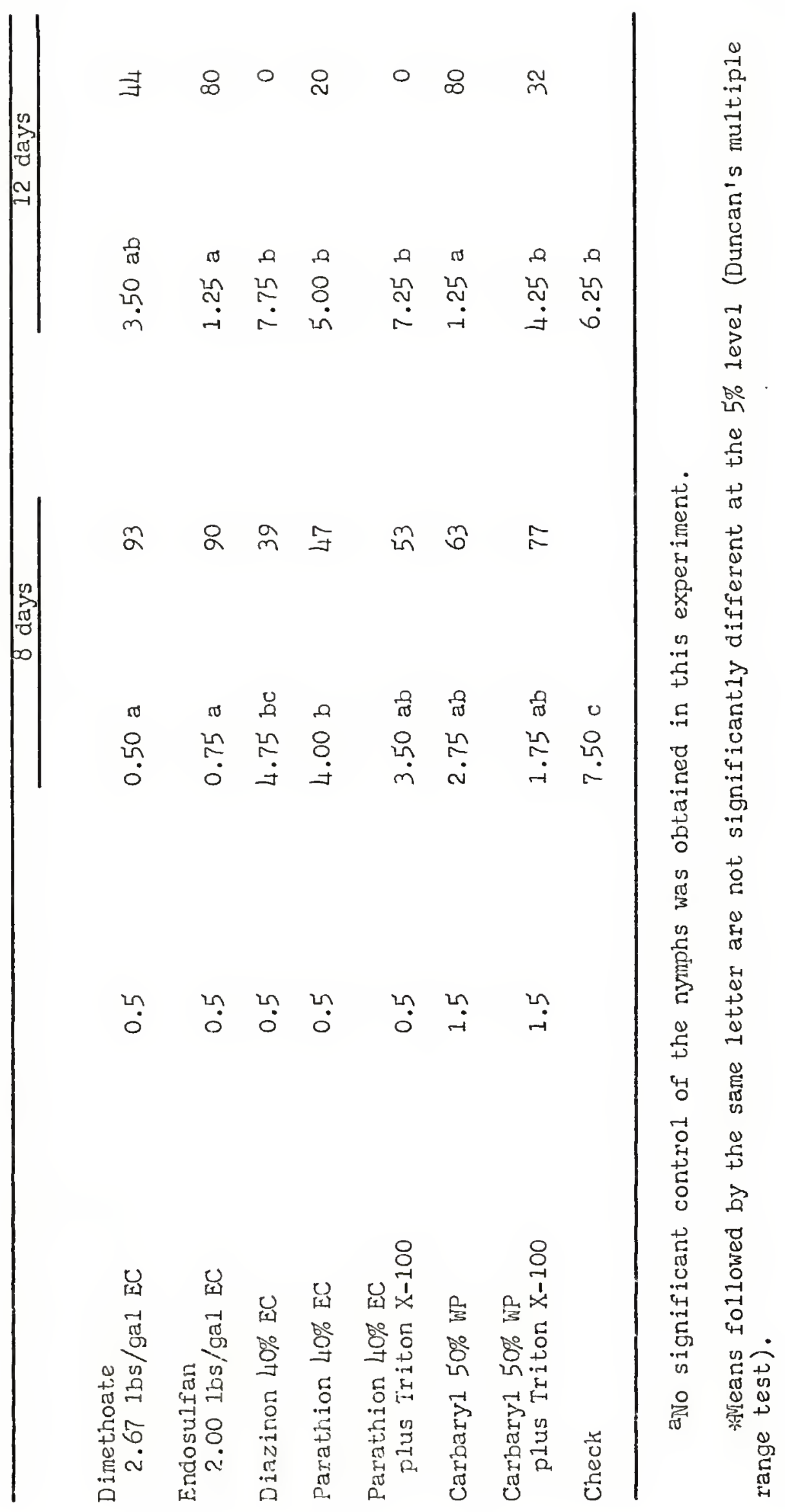


the nymphs. The addition of Triton X-100 and application of 100 gal of water per acre did not increase the effectiveness of either parathion or carbaryl against the nymphs. All of the treatments provided good control of adults at the 1 day interval. Results are erratic after the first day.

Experiment 3.--Only aldicarb and Dursban demonstrated significant control of the adults after 1 day (Table 17). No significant control was obtained at the 11 day interval even though aldicarb showed 93\% control. Materials applied in the granular formulation may not be as effective against the adults as they might be when applied as sprays.

Aldicarb at $0.51 \mathrm{~b}$ AI/acre demonstrated excellent control against the nymphs through 20 days (Table 18). Dyfonate at 1 1b AI/acre exhibited 87\% control after 20 days. Dursban at $0.51 \mathrm{~b}$ A.I/acre and carbofuran and methomyl each at 1 1b AI/acre approached adequate control.

Experiment 4.- Baygon at $1.5 \mathrm{lb} \mathrm{AI} / \mathrm{acre}$ and methomyl at $2 \mathrm{lb} \mathrm{AI} / \mathrm{acre}$, both having systemic properties, gave excellent control of nymphs at the 13 day interval (Table 19). Dyfonate and Bayer 37289 each at 1 1b AI/acre also gave excellent contro1. Although not systemics, they have closely related chemical structures which seem to be effective in controlling the nymphs.

At the time of application, most of the nymphs in the field were in the last instar. Between the 6 day and 13 day intervals there was an extensive emergence of adults in the area. This explains the reduction in the number of spittiemasses per square foot in the check plots.

Table 20 indicates that Dyfonate, methomy1, Bayer 37289, and Baygon were superion in their ability to protect the grasses from damage by spittlebugs. Each had a mean rating of less than 1 which indicated that the grasses in those plots varied from no damage to some yellowing with 


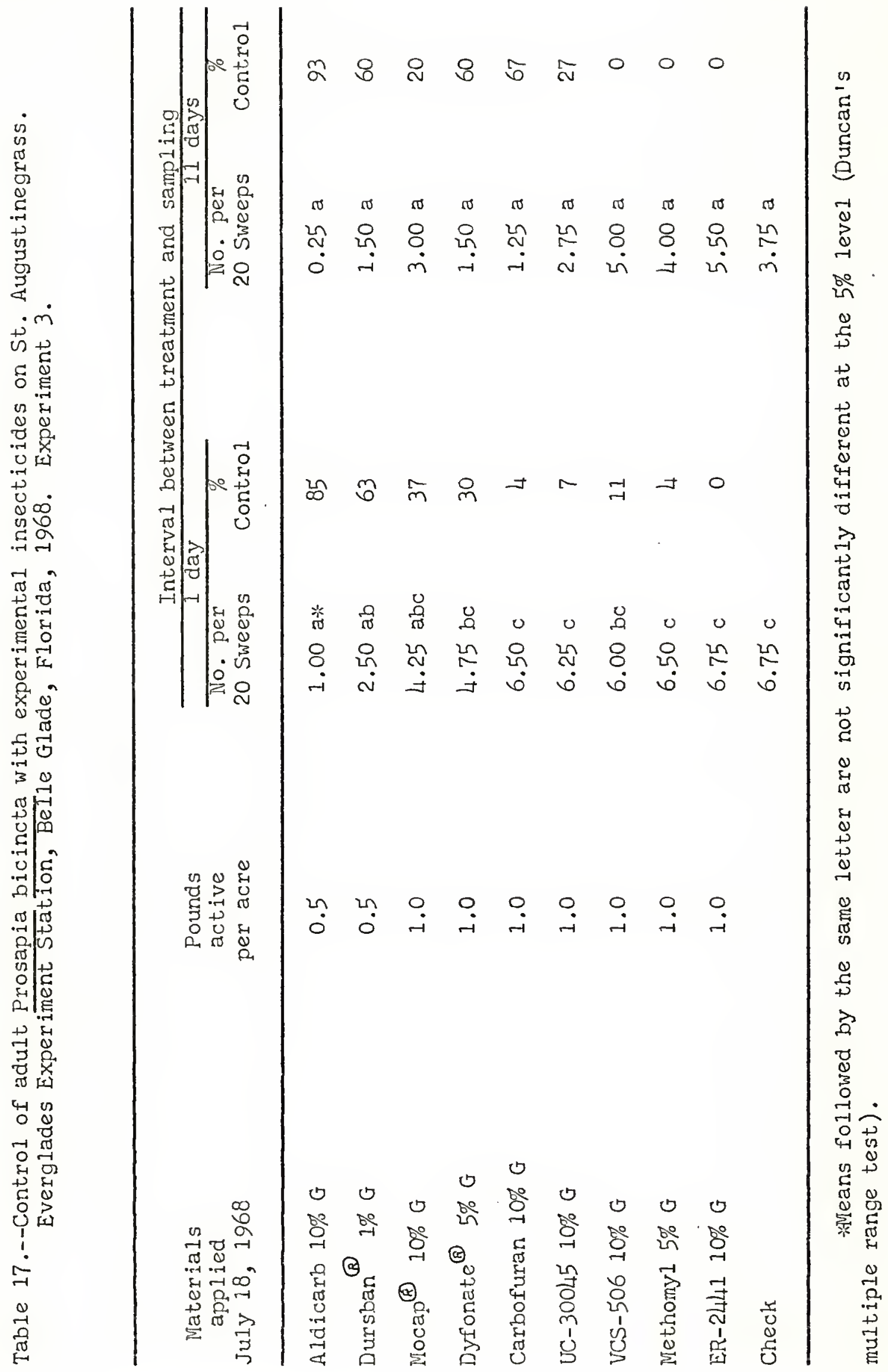




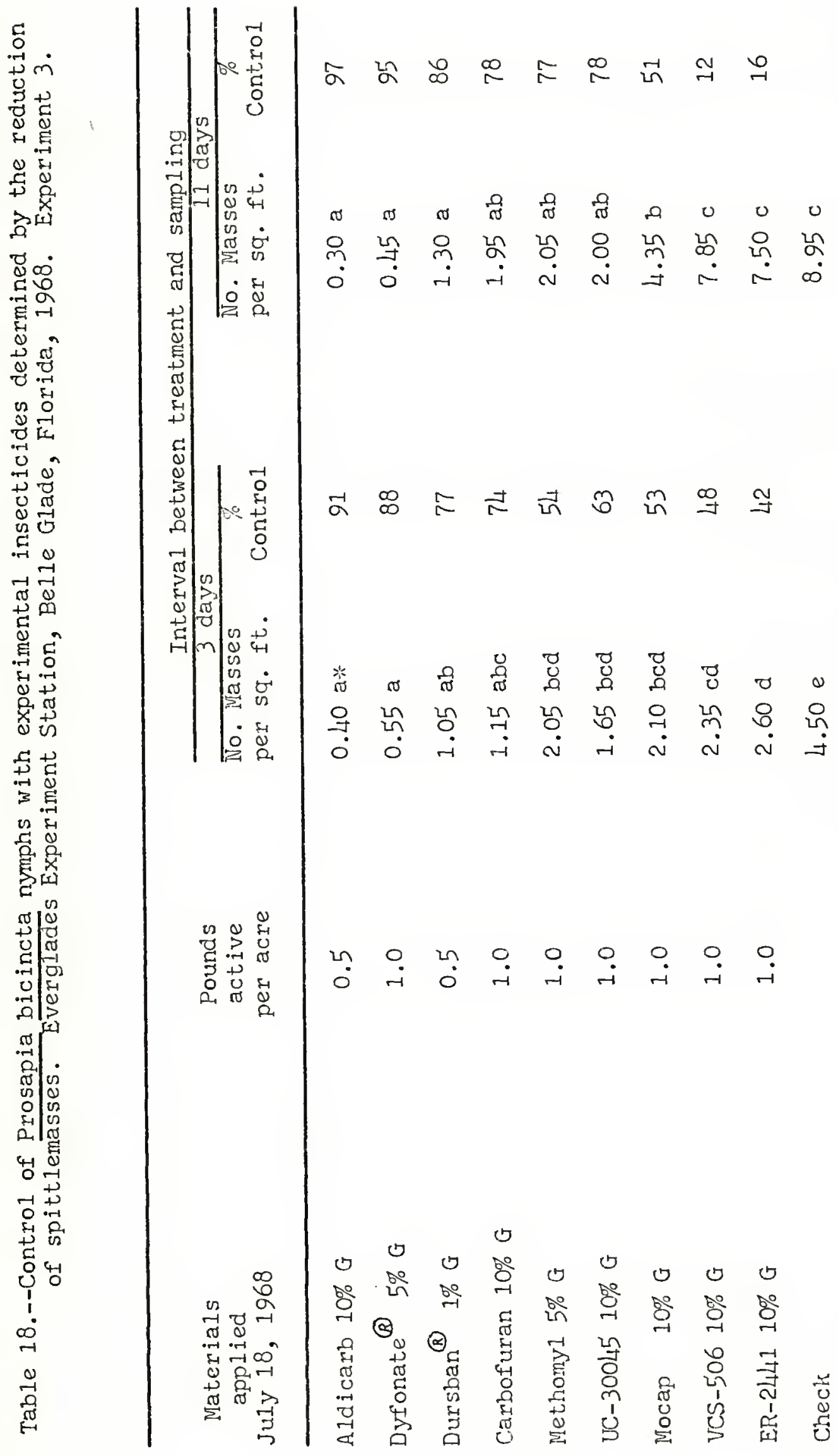




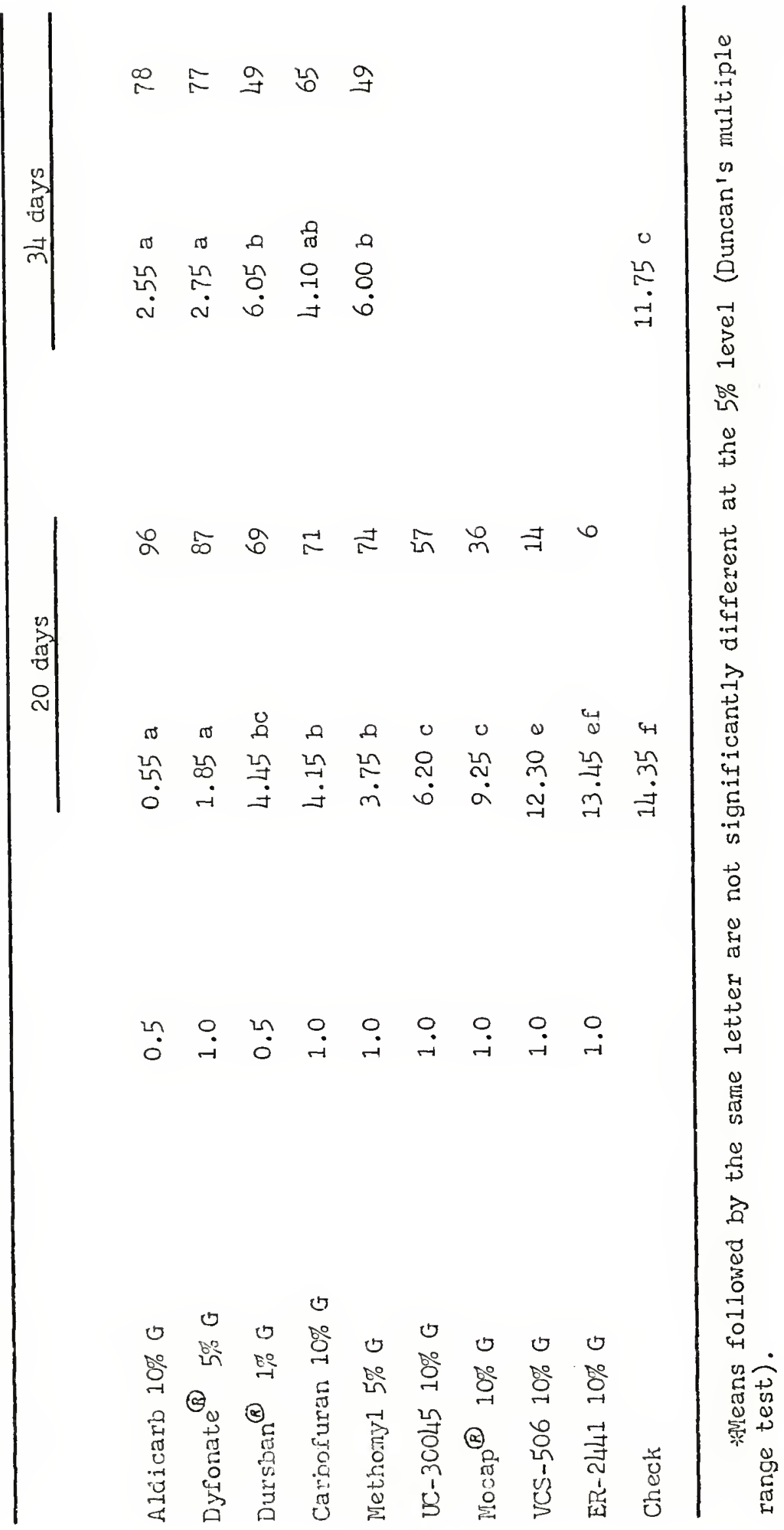




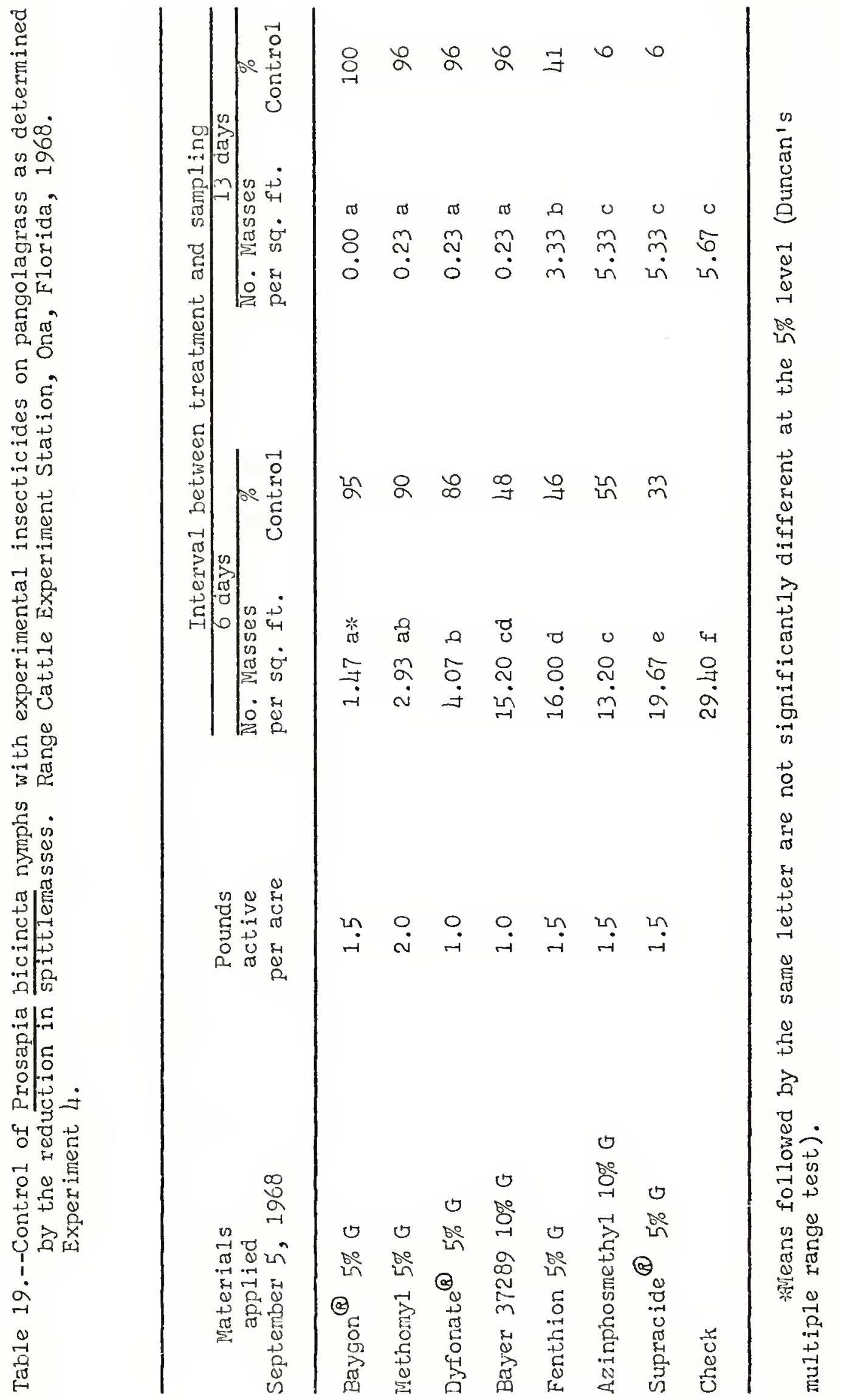


离|

空芒

을

帘

要

ह

出

च2 9

in

थ

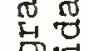

वै

至

$+3$

号

मू

मू

4

事索

o) थ

$\rightarrow+0$

$\bigcup_{-1}^{0}$

足

o 5

党

$\stackrel{4}{x}$

-1

ชิ

足出

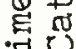

H

这

का ह

4

o

in

बत

$\sum_{1}^{0}$

$+\mathrm{U}$

o. $\rightarrow$

प्ष

!

$\dot{\mathrm{O}}$

$\stackrel{0}{\frac{1}{0}}$

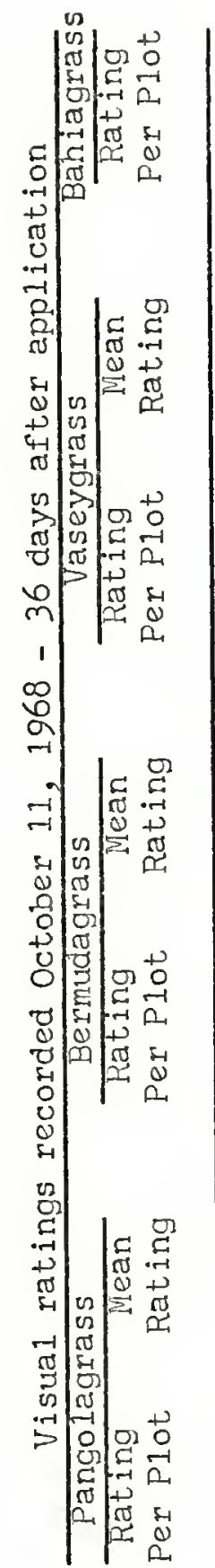

○

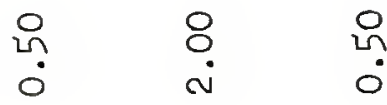

용

$\dot{0}$

$\stackrel{n}{r-1} \stackrel{m}{\sim}$

HनH N N M

$\begin{array}{llll}1 & 1 & 0 & 0\end{array}$

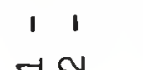

$-1+1$

$N+r$

Nmm man

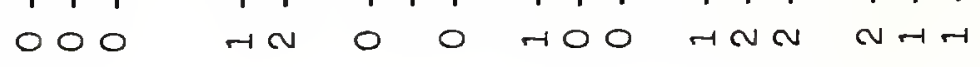

ㅇํㅇ

은

$\underset{i}{\stackrel{0}{i-i}}$

$\stackrel{r}{r}$

ㅇ
$\dot{m}$

$\stackrel{7}{\dddot{H}}$

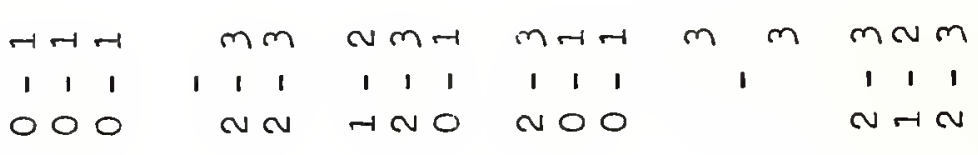

눙

$\stackrel{\mathfrak{M}}{\longleftarrow}$

$\stackrel{\circ}{\circ}$

$\stackrel{m}{\infty}$

잉

눈

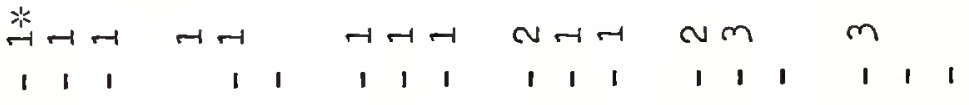

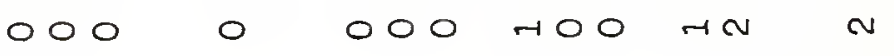

옹
+0
0
0
0
0
क्ष

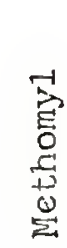

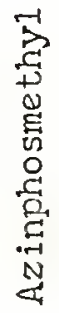

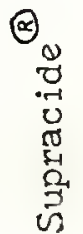




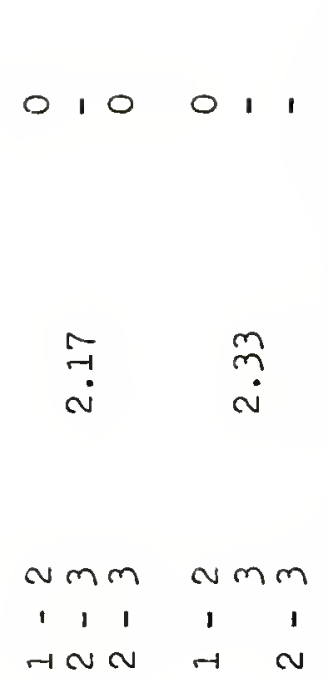


little browning. No phytotoxicity was noted in any of the treatments.

Experiment 5.--Aldicarb at $0.51 \mathrm{~b}$ AI/acre again proved to be the best material for controlling spittlebug nymphs (Table 21). Phorate, carbofuran, and Dasanit each at 1 1b AI/acre gave 97\%, 97\%, and 94\% control, respectively, at the 13 day interval. The systemics, dimethoate and disulfoton, were ineffective at the rates used.

As might be expected Table 22 indicates that phorate, aldicarb, carbofuran, Dasanit, and parathion best protected the grasses against spittlebug damage. No phytotoxicity was recorded. Summary on chemical contro1.---It might be advantageous to review the habits of the two-lined spittlebug as related to possible control measures. Adults emerge throughout the growing season with peaks in June and September. They probably live about 3 weeks in the field. They are rather inactive during the hottest part of the day and tend to stay in the same habitat as the nymphs; i.e., next to the soil with the top growth of the grass protecting them. The adults, especially the males, tend to be much more active on cloudy days and at night.

Although they are difficult to reach directly with a chemical during the day, they should come in contact with a residual on the grass or soil during their night time movements. Experiments have proven that sprayed materials will control the adults. If possible, sprays should be applied at the beginning of a 3-4 day dry period. This will allow 2-3 nights for the adults to come in contact with the insecticide deposited on the grass. Granular formulations of insecticides may be as effective as sprays when they are applied over an extersive area. The granules would fall down through the grass and rest where the adults spend their daylight hours. As granules, the insecticide is kept down under the grazing level of the 


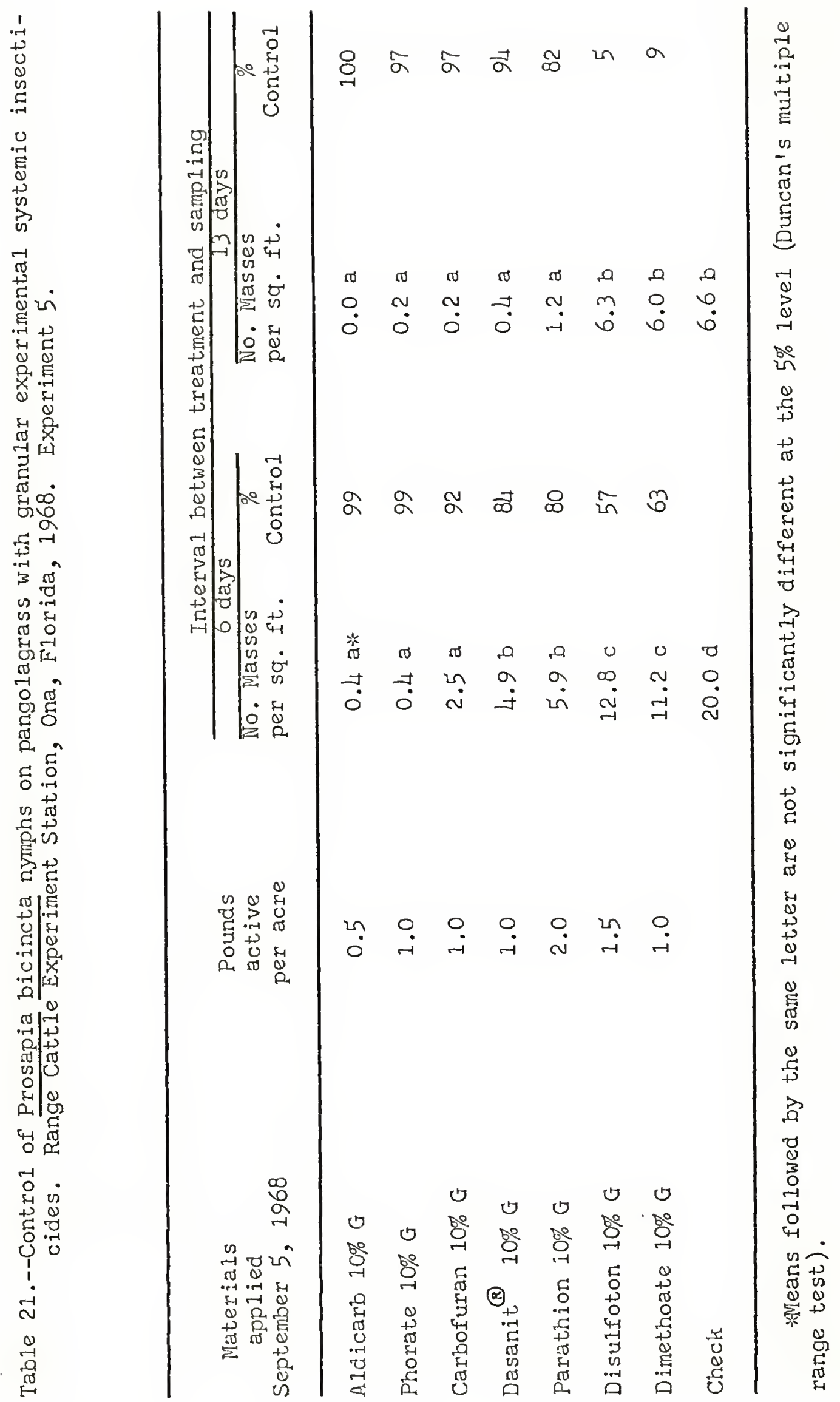




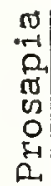

$\vec{\Omega}$

崩

宽

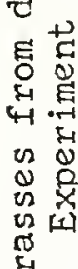

皆.

घूด

in

O

$+7$

मे

मा त्र

क्ष

ข

-

ט

U.

i

点句

늠

品.

का

का

要

过

.

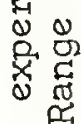

岁密

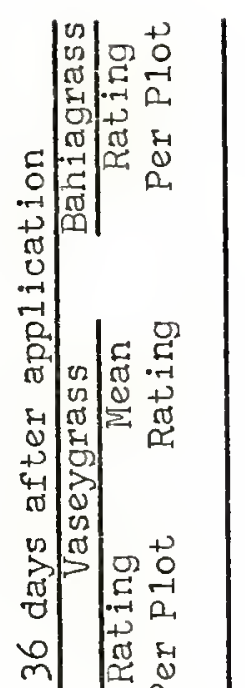

1101

11111000

1100

0100

$\infty$
$\infty$
0

ํํำ

$\stackrel{m}{r}$

$\stackrel{2}{0}$

$\stackrel{m}{r}$

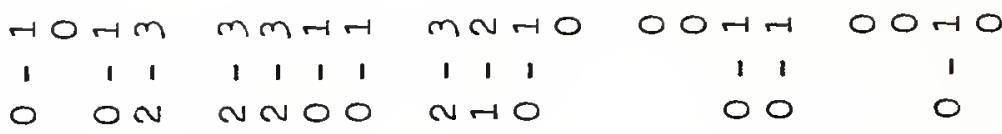

1

吕

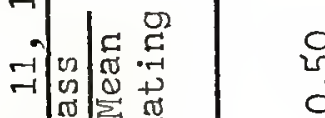

용

$\stackrel{m}{m}$

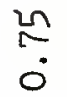

$\stackrel{m}{\sim}$

0

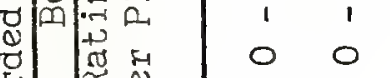

$\begin{array}{ccc}0 & 0 \\ 1 & 1 & 0 \\ -1 & 0 & 0\end{array}$

mmrm mao

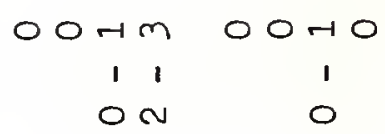

ठำ

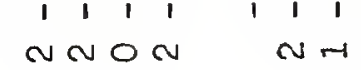

$\begin{array}{ll}8 & 8 \\ 0 & -1\end{array}$

$\stackrel{m}{m}$

$\stackrel{-1}{\circ}$

$\stackrel{m}{?}$

瓷 000

$$
\begin{aligned}
& \begin{array}{cccccc}
N & N & -1 & H & -1 & -1 \\
1 & 1 & 1 & 1 & 1 & 1
\end{array} \\
& \text { HroO } 00
\end{aligned}
$$

(2)

苾

$\sum_{\substack{\infty \\+\infty}}^{\pi}$

ب1

\&

प1

i

ำ

(

离

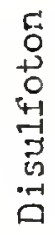

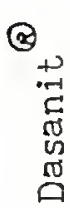

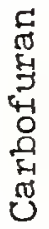

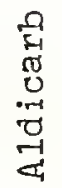


111100001110

$\begin{array}{lll}0 & 8 & 8 \\ \text { ํ } & \text { - } & \text { ஸे }\end{array}$

$m m n-m-1-1 m m m$

$\begin{array}{lllllllll}1 & 1 & 1 & 1 & 1 & 1 & 1\end{array}$

nNoo noojo nNmo

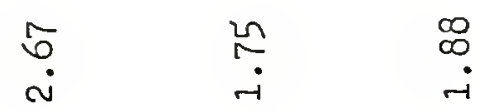

mmm morrm momr

$\begin{array}{llllllllll}1 & 1 & 1 & 1 & 1 & 1 & 1 & 1 & 1 & 1\end{array}$

N N NHON NH

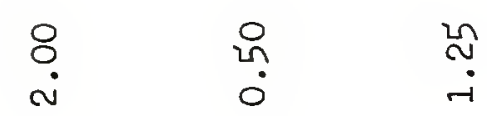

MN

$\begin{array}{llllllllllll}1 & 1 & 1 & 1 & 1 & 1 & 1 & 1 & 1 & 1 & 1 & 1\end{array}$

NH 0000 HAHO

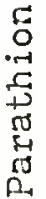

皆
유류

䨔 3 o 茴 $\rightarrow$ $\stackrel{0}{-1}$ 苟 $00-1$

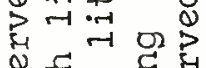
की टा है

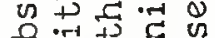

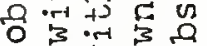
(2) 3 \& 음묘

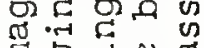
密资嵒

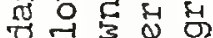
- न广 0

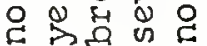
" $\|$ " $\|$ " $0 r \sim m 1$ 
livestock and should reduce the residue hazard on grass unless a systemic is used.

of the materials with clearance for use on pastures, carbaryl has given the best contro1. This insecticide sprayed at $1.51 \mathrm{~b} \mathrm{AI/acre} \mathrm{over}$ a large enough area should control the adults. If the pasture is held for a long period, it may be necessary to repeat the treatment. Any short residual spray treatments which control the adults and not the nymphs will provide only temporary control for new adults will be continually emerging.

Nymphs tend to wander about after hatching in search of a feeding site. They should be susceptible to residual insecticides at the soil surface. The nymphs feed next to the ground on runners, roots, and stems where they are protected by their spittlemass, debris, and the canopy of grass. Under these conditions it is difficult to reach the nymph with an insecticide. The nymphal stage lasts about 50 days under optimum conditions.

Spray treatments, even with the systemic, dimethoate, did not give good nymphal control. A systemic sprayed on the foliage would have to be translocated down to be effective. In contrast, granular systemics have proved superior in controlling the nymphs. On granules the systemic is placed near the roots where the plant absorbs and translocates it upward past the site of the feeding nympin.

Systemics tend to even out poor distribution in application, extend the residual effect in that deposits are not washed off as are those of conventional sprays and dusts, and, because of their selectiveness against sucking insects, they can control plant pests without eliminating beneficial insects. Unfortunately there are no systemics presently cieared for use on pastures. 
Control measures will vary according to the circumstances. When the infestation appears to be localized, a spot treatment may be all that is necessary. For other infestations, a thorough appljcation over a large area may be needed. 
ECONOMIC IMPORTANCE, CULTURAL AND

CHEMICAL CONTROL OF Prosapia plagiata

ON KIKUYUGRASS IN COSTA RICA

About 20 years ago (1947) entomologists at the Ministerio de Agricultura of Costa Rica first received reports of kikuyugrass (Pennisetum clandestinum Hochst.) pastures turning yellow, then brown and dying. Upon investigation, this damage was attributed to high populations of the spittlebug, Prosapia plagiata (Distant). This species apparently injures grass in the same manner reported for $\underline{P}$. bicincta in the southeastern United States. Phytotoxic salivary substances injected into the plant by adult spittlebugs during feeding cause progressive symptoms of injury depending upon the degree of infestation and length of feeding time. In a typical year, damage first appears in June and by August and September entire pastures are yellow and brown from spittlebug injury.

A review of the literature revealed only a few papers on the species, mostly concerning the taxonomic position. Washbon (91) presented some information on the biology, ecology and control of $\underline{P}$. plagiata. Most of his work was done in cooperation with this writer and Ovidio Vargas P. of the Departmento de Entomologia, Ministerio de Agricultura y Ganaderia, San Jose, Costa Rica.

\section{Synonymy}

Sphenorhina plagiata Distant 1878. (14)

Tomaspis plagiata Fowler 1897. (21)

Tomaspis distanti Lallemand 1912. (37) 
Sphenorhina biformis Lallemand 1927. (38)

Prosapia plagiata (Distant) Fennah 1953. (17)

\section{Description}

$\underline{P}$. plagiata can be differentiated from other related forms according to the following family, generic, and specific characters. The beak arises from the hind part of the head. The tarsi are 3-segmented. The antennae are very short, bristle-like, and inserted on the front of the head between the eyes. Two ocelli are present on the vertex. The hind tibia bear two stout spines and a crown of short spines around the apex. The anterior margin of the pronotum is straight. The third joints of the antennae are slightly conical, with the shorter arista placed distinctly basa of the long arista. The postclypeus is abruptly rectangulate in profile. The pronotum is dark and transversed by a broad paie band. The tegnina is usually a sordid yellowish brown and always devoid of markings (Figure 12).

There are two distinct color forms of $\underline{\mathrm{P}}$. plagiata, a brown and a red. The ground color of the body, abdomen, and the pronotum is very dark fuscous or fuscous-piceous in both. But the tegmina, transverse pronotal band, postclypeus, and parts of the legs of the brown form are a sordid yeilowish-brown. In the red form, all parts of the insect corresponding to the yellowish-brown color of the brown form are rufus to rosy brown.

The red form is not rare but is not nearly as prevalent as the brown form. It has been collected occasionally in many of the localities that the species is found but appears in highest numbers in one particular area northeast of San Isidro de Coronado. Both sexes can be found whereever the red form occurs. Also many individuals showing intermediate color shades can be found. On one occasion a red form female was observed 
Ilating with a brown form male in the field. Although breeding tests have not been run in the $1 \mathrm{ab}$, it is presumed that all combinations of cross breeding take place readily.

The sexes are readily recognized in the field due to the length of the tegmina. In the male, it extends posteriorly distinctly farther than in the female (Figure 12).

\section{Influence of Feeding on Kikuyugrass}

The objective of this study was to determine what influence the feeding of different densities of adult $\underline{P}$. plagiata has on kikuyugrass. Materials and Methods

Kikuyugrass was grown in 8 inch pots in the greenhouse. There were 5 plants per pot. When the grass was firmly established, 20 pots were selected and the dead or unhealthy leaves removed.

Adult spittlebugs were confined on these plants in cylindrical screen cages covered at the top with cheesecloth. Insects were selected for the test from field collected spittlebugs maintained on caged kikuyugrass in the greerhouse.

The test involved 4 treatments and a check replicated 4 times. Treatments consisted of confining 0,5,10,20, and 40 adults per cage. These treatments were assigned the letters $A, D, C, D$, and E, respectively. Check plants were also caged. Spittlebugs of both sexes were used in a 1 to 1 ratio. Treatments were randomized to avoid bench-location effects. The insects were allowed to continue feeding for two weeks. During the experimental period the pots were checked daily and visual observations were recorded. Adults were added daily if needed to keep the population at the desired leve1.

At the termination of the experiment, the plants were cut 1 inch 
Figure 12.--Male and female Prosapia plagiata. The tegmina of the male is distinctly longer. 
above the soil. The plant material from each population density was weighed to determine the green weight and then removed to the laboratory for analysis.

Results

On a wet basis, greater infestations produced consistent decreases in the percent of moisture (Table 23). However, on an oven dried basis, no significant differences were obtained in the percentages of proteins, ether extract, crude fiber, nitrogen-free-extract, and ash.

No visible differences were detected between treatment $B$ and the control throughout the experiment. After 5 days exposure, treatments $D$ and $\mathrm{E}$ showed some yellowing, particularly E. Following 7 days exposure, infestations of 40 spittlebugs produced wilting of the grass while early signs of wilting appeared in $D$. The kikuyugrass in treatment $C$ showed little if any yellowing.

After 9 days, the grass on which 40 adults were confined showed severe wilt but not death. Treatment $D$ showed slight wilt and now yellowing was present in $C$. Three days later, pots on which 40 adults were caged had grass which now had turned brown in color. This grass was considered completely top killed by spittlebug attack.

Discussion

Evidently kikuyrugrass is somewhat tolerant of spittlebug feeding. Exposures of one adult per stem (treatment B) for a two week period were insufficient to cause typical spittlebug injury symptoms. Thus only extremely high populations are economically important. This suggests that the virtual elimination of the insect fran the field is not necessary for control.

Originally, it was thought that spittlebug feeding would lower the 


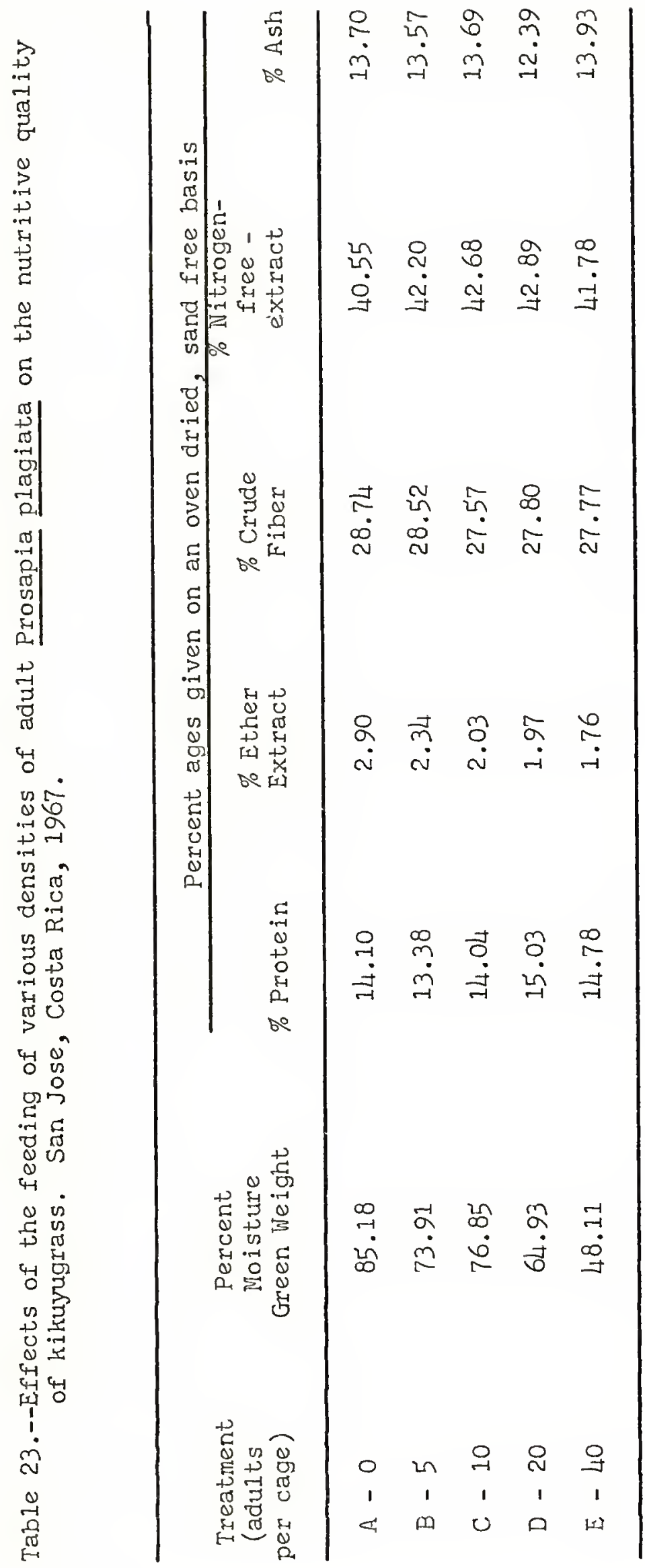


protein content of the grass. Analysis did not prove this. Perhaps the grass did not have time to lose protein because the heaviest infestation produced death in 12 days. Experiments should be designed to determine if light to medium infestations of spittlebugs over longer periods might reduce the protein content of the grass. Furthermore, from reviewing the literature it appears that meadow spittlebug feeding has different effects on different species of plants. This would indicate that additional data are needed concerning the influence of feeding by $\underline{P}$. plagiata on the nutritive value of other grasses.

Spittlebug attack greatly reduces the yield per acre by stunting the grass and causing it to dry in the field before it attains full growth. In addition, field observations showed that cows preferred normal grass over grass injured by spittlebugs. The grass of treatment $E$ has the same basic nutritional composition as properly aried forage (hay); however, hay is desirable because it is palatable, whereas spittlebug damaged grass is not.

Although the nutritive quality of the grass was not affected in this experiment, the percent moisture decreased as spittlebug injury increased. This loss of water may cause the grass to be unpalatable, or, perhaps the phytotoxic salivary substances which the spittlebug injects into the plant are directly or indirectly responsible for an "off-flavor" which contributes to the unpalatability.

Acknowledgment.--The authors wish to thank Dr. Hernan Fonseca, Facultad de Agronomia, Universidad de Costa Rica for conducting the laboratory analysis.

\section{Economic Importance}

The acreage of kikuyugrass is quite extensive in Costa Rica. It was introduced in 1926-28 and is the most important grass at the higher ele- 
vations. It establishes easily, grows very fast, and is not crowded out by weeds and other grasses. Present1y, there are about 143,000 acres in kikuyugrass.

After introduction, the established range of kikuyugrass was from about $1700 \mathrm{~m}$ to $2500 \mathrm{~m}$ elevation. This range has now been increased from $1200 \mathrm{~m}$ to $2700 \mathrm{~m}$. Below this range, kikuyugrass is damaged by the excessive heat, and above, it is extremely slow growing.

Although $\mathrm{P}$. plagiata can be found throughout the kikuyrgrass area, it presently is a pest only in parts of it (Figure 13).

\section{Contro1}

Cultura1 Control

The following control measures were recommended in 1966 by the Sub-

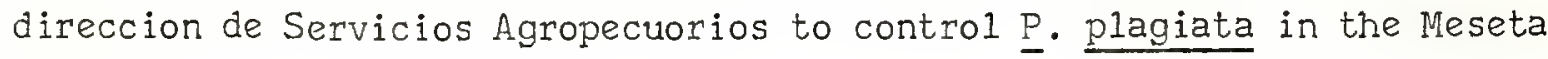
Central.

1. Make regular observations on the spittlebug population to detect any increase.

2. Continually strive to improve the pastures through better management practices.

3. Divide larger pastures into smaller areas to facilitate easier management.

4. Rototill pastures in March to control the nymphs and eggs.

5. Make regular applications of fertilizer to keep the grass in a vigorous state of growth.

6. Burn pastures in March to control eggs and nymphs. (This recommendation has since been withdrawn until further experiments can be conducted.)

Chemical Control

Relatively little information is avalable on chemical control of $\underline{F}$. plagiata. The Sub-direccion de Servicios Agropecuorios suggest methylparathion $1.5 \%$ or $2 \%$ EC or $4 \%$ malathion dust at $30-4016 \mathrm{AI} /$ manzana (=about 
1.75 acres) for control of the adult.

Washbon (91) found that phorate $10 \% \mathrm{G}$ at $2.24 \mathrm{~kg} /$ hectare $(=2 \mathrm{c}$ AI/acre) gave the best control of the nymphs. In an experiment conducted by the Departmento de Entomologia in 1965, nymphs were controlled by diazinon $5 \% \mathrm{G}$, disulfoton $5 \% \mathrm{G}$, and phorate $10 \% \mathrm{G}$ at 22.78 , 40 , and $20 \mathrm{~kg}$ actual/hectare respectively. The experiment reported here was designed to supply additional information pertaining to chemical control. Materials anc methods.--A randomized complete block design was laid out in an infested kikuyugrass pasture at the Finca Hollanda belonging to Senor Alberto Pacheco. This farm is in San Jose Province northeast of San Isidro de Coronado at $1970 \mathrm{~m}$ elevation. The plots measured $50 \mathrm{~m}$ by $10 \mathrm{~m}$.

There were 5 treatments and an untreated check replicated 4 times (Table 24). The dusts were applied by a hand duster. The granules were applied by hand, and the wettable powder was applied by a knapsack sprayer. A11 applications were conducted on June 8, 1967.

The nymphal population was sampled 1 day before and 4, 8, 15, and 22 days after treatment. Because of the high infestation and the resulting difficulty in counting individual nymphs, only the spittlemasses were counted in each sample. Using a 6 in. metal square, all the spittlemasses in 10 randomly selected areas of each plot were counted. The actual population was considered higher than the samples indicated because many spittlemasses contained more than one nymph. The data are summarized in Table 24.

Discussion and conclusions.--Only phorate and diazinon were effective in reducing the nymphal populations. Even so, phorate gave only $89 \%$ control at the 15 day interval. Because of the daily rains, phorate was taken up 

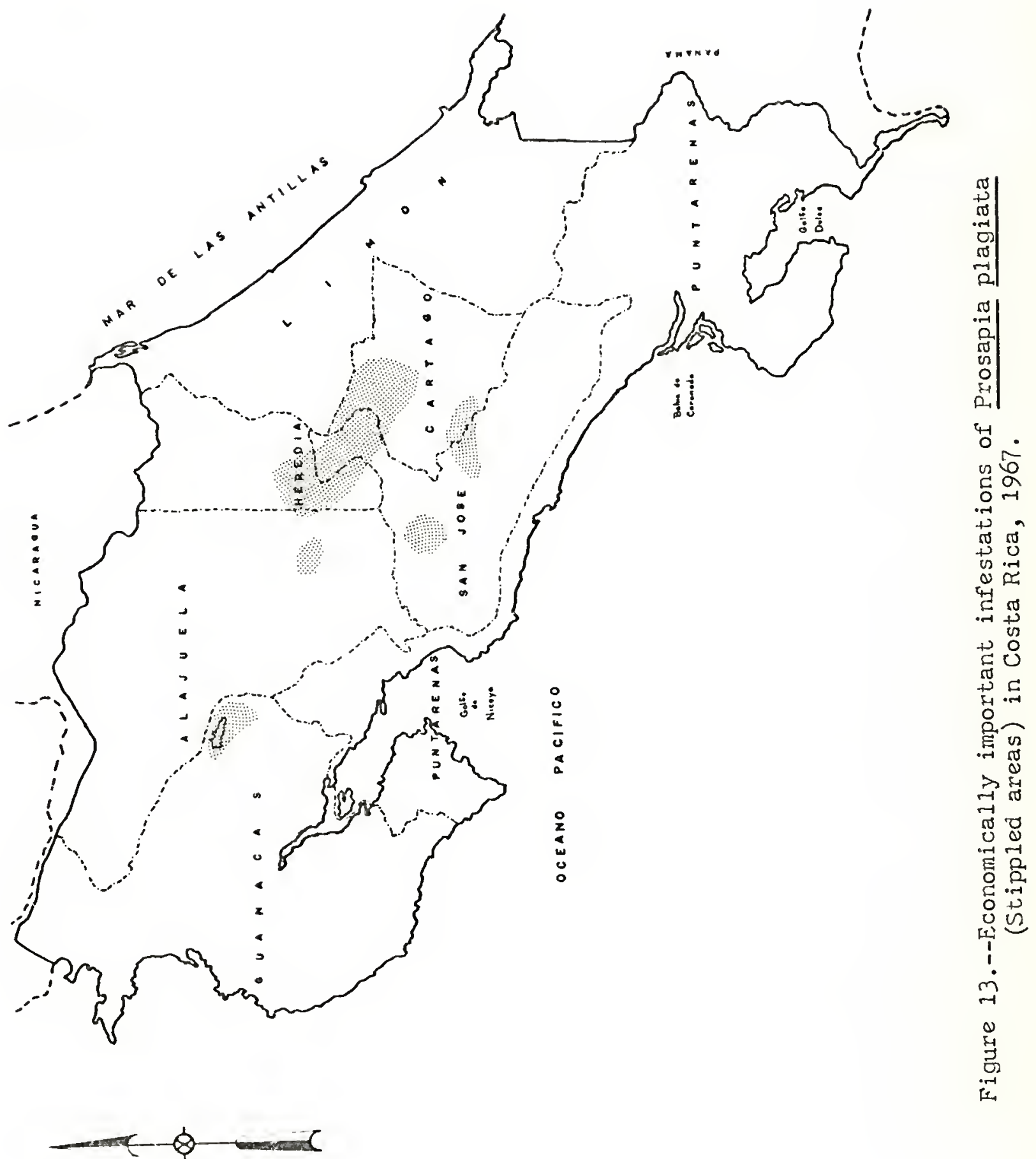


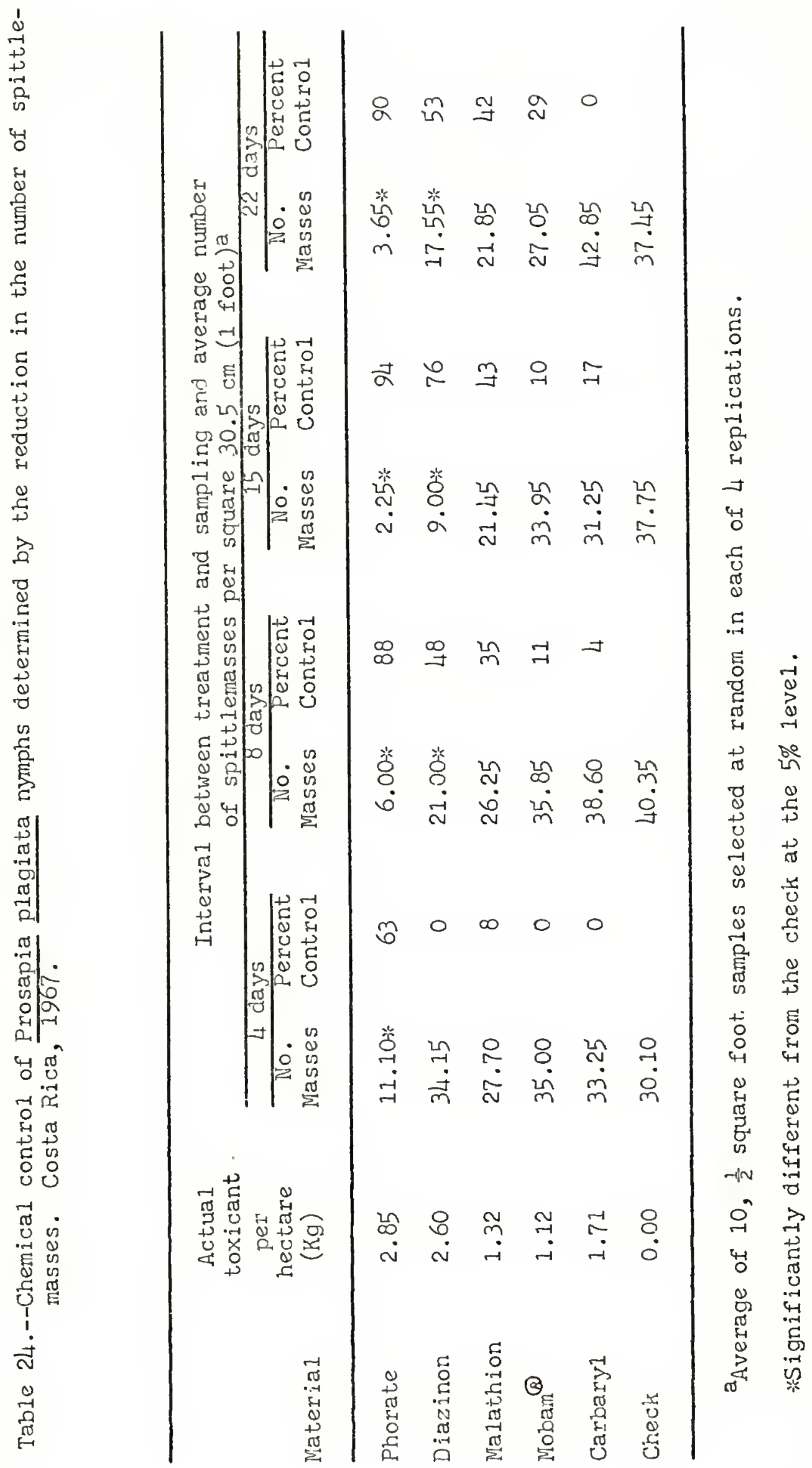


by the grass quickly and gave control. Diazinon was effective by the 8 day count and continued throughout the remainder of the experiment. It appeared that effectiveness of both phorate and diazinon was wearing off by the 22 day count.

In the opinion of the writer, problems in the chemical control of spittlebugs stem not from a need of insecticides to kill the insects but from the difficulty of getting the insecticide to the insect.

P. plagiata thrives in the moist protected environment of roots, stems, and debris provided by lush growth of kikuyugrass. It is the nature of both the nymphs and adults to stay down in the grass. The nymphs have the added protection of the spittlemass. Adverse weather also affects the application of insecticides. Populations are highest during the time of the year that daily rains commonly leave the grass continually moist. In this situation, dust formulations are practically useless. As the dust strikes the moist grass, it sticks there without penetrating downward. The next rain washes the dust through without it ever coming in contact with the insect. Sprays are not much better for some of the same reasons.

Insecticides applied as granular formulations probably are best suited to penetrate the grass mat. Systemic insecticides may prove to be the most effective in controlling the nymphs. If contact insecticides are to be used in spray formulations, care must be taken to apply when weather conditions are most favorable. Adults are most active on warm overcast days when it is not likely to rain. Bright sun or rain keeps them down under cover.

Although the plots were not measured for yield at the end of the experiment, it was interesting to note that the grass treated with phorate 
was taller and growing more vigorously than in any of the other plots. Besides having insecticidal properties, phorate appears to be effective in stimulating the growth of the grass. 


\section{SUMMIARY}

Relatively little information is available in the literature on the biology and control of the two-lined spittlebug, Prosapia bicincta, in Florida. Research was conducted from September, 1966, to June, 1969, in 3 locations in Florida. Experiments were conducted at the Everglades Experiment Station at Belle Glade on St. Augustinegrass, the Range Cattle Experiment Station at Ona on fangolagrass, and the Main Agricultural Experiment Station at Gainesvilie. In addition, 6 weeks were spent in 1967 studying a similar pest species of spittlebug, $\underline{P}$. plagiata, which attacks pasture grasses at high elevations in Costa Rica.

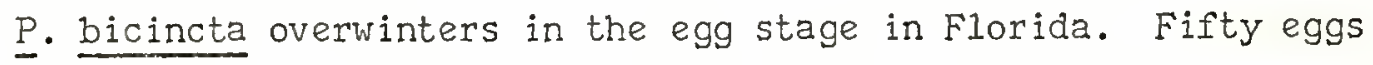
averaged $1.02 \mathrm{~mm}$ in length and $0.35 \mathrm{~mm}$ in width. Eggs are deposited in the moist 1 itter and debris at the base of grasses. Eggs held at $22.4^{\circ}$ $24.4^{\circ} \mathrm{C}$ on moist filter paper hatched in an average of 19 days. Eggs are sensitive to dry conditions and will not hatch unless moisture conditions are adequate.

Newly hatched nymphs are also very susceptible to desiccation. After feeding begins, they create spittlemasses and are then protected from desiccation. Nymphs are not confined to one site but move about, especially after molting. Nymphs feed on the stems and runners of grasses near the soil surface. Nymphs were recorded on 40 plants in Florida, predominantly grasses. There were 5 nymphal instars and the nymphal period averaged 50 days. 
Transformation to the adult takes place within the spittlemass formed at the last feeding site of the $5^{\text {th }}$ instar nymph. Caged virgin females, 2-6 days old, produced an easily detectable perfume-1ike odor. Females mate both before and after oviposition begins. Eggs are deposited in the field throughout the growing season. Caged females began ovipositing when 7 days old and averaged 50.3 eggs.

No parasites or predators were recorded for the eggs or nymphs. Four predators, 2 mites, and a parasitic fungus were recorded on the adults. The parasitic fungus, Entomophthora grylli,great1y reduced the adult population at the Range Cattle Station in September, 1968. It appears to be effective in natural outbreaks but too dependent upon optimum temperature and moisture conditions to be practical as a biological control measure.

Under greenhouse conditions the life cycle was about 76 days from egg to egg. Most of the overwintering eggs hatch from late March to late April in the field. The $1^{\text {st }}$ generation adults are then abundant in June. The adult population peaks again in early August to early September and this generation deposits overwintering eggs.

There were 2 peaks in light trap catches at Gainesville, one in June and another in August to early September. Light trap catches averaged 7799\% males. Seasonal peaks in the female population appeared to be identical with that of the males. Traps placed with the lamp centered 48 in. above the ground caught more spittlebugs than those at $120 \mathrm{in}$. and 24 in. high traps did better than those $48 \mathrm{in.} \mathrm{high.} \mathrm{Blacklight} \mathrm{BL} \mathrm{lamps} \mathrm{at-}$ tracted more spittlebugs than other colors. There was only 1 peak of activity per night for both sexes. About $85 \%$ of the nightly spittlebug catch was taken by midnight. Precipitation during this period of activity 
greatly reduced light trap catches.

Adults rather than nymph, apparently cause the visible damage to grasses. Single adults caged on individual stems of pangolagrass killed the blades in 1-3 days and the stems in 3-4 days. Spittlebug damaged pangolagrass and bermudagrass contained less moisture and up to $45 \%$ less protein than undamaged grasses.

In general, any cultural control practice which reduces the heavy top growth of grass, reduces the litter and debris at the soil surface, or opens the stand for drying will inhibit a high population of spittlebugs. Spring burning is beneficial for bermudagrass but injures pangolagrass. Mowing and heavy grazing in mid and late summer prevents the heavy growth of grass and reduces spittlebug problems. Harvesting for hay or silage in late summer should prevent spittlebug damage and still provide winter pasture. Renovation, chopping, or discing in the spring disturbs the sod, reduces the surface litter and debris, and inhibits spittlebug build-up in late summer. Of 19 grasses compared to pangolagrass in a field trial, 2 Brachiaria and 3 Hemarthria introductions showed little or no spittlebug injury.

Nine chemical control experiments were conducted against the twolined spittlebug.

Sprays were more effective against adults than granular formulations. Azinphosmethyl in 1967, and in 1968, dimethoate, endosulfan, diazinon, and parathion each sprayed at $0.5 \mathrm{lb}$ AI/acre controlled the adults. Sprays of Dursban and GS-13005 at 2 1b AI/acre and carbaryl at $1.51 \mathrm{~b}$ AI/acre also controlled the aduits. Granular applications of aldicarb, Dursban, and phorate at 2, 0.2 , and $1 \mathrm{lb}$ AI/acre, respectively, initially controlied the adults. Prany granular materials will probably control the 
adults but valid data were difficult to obtain because of the small plots and mobility of the adults.

Granular systemic insecticides provided the best control against nymphs. Aldicarb, Bayer 37289, carbofuran, Mobam at 2 1b AI/acre and Dursban at $0.21 \mathrm{~b}$ AI/acre gave above $85 \%$ control of the nymphs in one experiment. Phorate at $1 \mathrm{lb}$ AI/acre yielded excellent control of the nymphs through 27 days following application on St. Augustinegrass. Aldicarb at $0.51 \mathrm{~b}$ AI/acre and Dyfonate at $1 \mathrm{~b} \mathrm{AI/acre} \mathrm{gave} 96 \%$ and $87 \%$ control 20 days after application. On pangolagrass in 1968, Dyfonate, Bayer 37289, phorate, carbofuran, and Dasanit each at 1 1b AI/acre, Baygon at $1.51 \mathrm{~b}$ AI/acre, methomyl at $21 \mathrm{~b}$ AI/acre, and aldicarb at 0.5 1b AI/acre al1 gave more than $85 \%$ control of the nymphs.

Prosapia plagiata is primarily a pest on kikuyugrass in Costa Rica. This species apparent1y injures grass in the same manner as $\underline{P}$. bicincta; i.e., phytotoxic salivary substances injected into the plant by adult spittlebugs during feeding cause progressive symptoms of injury. There are about 143,000 acres in kikuyugrass in Costa Rica within the elevations of $1200 \mathrm{~m}$ to $2700 \mathrm{~m}$. Although $\mathrm{P}$. plagiata can be found throughout this area, it presently is a pest only in parts of it. There are 2 distinct color forms of $\mathrm{P}$. plagiata, a more common brown form and a red form. The sexes are easily recognized in the field due to the longer tegmina of the male.

In a greenhouse experiment, spittlebug feeding greatly reduced the moisture content of kikuyugrass but the percent protein was not significantly rediced.

Cultural control measures are used more extensively than chemical control. Phorate $10 \% \mathrm{G}$ at $2.85 \mathrm{~kg} \mathrm{AI} /$ hectare controlled the nymphs through 22 days after application. 


\section{LITERATURE CITED}

1. Ball, E. D. 1899. A review of the Cercopidae of North America, North of Mexico. Iowa Acad. Sci. Proc. 6: 204-226.

2. 1928. Notes on the Cercopidae of America North of Mexico (Homoptera). Entomo1. News 39: 47-49.

3. Beck, E.W. 1963. Observations on the biology and cultural-insecticidal control of Prosapia bicincta, a spittlebug, on Coastal bermudagrass. J. Econ. Entomo1. 56:747-752.

4. Berg, C. 1879. Hemiptera Homoptera Latr. Hemiptera Argentina enumeravit speciesque novas descripsit 1879: 1-276.

5. Boring, A. M. 1923. The varieties of Monecphora bicincta from the point of view of a cytologist. Psyche 30:89-92.

6. Bromley, S. W. 1914. Asilids and their prey. Psyche 21: 192-198.

7. Byers, R. A. 1965. Biology and control of a spittlebug, Prosapia bicincta (Say), on Coastal bermudagrass. Univ. Georgia Agr. Exp. Sta. Tech. Bul1. N. S. 42.26 p.

8. Eyers, R. A. and C. M. Taliaferro. 1967. Effects of age on the ability of the adult two-lined spittlebug, Prosapia bicincta, to produce phytotoxemia of Coastal bermudagrass. J. Econ. Entomo1. 60: 1760-1751.

9. Byers, R. A. and H. D. We11s. 1966. Phytotoxemia of Coastal bermudagrass caused by the two-linea spittlebug, Prosapia bicincta (Homoptera: Cercopidae). Ann. Entomo1. Soc. Amer. 59: 1067-1071.

10. Byers, R. A., D.W. Woodham, and M. C. Bowman. 1965. Residues on Coastal bermudagrass, trash, and soil treated with granular endosulfan. J. Econ. Entomol. 58: 160-161.

11. Cardin, P. 1917. Report of an inspection trip to the pastures of the ranch "La Horqueta" Camaguey, in order to investigate a plague in the fields of Parana. Cuba Comision Sanid. Veg. Bol. 1: 38-43.

12. Cockere11, T. D. A. 1908. Fossil Cercopidae (Homoptera). Wis. Natur. Hist. Soc. Bul1. 6: 35-38. 
13. Crampton, G. C. 1922. Evidences of relationship indicated by the venation of the fore wings of certain insects, with especial reference to the Hemiptera-Homoptera. Psyche 29: 23-41.

14. Distant, W. L. 1878. Notes on some Hemiptera-Homoptera with descriptions of new species. Trans. Entomol. Soc. Lond. 1878: 173-179.

15. Doering, K. C. 1930a. Synopsis of the family Cercopidae (Homoptera) in North America. J. Kans. Entomol. Soc. 3: 53-64.

16. 1930b. Synopsis of the family Cercopidae (Homoptera) in ivorth America. J. Kans. Entomol. Soc. 3: 81-108.

17. Fennah, R. G. 1963. Revisionary notes on neotropical Monecphorine Cercopoidea (Homoptera). Ann. and Mag. Natur. Hist. (12)6: 337-360.

18. Fewkes, D.W. 1960. Number of nymphal instars of the sugarcane froghopper, Aeneclamia varia saccharina Dist. Nature 188(4745): 167168.

19. 1963. The effect of exposure to dry conditions on the eggs of Aeneolania varia saccharina (Homoptera: Cercopidae). Ann. Entomo1. Soc. Amer. 56: 719-720.

20. Fitch, A. 1856. Third report on noxious and other insects of the state of New York. N. Y. State Agr. Soc. Trans. 16: 315-490.

21. Fowler, W. W. 1897. Order Rhynchota. Suborder Hemiptera-Homoptera. Biologia Centrali Americana 2: 169-184.

22. Froeschner, R. C. 1946. The Cercopidae or spittlebugs of Missouri. J. Kans. Entomo1. Soc. 19: 30-35.

23. Frost, S. W. 1962. Winter insect light-trapping at the Archbold Biological Station, Florida. Fla. Entomo1. 45: 175-190.

24. 1963. Winter insect 1ight-trapping at the Archbold Biological Station, Florida. Fla. Entomo1. 46: 23-43.

25. Genung, W. G. 1955. Control of insects and related pests of pastures. Annu. Rep. Fla. Agr. Exp. Sta. 1955: 235-236.

26. 1956. Insects reduce quantity and quality of pasture grasses. Sunshine State Agr. Res. Rep. 1(2): 8-9.

27. Genung, W. G. and R. J. Allen, Jr. 1962. Survey of insects associated with agronomic introductions. Proc. Soil and Crop Sci. Soc. Fia. 22: 153-159.

28. Genung, W. G. and J. R. Orsenigo. 1965. Insect infestation in relation to subsequent weed invasion of improved pastures. Fla. Entomo1. 48: 221-226. 
29. Glick, P.A. 1939. The distribution of insects, spiders, and mites in the air. U. S. Dept. Agr. Tech. Bull. 673: $150 \mathrm{p}$.

30. Hanna, M. and T. E. Moore. 1966. The spittlebugs of Michigan (Homoptera: Cercopidae). Papers Mich. Acad. Sci., Arts, Letters. 51: 39-73.

31. Hodges, E. M., G. B. Killinger, J. E. McCaleb, O. C. Ruelke, R. J. Allen, Jr., S. C. Schank, and A. E. Kretschmer, Jr. 1967. Pangolagrass. Univ. Fla. Agr. Exp. Sta. Bul1. 718. 31 p.

32. Hollingsworth, J.P., J. G. Hartsock, and J. M. Stanley. 1963. Electric insect traps for survey purposes. USDA, Agr. Res. Ser. APS 42-3-1. $23 \mathrm{p}$.

33. Holloway, T. E. and U. C. Loftin. 1919. Insects attacking sugar cane in the Unitea States. J. Econ. Entomol. 12: $448-450$.

34. Hume, H. H. 1953. Hollies. The Macmillan Co. New York. 242 p.

35. Ingram, J.W., E. K. Bynum, R. Mathes, W. E. Haley, and I. J. Charpentier. 1951. Pests of sugarcane and their control. U.S. Dep. Agr. Circ. 878. 38 p.

36. King, E.W., C.D. Pless, and J. K. Reed. 1965. An automatic samplechanging device for light-trap collecting. J. Econ. Entomo1. 58: $170-172$.

37. La11emand, V. 1912. Genera Insectorum. Homoptera: Cercopidae. 1-167.

38. 1927. Descriptions of some Cercopidae in the British Museum. Trans Entomo1. Soc. Loná. 75: 99-118.

39. Maerz, A. and M. R. Paul. 1930. Dictionary of color. McGraw-Hill Booki Co., Inc. New York. 207 p.

40. McCaleb, J. E. and E. M. Hodges. 1963. Control of insects and related pests of pastures. Annu. Rep. Fla. Agr. Exp. Sta. 1963: 327.

41. 1964. Control of insects and related pests of pastures. Annu. Rep. Fla. Agr. Exp. Sta. 1964: 344.

42. Mead, F.W. 1962. A spittlebug, Prosapia bicincta (Say) (Homoptera: Cercopidae). Fla. Dep. Agr. Div. Plant Industry Entomol. Circ. No. $7.1 \mathrm{p}$.

43. Metcalf, Z.P. 1917. The wing venation of the Cercopidae. Ann. Entomo1. Soc. Amer. 10: 27-32.

44. 1961. General catalogue of the Homoptera. Fascicle VII. Cercopoidea. Part 2. Cercopidae. North Carolina State College, Raleigh, N. C. 607 p. 
45. Metcalf, Z. P. and S. C. Bruner. 194/4. The Cercopiaae of Cuba. Elisha Mitchel1 Sci. Soc. J. 60: 109-128.

46. Moore, T.E. 1955. Important Illinois spittlebugs. I11. Natur. Hist. Surv. Indentification Notes 2. $7 \mathrm{p}$.

47. Morse, A. P. 1921. Monecphora bicincta (Say) in New England. Psyche 28: $27-28$.

48. Osborn, H. 1939. Meadow and pasture insects. The Educators' Press. Columbus, Ohio. 288 p.

49. Pass, B. C. and J. K. Reed. 1965. Biology and control of the spittlebug, Prosapia bicincta, in Coastal bermuda grass. J. Econ. Entomol. 58: 275-278.

50. Rhoades, W. C. and R. W. Murray. 1967. A synecological study of the imported fire ant eradication program. Univ. Fla. Agr. Exp. Sta. Bul1. 720. $42 \mathrm{p}$.

51. Say, T. 1830. Descriptions of new North American Hemipterous insects belonging to the first family of the section Homoptera of Latreille. Acad. Natur. Sci. Phila. J. 6: 299-314.

52. Signoret, V. 1853. Revue critique du groupe des Tettigonides et de la tribu des Cercopides. Rev. Mag. Zool. (2)5: 173-184.

53. Spooner, C.S. 1938. The phylogeny of the Hemiptera based on a study of the head capsule. I11. Univ. Bu11. 35: $102 \mathrm{p}$.

54. Sta1, C. 1864. Hemiptera mexicana enumeravit speciesque novas descripsit. Stettin Ent. Ztg. 25: 49-86.

55. Stearns, L. A. 1923. Family Cercopidae. In W. E. Britton's Guide to the insects of Connecticut. Part IV. The Hemiptera or sucking insects of Connecticut. Conn. State Geo1. and Natur. Hist. Surv. Bu11. 34: 206-238.

56. Steinhaus, E. A. 1949. Principles of insect pathology. McGrawHill Book Co., Inc. New York. $757 \mathrm{p}$.

57. Strayer, J.R. 1966. Pasture insect control. Univ. Fia. Agr. Ext. Ser. Circ. 292. 1 p.

58. Taliaferro, C. M., R. A. Byers, and G. W. Burton. 1967. Effects of spittlebug injury on root production and sod reserves of Coasta1 bermudagrass. Agron. J. 50: 530-532.

59. Tamburo, S. E. and F. G. Butcher. 1955. Biological studies of the Florida dusky wing skipper, and preliminary survey of ther insects on Barbados cherry. Fla. Entomo1. 38: 69.

60. Tombes, A. S. and B. C. Pass. 1961. Notes on the distribution and economic importance of Tomaspis bicincta (Say). Fla. Entomol. W4: 189. 
61. U.S.D.A. 1954. Coop. Econ. Insect Rep. 4(13): 259.

62. 1954. Coop. Econ. Insect Rep. 4(20): 400 .

63. 1ㄴ 1954. Coop. Econ. Insect Rep. 4(29): 655 .

64. 1954. Coop. Econ. Insect Rep. 4(34): 787.

65. - 1955. Coop. Econ. Insect Rep. 5(39): 922.

66. 1958. Coop. Econ. Insect Rep. 8(32): 704.

67. 1959. Coop. Econ. Insect Rep. 9(32): 737.

68. 1960. Coop. Econ. Insect Rep. 10(29): 659.

69. 1961. Coop. Econ. Insect Rep. 11(39): 910.

70. _ 1961. Coop. Econ. Insect Rep. 11(40): 929.

71. 1962. Coop. Econ. Insect Rep. 12(31): 869.

72. 1962. Coop. Econ. Insect Rep. 12(45): 1170.

73. 1963. Coop. Econ. Insect Rep. 13(28): 799.

74. 1964. Coop. Econ. Insect Rep. 14(20): 466.

75. 1 1964. Coop. Econ. Insect Rep. 14(21): 504.

76. 1964. Coop. Econ. Insect Rep. 14(24): 605.

77. ___ 1964. Coop. Econ. Insect Rep. 14(28): 754.

78. __ 1964. Coop. Econ. Insect Rep. 14(36): 1019.

79.

. 1965. Coop. Econ. Insect Rep. 15(25): 639.

80 .

1965. Coop. Econ. Insect Rep. 15(27): 711.

81.

1965. Coop. Econ. Insect Rep. 15(30): 833.

82.

1965. Coop. Econ. Insect Rep. 15(36): 1028.

83.

1965. Coop. Econ. Insect Rep. 15(38): 1092.

84.

1966. Coop. Econ. Insect Rep. 16(40): 957.

85.

- 1967. Coop. Econ. Insect Rep. 17(35): 808.

86.

- 1967. Coop. Econ. Insect Rep. 17(39): 890.

87.

. 1968. Coop. Econ. Insect Rep. 18(23): 487. 
88. - 1968. Coop. Econ. Insect Rep. 18(35): 835 .

89. University of Florida. 1965. The DARE (Developing Agricultural Resources Effectively) Report. Univ. of Fla. Institute of Food and Agricultural Sciences. Gainesville.

90. Walker, F. 1851. List of the specimens of Homopterous insects in the collection of the British Nuseum 3: 637-907.

91. Washbon, E. C. 1968. The biology and control of two species of spittlebugs, Genus Prosapia, (Homoptera: Cercopidae) in South Florida and Costa Rica. Unpublished Master's Thesis, Univ. of Fla.

92. Weaver, C. R. and D. R. King. 1954. Meadow spittlebug. Ohio Agr. Exp. Sta. Bul1. 741.99 p.

93. Wilson, M. C. and R. E. Shade. 1967. Relative attractiveness of various luminescent colors to the cereal leaf beetle and meadow spittlebug. J. Econ. Entomol. 60: 578-580.

94. Wray, D. L. and C. S. Brimley. 1943. The insect inquilines and victims of pitcher plants in North Carolina. Ann. Entomol. Soc. Amer. 36: 128-137. 
ADDITIONAL REFERENCES

other investigators may be interested in all categories of the literature concerning Prosapia bicincta as was the writer. Metcalf (44) thoroughly covers the literature up through 1955. Important references from 1955 to the present are covered in the LITERATURE CITED section of this text. The additional references presented here cover the same period but were not cited in this text.

Allen, L. R. 1966. Coastal bermudagrass for grazing, hay, silage. Clemson Univ. Ext. Ser. Circ. 406.28 p.

Dekle, G. W. 1955. Some 1ychee insects of Florida. Proc. Fla. Hort. Soc. 67: 226-227.

French, J. C. 1965. Spittlebug damage to Coastal bermuda. Univ. Georgia Coop. Ext. Ser. Leaflet No. 28. 1 p.

Genurig, W. G. 1955. Pasture and livestock insects and their control. Univ. Fla. Everglades Sta. Mimeo Rep. 55-8. $17 \mathrm{p}$.

Maxwe11, L. S. 1965. Florida insects, their habits and control. Lewis S. Maxwe11. Tampa, F1a. 120 p.

Olivera B., Dora Elba Lopez. 1967. Taxonomia de las especies que integran el comple jo de la mosca pinta de los pastos (Aeneolamia spp. y Prosapia spp.) en la costa del Golfo de Mexico. Abstract in Proc. 5th Congr. Iiacional Entomo1., Folia Entomol. Mex. (15-16): 10-12.

U.S.D.A. 1956. Coop. Econ. Insect Rep. 6(14): 289.

- 1957. Coop. Econ. Insect Rep. 7(42): 823.

- 1958. Coop. Econ. Insect Rep. 8(6): 94, 97, 99.

- 1959. Coop. Econ. Insect Rep. 9(39): 880. (40): 895. (41): 913.

- 1960. Coof. Econ. Insect Rep. 10(29): 642.

- 1961. Coop. Econ. Insect Rep. 11(48): 886. 
1962. Coop. Econ. Insect Rep. 12(27): 721. (30): 820. (39): 1060. $(40): 1072$.

- 1963. Coop. Econ. Insect Rep. 13(38): 1109. (44): 1289.

- 1964. Coop. Econ. Insect Rep. 14(25): 641. (34): 965. (37): 1044. $(38): 1085 .(40): 1109$.

- 1965. Coop. Econ. Insect Rep. 15(21): 501. (23): 570. (31): 848. (37): $1060,1077 .(39): 1117 .(40): 1136 .(42): 1185 .(43): 1205$. $(44): 1219$.

- 1966. Coop. Econ. Insect Rep. 16(25): 570. (33): 802. (36): 877. (37): 900. (42): 988. (45): 1044. (47): 1079 .

. 1967. Coop. Econ. Insect Rep. 17(26): 560. (37): 849. (41): 922. (43): 956.

- 1968. Coop. Econ. Insect Rep. 18(18): 354. (25): 544. (34): 811.

Velez, Joel Rodriguez, and Fernando Garcia M. del C. 1967. Evaluacion bajo condiciones de campo de insecticidas granulados contra la mosca pinta de los pastos en la region del Golfo. Abstract in Proc. 5th Congr. Nacional Entomol., Folia Entomol. Mex. (15-16): $\overline{9}-10$. 


\section{BIOGRAPHICAL SKETCH}

Ernest Brad Fagan was born on January 2, 1943, at Joplin, Missouri. He graduated from Joplin High School in June, 1960. He entered Joplin Junior College that September and received an Associate of Arts degree in June, 1962. He then attended the University of Missouri and recieved a Bachelor of Science degree with a major in wildife Conservation in February, 1965, and a Master of Science degree with a major in Entomology in February, 1967. From September, 1966, to the present he has been a graduate research assistant in the Department of Entomology at the University of Florida working toward the degree of Doctor of Philosophy. He is a member of the Entomological Society of America, the Florida Entornological Society, the Kansas Entomological Society, the Newel1 Entomological Society (past president 1968-69), and the Phi Sigma Society.

E. Brad Fagan married the former Jimmye Dean Beasley in 1961. They have one son, Bret James Fagan. 
This dissertation was prepared under the direction of the chaiman of the candidate's supervisory committee and has been approved by all members of that committee. It was submitted to the Dean of the College of Agriculture and to the Graduate Council, and was approved as partial fulfillment of the requirements for the degree of Doctor of Philosophy.

Decenber, 1969

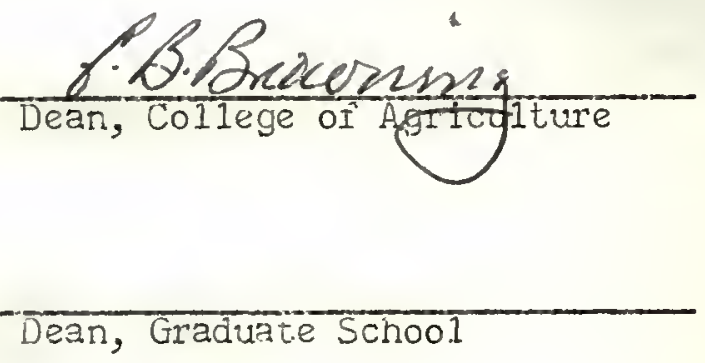

Supervisory Committee:

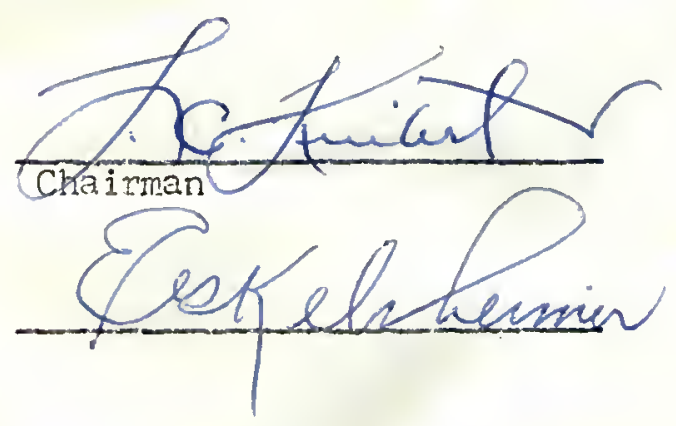

A.B. N-Elinges 


$$
\begin{gathered}
431.1 \\
\text { agri. } \\
\text { Cultural } \\
\text { LHBRART }
\end{gathered}
$$

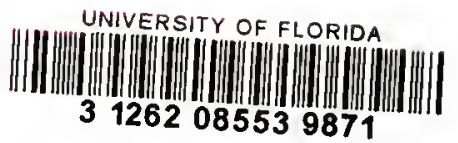

